Andrews University

Digital Commons @ Andrews University

1996

\title{
A Training Program for Grief Ministry for Singapore Seventh-day Adventist Pastors
}

Chor Kiat Sim

Andrews University

Follow this and additional works at: https://digitalcommons.andrews.edu/dmin

Part of the Practical Theology Commons

\section{Recommended Citation}

Sim, Chor Kiat, "A Training Program for Grief Ministry for Singapore Seventh-day Adventist Pastors" (1996). Professional Dissertations DMin. 688.

https://dx.doi.org/10.32597/dmin/688

https://digitalcommons.andrews.edu/dmin/688

This Project Report is brought to you for free and open access by the Graduate Research at Digital Commons @ Andrews University. It has been accepted for inclusion in Professional Dissertations DMin by an authorized administrator of Digital Commons @ Andrews University. For more information, please contact repository@andrews.edu. 


\begin{abstract}
A TRAINING PROGRAM IN GRIEF MINISTRY FOR SINGAPORE SEVENTH-DAY ADVENTIST PASTORS
\end{abstract}

by

Chor-Kiat Sim

Adviser: James J. North, Jr. 


\title{
ABSTRACT OF GRADUATE STUDENT RESEARCH
}

A Project Report

\author{
Andrews University \\ Seventh-day Adventist Theological Seminary
}

\begin{abstract}
Title: A TRAINING PROGRAM IN GRIEF MINISTRY FOR SINGAPORE SEVENTH-DAY ADVENTIST PASTORS
\end{abstract}

Name of researcher: Chor-Kiat Sim

Name and degree of faculty adviser: James J. North, Jr., D.Min.

Date completed: January 1996

Problem

Many Seventh-day Adventist church pastors in Singapore are not trained in grief ministry. This results in some pastors who are insensitive to the grieving. Consequently, theirs and many church members' grief has been unresolved. This study was undertaken to develop a holistic pastoral perspective regarding grief and to compose a training program in grief ministry that will help pastors understand their own grief dynamics and that of their parishioners.

Method

This project attempts to present the principles of grief ministry through the following dimensions: (1) Singapore's need of grief ministry in the midst of socioeconomic development; (2) the study of the images of God in 
the theology of creation, death, and resurrection as they relate to grief according to the Bible; (3) the introduction of some training principles of clinical Pastoral Education (CPE) and other practical resources for pastors in grief ministry; and (4) helping pastors define their roles in personal and corporate grief recovery through reflection and participation in a spiritual retreat.

\section{Conclusion}

The principles in this research will help pastors become more effective and caring in grief ministry. 


\author{
Andrews University \\ Seventh-day Adventist Theological Seminary
}

\begin{abstract}
A TRAINING PROGRAM IN GRIEF MINISTRY FOR SINGAPORE SEVENTH-DAY ADVENTIST PASTORS
\end{abstract}

\author{
A Project Report \\ Presented in Partial Fulfillment \\ of the Requirements for the Degree \\ Doctor of Ministry
}

by

Chor-kiat sim

January 1996 
${ }^{\circ}$ Copyright by Chor-Kiat Sim 1996

All Rights Reserved 


\title{
A TRAINING PROGRAM IN GRIEF MINISTRY FOR \\ SINGAPORE SEVENTH-DAY ADVENTIST PASTORS
}

\author{
A project report \\ presented in partial fulfillment \\ of the requirements for the degree \\ Doctor of Ministry
}

by

Chor-Kiat Sim

APPROVAL BY THE COMMITTEE:
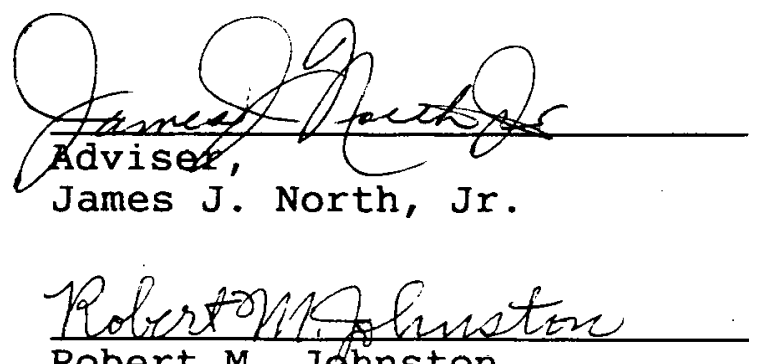

Robert M. Johnston
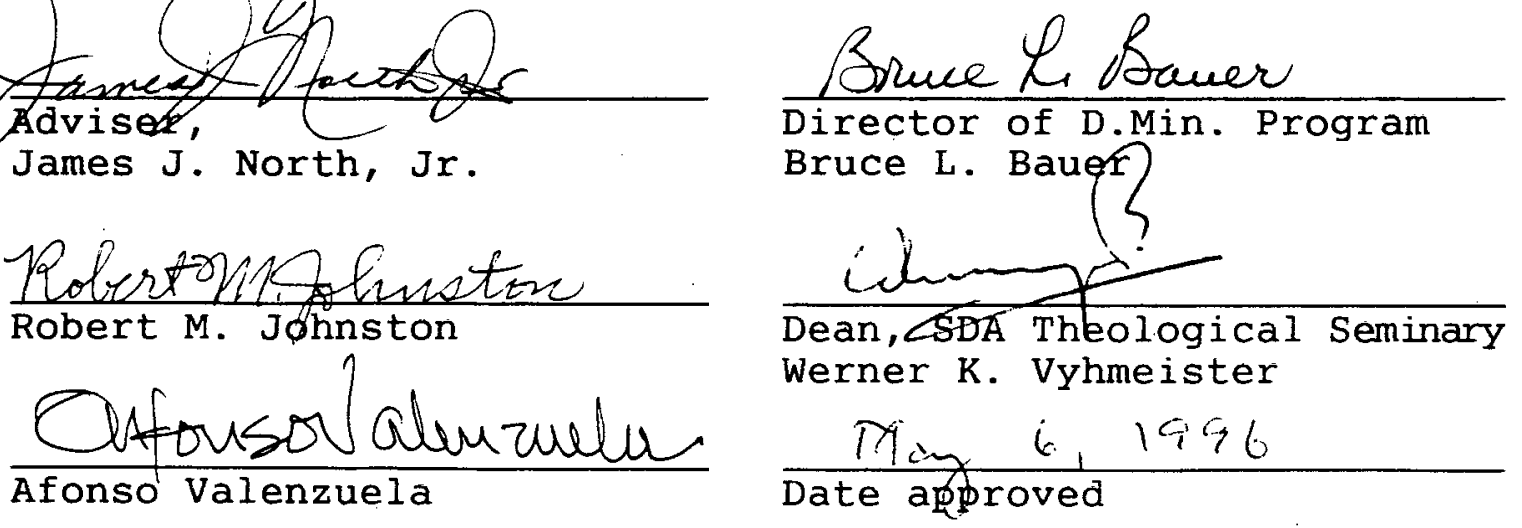
TABLE OF CONTENTS

LIST OF TABLES . . . . . . . . . . . . . . . . vii

ACKNOWLEDGMENTS . . . . . . . . . . . . . . viii

INTRODUCTION . . . . . . . . . . . . . . . 1

Statement of the Project. . . . . . . . . . . 2

Purpose of the Project . . . . . . . . . . . . . 3

Justification of the Project . . . . . . . . . 3

Description of the Project . . . . . . . . . . . . 8

Limitations . . . . . . . . . . . . . . . . 10

Survey of Literature. . . . . . . . . . . . . . . . 11

Definition of Terms . . . . . . . . . . . . 13

Chapter

I. PSYCHO-SOCIOLOGICAL AND MINISTERIAL PROBLEMS

IN MODERN SINGAPORE . . . . . . . . . . . . 19

Introduction . . . . . . . . . . . 19

Brief Demographic Study. . . . . . . . . . 20

Socio-economic and Political Issues. . . . 20

Changing Focus in Economy. . . . . . . . 21

Foreign Policies.......... . . 22

Standard of Living . . . . . . . . . . 23

Older Adult Life............ . 23

Health-care Facilities. . . . . . . . 24

Holistic Tradition . . . . . . . . . 24

Government Support . . . . . . . . . 24

Changing Family Relationships. . . . . . . 25

Preserving Values. . . . . . . . . . 26

Changing Attitudes toward Mourning . . . . 26

Integration of Faith. . . . . . . . . 27

Rituals . . . . . . . . . . . . 27

Contextualization . . . . . . . . . . 28

Presence of the SDA Church . . . . . . . . 29

Brief Historical Background . . . . . . 30

Environmental and Social Changes . . . 32

Older Adult Ministry . . . . . . . . . . 34

Conclusion . . . . . . . . . . . 36 
II. IMAGES OF GOD WITHIN THE CONTEXT OF CREATION, DEATH, RESURRECTION, AND GRIEF • • • • • • •

Introduction . . . . . . . . . . . . • 38

God as Creator at Creation . . . . . . . 39

God and Creation . . . . . . . . . . 39

Creation and Incarnation . . . . . . . 41

God of Creation and Worship. . . . . . 42

Implications . . . . . . . . . . . . . 44

God as Sustainer through Dying and Death . . 44

God's Love Contrasted with Death . . . . 44

God as a Shepherd . . . . . . . . . 45

God's Sustaining Grace . . . . . . . 46

Implications . . . . . . . . . . . 47

Coping with grief. . . . . . . . . 47

Hope in the Second Advent. . . . . . . 48

God as Redeemer in Resurrection . . . . . . 49

God Provides Renewal . . . . . . . . . 49

Christ Is the Resurrection. . . . . . . . 49

God and New Creation . . . . . . . 51

Implications . . . . . . . . . . 52

God as Comforter in Grief . . . . . . . 52

God Who Comforts . . . . . . . . . 52

Christ Comforted His Disciples . . . . . 54

Implications . . . . . . . . . . 56

Conclusion . . . . . . . . . . . . . 56

III. PRACTICAL RESOURCES FOR COPING WITH GRIEF . • • 58

Introduction . . . . . . . . . . . . . 58

Pastors' Roles in Relation to God's Images. 59

Pastoral Role as Preacher...... . . 61

In Sabbath celebration ....... . 61

In sharing of gospel message .. . . . 62

In preaching the resurrection

Pastoral Role as Teacher ....... . 65

of Creator-creation relationships . . 66

of truth about death ....... . . 67

Of the resurrection hope... . . . 69

Pastoral Role as Healer... . . . . . 70

Through mediation . . . . . . . . 70

Through hope........... . . 70

Through health ministry . . . . . 72

Practical Suggestions . . . . . . . . 73

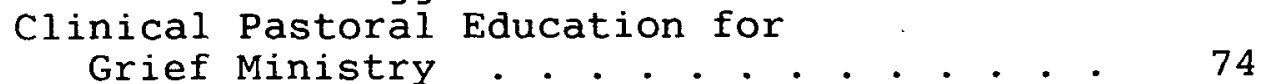

Pastoral-Care Emphasis . . . . . . . 75

Clinical Methods . . . . . . . . . . . 75

Integration of Faith and Ministry . . . . 77

Comparison with the Teaching

Techniques of Christ. . . . . . . 77 
Practical Suggestions . . . . . . . . 78

Cultural Values in the Yin/Yang Concept . . 79

Imageries and Symbols . . . . . . . . 80

A Narrow System Interpretation . . . . 81

Contextualizing Cosmology . . . . . . . 82

Strengthening Family Values . . . . . . . 83

Practical Suggestions . . . . . . . . 85

Development of Self within the Pastoral

Perspective . . . . . . . . . . . . 86

Personal and Spiritual Dimensions . . . 86

Developing Relationships. . . . . . . 87

Integrated Perspective. . . . . . . . . 88

Growth in Pastoral Skills . . . . . . . 89

Communication. . . . . . . . . . 90

Personal gifts... . . . . . . . . 90

Holistic Pastoral Perspective . . . . . 91

Practical Suggestions . . . . . . . . 97

Conclusion . . . . . . . . . . . . . 97

IV. INTERVENTION . . . . . . . . . . . . . . . . . 98

Introduction . . . . . . . . . . . . . 98

Biblical Foundation for Intervention . . . . 99

Intra-personal Dynamics of Intervention . 100

Spiritual aspects. . . . . . . . . 101

Emotional aspects. . . . . . . . . 102

Inter-personal Dynamics of Intervention . 105

Individual response. . . . . . . . . 105

Corporate response . . . . . . . 106

Objectives of Growth Retreat . . . . . . . 108

Integrative Role of the Growth Retreat. . 109

Guidelines . . . . . . . . . . . . 110

Conclusion . . . . . . . . . . . . . . 111

V. SUMMARY AND CONCLUSION . . . . . . . . . . . 112

Summary . . . . . . . . . . . . . 112

Recommendations . . . . . . . . . . . 114

Conclusion . . . . . . . . . . . . . . 115

Personal Postscript . . . . . . . . . . 115

Appendix

A. SDA MISSION STATEMENT . . . . . . . . . . 118

\begin{tabular}{l} 
B. SDA STATEMENTS ON CARING FOR CREATION AND FOR \\
DEATH AND DYING... \\
\hline
\end{tabular}

C. MAPS. . . . . . . . . . . . . . . . 125

D. SAMPLE LETTERS. . . . . . . . . . . . . . . . 128 
E. LETTERS OF NIX AND SAMUTHRAM . . . . . . . . . 132

F. PRE-RETREAT INVENTORY . . . . . . . . . . . . . 135

G. G-R-O-W-T-H SEASONS . . . . . . . . . . . . 141

H. COMPONENTS OF HOLISTIC PERSPECTIVE. . . . . . . 144

I. EIGHT STAGES OF LIFE (Erikson). . . . . . . . . 146

J. ORDER IN EACH SESSION OF RETREAT. . . . . . . . 148

K. CONTENT SUMMARY OF RETREAT. . . . . . . . . . 150

L. SYLLABI OF RETREAT. . . . . . . . . . . . . . 153

M. OBJECITVES OF INVENTORIES, QUESTIONNAIRES, AND STORY-WRITING . . . . . . . . . . . . . . 185

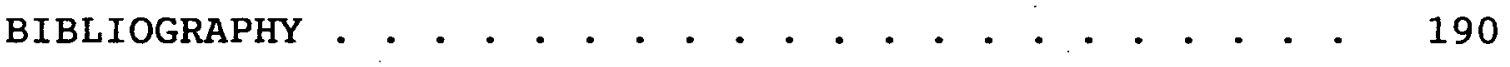

VITA . . . . . . . . . . . . . . . . . 203

vi 


\section{LIST OF TABLES}

1. Singapore SDA Mission's Distinctive 4 Period of Transition . . . . . . . . . .

2. Period of Singapore's Environmental and Moral Changes . . . . . . . . .

3. An Estimate of Senior Members, older Parents of Church Members and Senior Religious Citizens in each church . . . . . . . . .

4. Older Adults Who May be Reached through SDA Institutions . . . . . . . . . . . .

\section{LIST OF ILLUSTRATION}

1. Components of a Holistic Pastoral

Perspective . . . . . . . . . . .

2. Fragmented Dimensions before Grief Work Has Taken Place... . . . . . . . . .

3. Holistic Transformation in dimensions of Grief . • . . . . . . . . . . . . . 


\section{ACKNOWLEDGMENTS}

I thank Dr. C. Raymond Holmes, former director of the Doctor of Ministry program, whose philosophy and spirituality in ministry provided me with a pastoral model. I am grateful for the challenges and encouragements of Dr. James North, seminary chaplain and chairman for my project committee, Dr. Robert Johnston, professor of New Testament, Dr. Bruce L. Bauer, current director of the Doctor of Ministry program, and Dr. Alfonso Valenzuela, professor in counseling and reader. They served as project committee members for my project and provided me with very helpful criticism. Insights from the writings of Dr. Homer L. Jernigan, professor emeritus at Boston University, evaluations from Dr. Jimmy Kijai, professor in Education Research and Statistics, and grief recovery concepts from Elder Larry Yeagley in his Grief Recovery program for the Seventh-day Adventist Church have been very helpful.

My granduncle/mentor, Mr. Sim Yeow-Hwee, has contributed generously to my education and facilitates healing in my grief over the deaths of my late grandparents, parents, and Yinian. My colleagues in ministry, who served with me in my twenty-five years of pastoral service, including four years of administration, have prompted me to deepen my understanding of $l$ ife and relationships. 
My most profound gratitude goes to, Winnie, my wife, who supports me with sacrificial devotion to my doctoral study. My daughters, Gillian, Ginny, and Genny, have been my source of joy.

There are many other prayers and willing hands that contributed to the completion of this Doctor of Ministry project. I thank my Lord for His grace, guidance, and comfort in grief and affirmation in triumph. 


\section{INTRODUCTION}

Pastors all over the world are called in this age of rapid change to provide pastoral care to those who are grieving. In order to be effective in grief ministry, it is essential for them to be trained to identify and to process their own grief. This training will facilitate the development of both their "God-given and God-like qualities."

This research project has been prompted by an absence of such a training in singapore. Perhaps it refiects a human tendency to avoid coping with grief because grieving is such a painful process. This seems to be evidenced by the fact that only twelve out of the thirty-one pastors and church members who signed up actually attended a "Coping with Grief and Loss Seminar."2 This avoidance tendency, coupled with the constant pastoral pressure of a goaloriented church and a Westernized success-driven society, raises the question as to how pastors can be sensitive to those who are grieving.

\footnotetext{
${ }^{1}$ Donna Reilly Williams and JoAnn Sturzl, Grief Ministry (San Jose, CA: Resource Publications, 1992), 89.

${ }^{2} \mathrm{Ki}-\mathrm{P} \bar{l}$ in Lee, "Coping with Grief and Loss Seminar," Adventist Crossroads, July-September 1992, 4.
} 
I am speaking from the perspective of twenty-five years in pastoral ministry. During the last five years (1991-1995), I have experienced grief personally and have observed other SDA pastors struggling through their grieving process. Another Singapore-trained pastor and I are engaged in spiritual pilgrimages at the Andrews University SDA Theological Seminary as well as advanced Clinical Pastoral Education (CPE). We have struggled with grief issues that were never identified clearly before. We have unraveled some of the hidden pain that formal education and our ensuing experiences have not revealed. My friend and former colleague has only recently become more conscious of his father's death of thirty-two years ago. We also have bemoaned the April 1994 murder of Elmo See, another former colleague, while he was actively engaging in his pastoral duties. As a result of reflection on these and other deaths and losses, we have become more aware of our calling to cope with grief as part of our pastoral ministry.

\section{Statement of the Project}

The intent of this research project is to respond to the need for Singapore SDA pastors to become more sure of their pastoral identity in terms of sensitivity to grief. The task of this project is to develop a spiritual retreat as an initial phase of a training program to assist pastors in Singapore to formulate a more effective grief ministry. 


\section{Purpose of the Project}

The purpose of this project report may be seen as threefold: (1) to enable the pastor to establish a theological framework by understanding the images of God in the biblical teachings of creation, death, resurrection, and grief; (2) to integrate the cognitive and affective components of these teachings in a clearer understanding of pastoral roles; and (3) to equip Singapore pastors for more effective grief ministry by engaging them in a spiritual retreat based on the principles of grief ministry. The project thus attempts to blend the "Being," the "Knowing," and the "Doing" of grief ministry."

\section{Justification of the Project}

Grief ministry in pastoral care is best practiced when pastors and laity know the biblical principles and practices of the church related to grief. Through creative methods in grief ministry, viable steps toward a more effective grieving process are facilitated. This study in grief ministry is chosen for the following ten reasons pertinent in the Singapore context:

1. Biblical Study: The SDA Church has historically focused on the state of the dead for evangelistic purposes. Although this is important, for the grieving pastors and

${ }^{1}$ Dwight L. Grubbs, Beginning: Spiritual Formation for Leaders (Lima, OH: Fairway Press, 1994), 12-13. 
parishioners, this doctrine needs to be addressed from a pastoral care point of view.

2. Professional Support: There is a constant challenge to provide professional support to SDA pastors in singapore. In this case, there is a need to increase their sensitivity and skills in ministering to the grieving. They, who are schooled in theology and practical ministry, can be more professionally trained in grief ministry based on biblical principles.

3. Preserving Family Values: The adoption of a more Western, technological, and humanistic lifestyile in Singapore has altered the attitude of Singaporeans toward local traditions such as filial piety. ${ }^{1}$ Such influences have gradually undermined the value systems of families and hinder the traditional intra-family support for the aging, the dying, and those in grief. One way of resisting further deterioration is to train pastors to help families to see grief as a special time for mutual support, to help families set priorities that give family grieving its proper place.

4. Christ-centered Ministry: There is a need to pattern the gospel ministry after the example of christ.

${ }^{1}$ William E. Soothhill, The Analects of Confucius, 2d ed. (New York: Paragon Book Reprint Corp., 1968), 153. Filial piety means to serve parents, to honor them, to care for them in their old age, and to bury them with decorum when they die. In Singapore most deaths are caused by aging. Since grief ministry in Singapore mostly has to do with coping with the process of growing old, both the individuals who are aging and their family members would find support from knowing the dynamics of grief. 
Christ met the needs of the grieving through comforting messages. He said that those who mourn will be comforted (Matt 5:4). $\quad$ Teaching pastors to understand grief on a biblical basis and to increase their sensitivity to the grieving are basic steps in developing a grief ministry program. A Christ-centered ministry is a visible sign of a caring church.

5. Evangelism: Both the Bible and other inspired writings contain references to the witnessing power of suffering and grief. "As the sufferings of Christ flow over into our lives, so also through Christ our comfort overflows" ( 2 Cor 1:5). Ellen G. White, renowned SDA . author, wrote, "The Lord has special grace for the mourner, and its power is to melt hearts, to win souls." ${ }^{2}$ Grief ministry is a unique approach for reaching people who have lost their loved ones, especially older Chinese parents, whose traditional values are rooted in filial piety known as "hsiao"( $)$. $^{3}$ Meaningful Christian rituals can be appreciated by non-Christian families in moments of

${ }^{1}$ All scriptures, except as noted, are quoted from the New International Version.

${ }^{2}$ Elilen $G$. White, Thoughts from the Mount of Blessing (Mountain View, CA: Pacific Press Publishing Association, 1956), 13 .

${ }^{3}$ D. Howard Smith, Chinese Religion (London: Trinity Press, 1968), 25. "Filial piety" or honoring parents and ancestors has a religious connotation. Ancestral worship has dominated China since the Shang Dynasty (1766 B.C.). Though such worship has been neglected in modern Chinese homes, parents still remain the respected authority in most households. 
bereavement. These non-Christian relatives who witness a meaningful service for the deceased may become more receptive to the SDA faith.

6. Personal Needs: The need for pastors and believers to cope with grief, caused by aging and loss, has been reported in Adventist Crossroads, the official newsletter of the SDA Mission of Singapore.' Ultimately, through this process of equipping pastors for grief ministry, churches will receive more pastoral care.

7. Mission: The fundamental beliefs of the SDA Church, based on creation and redemption, advocate grief ministry. Grief ministry requires the biblical understanding of God. The church has the mandate to preach the everlasting gospel to all nations and to worship the Creator (Rev 14:6-7). Preaching the everlasting gospel includes how to glorify God and be more effective agents sensitive to all human concerns, including grief. Ministry to those who grieve over dying and death can be educational to church pastors and members in fulfilling the mission of the Church. ${ }^{2}$ (See

\footnotetext{
${ }^{1} \mathrm{Ki}-\mathrm{pl}$ in Lee, "Self-esteem Seminar," Adventist Crossroads, January-March 1992, 10. Subsequent articles in the same newsletter that expressed such a need are "Coping with Grief and Loss Ministry," July-September, 1992; and "Church Voted for New Direction," April-June, 1994.

${ }^{2}$ [William G. Johnson], editorial, Adventist Review, April $22,1993,7$.
} 
Appendix A.) The prerogative of a caring church is one that carries out support to the grieving through pastoral care.

8. Pastoral Leadership: Pastors, who desire to have an effective pastoral leadership, need to work through their own grief while they help others. Unless pastors are sensitive to their own needs, there will be little progress in pastoral care. The principle of self-awareness for the Corinthian believers was taught by Paul in 2 Cor 13:5, "Examine yourself to see whether you are in the faith; test yourselves." Paul also admonished them on spiritual pride. He said, "So, if you think you are standing firm, be careful that you don't fall!" (1 Cor 10:12). Therefore, in order to equip pastors for grief ministry, it is advisable to begin with humility and self-awareness. ${ }^{2}$

9. Spirituality: There is a need for pastors to understand and be able to show parishioners the relationship between physical death and the daily spiritual death. God is concerned over death. He sent His Son to die in order to

${ }^{1}$ Gottfried Oosterwal, "Adventist Mission Today," in Health Evangelism Study Guide (Siloam Springs, AR: Creation Enterprises International, 1991), 1-17. The caring church is a new self-understanding of the church in response to the powerful opportunities in mission. "The concept centers around the Biblical notion that the church has been called into existence for the purpose of mission; that it exists by mission 'as a fire exists by burning' (Brunner). The mission to which the church is called is nothing else but the mission of Jesus Christ."

${ }^{2}$ Richard J. Foster, Celebration of Discipline (San Francisco: Harper and Row, 1988), 130-131. 
ultimately deliver His creatures from death (2 Pet 3:10). Grief ministry helps believers to understand what it means to die daily spiritually (1 Cor 15:31). Spiritual growth begins as one comprehends the meaning of the cross (Eph $2: 16)$. The cross points people to Christ the Creator as our Redeemer, One "familiar with suffering" (Isa 53:3).

10. Moral Ethics: The study of grief ministry is timely because the General Conference of SDAs published statements on care for the dying in the May, 1993, issue of Ministry Magazine $^{1}$ (see Appendix B). These statements contain an ethical basis for decisions in times of death and dying. The beliefs of SDAs in creation and redemption require guidelines from ethical statements so that pastors who practice pastoral care can find a frame of reference for themselves or for their parishioners in facing grief issues.

\section{Description of the Project}

Grief ministry, in order to be effective, has to integrate theology, education, culture, and personal development. Harris said that the Bible shares some universal values with the Orient in terms of respect to the elderly. ${ }^{2}$ This project takes these biblical and cultural

\footnotetext{
"Editor, "Statement III: Care for God's Creation" and "Statement IV: Care for the Dying," Ministry, May 1993, 24.

$2 \mathrm{~J}$. Gordon Harris, Biblical Perspectives on Aging (Philadelphia: Fortress Press, 1987), 30.
} 
principles of respect to the aging and grieving into consideration.

The four main phases of this research project are:

1. The identification of the problem

2. The exposition of biblical texts about God

3. The exploration of practical resources

4. The understanding of biblical intervention and relationships

5. A proposed spiritual retreat of four sessions.

Summaries of the subsequent chapters of this project report follow.

Chapter 1 focuses on the social and spiritual concerns of the Singapore population. Changes in families, churches, and communities have complicated the grief process.

Examples that help to understand these changes are cited.

Chapter 2 presents a study of the images of God within the context of creation, death, resurrection, and grief. Four of these images related to grief are those of God as Creator, Sustainer, Redeemer, and Comforter. This study provides a theological framework on which to base proposed principles in grief ministry.

Chapter 3 presents some practical resources as follows: 1. SDA pastors' role as articulated within a sound understanding of God's images in creation, death, and resurrection 
2. CPE principles alongside theological education

3. Cultural values in Chinese Yin-Yang concept

4. Personal development of self-image as part of pastoral perspective.

Chapter 4 presents the grief recovery process in the context of a retreat in order to provide time for reflection on:

1. Relationships

2. Process in grief recovery

3. Follow-up through the formation of plans

4. Grief exercises, reflection on their pastoral perspective, formulation of grief ministry plans, and evaluation questionnaires are introduced.

Chapter 5 summarizes the essential points of the project and makes some recommendations for future research in grief ministry.

\section{Limitations}

This project is limited by distance, time, and space. Geographically, Singapore is on the other side of the earth. But the ideas presented are founded on books available in the USA. Theological studies, statistics, and some practical resources relevant to grief ministry are employed to provide essential guidelines in formulating a viable training program. Singaporean SDA pastors who attended Andrews University between 1991 and 1995 were interviewed 
regarding some facts and figures on aging. The statements from the May 1993 issue of Ministry based on the 1992 Annual Council of the General Conference Executive Committee minutes are included for reference, "Care for God's Creation" and "Care for the Dying," but are not elaborated on for the sake of brevity.

\section{Survey of Literature}

The literature on grief comes from a spectrum of disciplines. The study of grief ministry is a conscious attempt to integrate theology, Scripture, education, and CPE with personal development toward the goal of a more holistic pastoral perspective. Bible commentaries and dictionaries, books on systematic theology, Chinese cultural studies, pastoral care, and the writings of Ellen G. White on grief are the main sources.

The writings of Louis Berkhof, ${ }^{1}$ H. Wheeler Robinson, ${ }^{2}$ Millard J. Erickson, ${ }^{3}$ and Oscar Cullmann ${ }^{4}$ provide helpful

\section{${ }^{1}$ Louis Berkhof, Systematic Theology (Grand Rapids:}

Wm. B. Eerdmans Publishing Co., 1976).

${ }^{2} \mathrm{H}$. Wheeler Robinson, The Christian Doctrine of Man (Edinburgh: T. \& T. Clark, 1926).

${ }^{3}$ Millard J. Erickson, Systematic Theology (Grand Rapids: Baker Book House, 1985).

${ }^{4}$ Oscar Cullmann, Immortality of the Soul or Resurrection of the Dead? (New York: Macmilian Company, 1958). 
oncepts of God with reference to the doctrines of creation, death, grief, and resurrection.

The works of Howard J. Clinebell, Jr., ${ }^{1}$ and Homer L. Jernigan ${ }^{2}$ have yielded the principles of pastoral care. The writings of Larry Yeagley, ${ }^{3}$ John Schneider, ${ }^{4}$ and Wayne E. Oates ${ }^{5}$ have provided helpful concepts and techniques.

Ellen G. White provided direction regarding holistic concepts.' Contemporary SDA authors who have integrated theology with practical faith are Samuele Bacchiocchi,' C. Raymond Holmes, ${ }^{8}$ Richard Rice, ${ }^{9}$ and Gerard Damsteegt. ${ }^{10}$

${ }^{1}$ Howard J. Clinebell, Jr., Basic Types of Pastoral Counseling (New York: Abingdon Press, 1966).

${ }^{2}$ Homer L. Jernigan, "Bringing Together Psychology and Theology: Reflection on Ministry to the Bereaved," The Journal of Pastoral Care 30, no. 2 (1976): 88-102.

${ }^{3}$ Larry Yeagley, Grief Recovery (Muskegon, MI : Larry Yeagley, 1984).

"John Schneider, Stress, Loss, and Grief (Baltimore, MD: University Park Press, 1984).

${ }^{5}$ Wayne E. Oates, Pastoral Counseling in Grief and Separation (Philadelphia: Fortress Press, 1980).

${ }^{6}$ Ellen G. White, Education (Mountain View, CA: Pacific Press, 1952).

${ }^{7}$ Samuele Bacchiocchi, Divine Rest for Human Restlessness (Berrien Springs, MI: By the author, 1980).

${ }^{8} \mathrm{C}$. Raymond Holmes, The Last Word (Berrien Springs, MI: Andrews University Press, 1987).

${ }^{9}$ Richard Rice, The Reign of God (Berrien Springs, MI: Andrews University Press, 1985).

${ }^{10} \mathrm{P}$. G. Damsteegt, Seventh-day Adventists Believe... (Hagerstown, MD: Review and Herald Publishing Association, 1988 ). 
Their writings have helped to relate the doctrines of the church to grief ministry. The changes in pastoral ministry in Singapore have been gleaned from the observations of Keith Hinton, who taught at Singapore Bible College. His book identifies the training needs of pastors in Singapore. ${ }^{1}$

This research project also consulted articles from the following periodicals: Ministry, Adventist Review, Pastoral Psychology, Journal of Religion in Disability and Rehabilitation, Journal of Psychosomatic Research, and Journal of Clinical Pastoral Care. Computerized statistical records and cassette tapes on grief are also referred to.

\section{Definition of Terms}

Some terms from pastoral care; Chinese concepts, and Malay expressions are defined as follows:

Grief ministry is a process whereby pastors or caregivers assist the grieving ones to find meaning and healing from losses. The general aspects of ministry to the grieving include the following: empathy, communication, Iistening, and prayer." Grief ministry also assists the grievers to find spiritual meaning in times of loss.

\footnotetext{
${ }^{1}$ Keith Hinton, Growing Churches--Sinqapore Style (Singapore: Hiap Seng Press, 1985).

${ }^{2}$ Williams and Sturzl, 89 .
} 
Grief is the intense emotion that flaws life when a person's inner security system is shattered by an acute loss, usually associated with the death of someone important in one's life.' It is defined as

the complex interaction of affective, cognitive, physiological, and behavioral responses to the loss by any means of a person, place, thing, activity, status, bodily organ, etc., with whom (or which) a person has identified, who (or which) has become a significant part of an individual's own self. ${ }^{2}$

A Greek (Gr.) word for grief is penthos, which means "sorrow, or mourning" (John 16:6, 20, 21), "annoyance," and "affliction" $(2 \operatorname{Cor} 7: 10) .^{3}$ A "bewildering cluster of ordinary human emotions" 4 arises in response to a significant loss, intensified and complicated by the relationship to the person, or the object, lost.

Grieving Process is a response process of a person to a loss. Such a process is normal and healthy. However, it can also be pathological and unhealthy if the coping process

${ }^{1}$ Edgar N. Jackson, "Grief," in Concerning Death: A Practical Guide for the Living (Boston: Beacon Press, 1974), 2 .

${ }^{2}$ D. K. Switzer, "Grief and Loss," Dictionary of Pastoral Care and Counseling (Nashville: Abingdon Press, 1990), 472.

${ }^{3}$ Joseph Henry Thayer, "Lupe," Greek-English Lexicon of the New Testament (Chicago: American Book Company, 1881), 383 .

${ }^{4}$ Kenneth R. Mitchell and Herbert Anderson, All the Losses, All Our Griefs (Philadelphia: Westminster Press, 1983), 54 . 
is misdirected, abridged, or avoided. ${ }^{1}$ The griever usually experiences stages of emotional upheavals. Stages of grief are identified as denial, bargaining, anger, depression, and acceptance. ${ }^{2}$

Image refers to the result of reflecting what is God like. ${ }^{3}$ The references about human beings created in the image of God (Gen 2:1-3) and Christ having the image of God (Col 1:5-2) are such examples. Image, in Gr. eikon, refers to "similitude" or "likeness" (Col 1:15; 3:10). "Paul declares that the Christian is renewed 'after the image [eikon] of him that created men." "It is the visible manifestation of the invisible God through the mind. Sometimes, "image" takes the plural form "images," because more than one image is described, such as the various resemblances of God in the Bible related with pastoral identity (see p. 39 below).

Relationship with God in grief ministry refers to one's understanding of and sense of closeness with/or alienation from God as the Creator, the Lord of Life, and the Leader of Human Destiny. The personal relationships between God and

\footnotetext{
${ }^{1}$ Gary R. Collins, Christian Counseling-A Comprehensive Guide (Dallas: Word Publishing, 1988), 346.

${ }^{2}$ Elizabeth Kubler-Ross, on Death and Dying (New York: Macmillan Publishing Co., 1973), ix.

${ }^{3}$ Sinclair B. Ferguson and David F. Wright, "Images of God," New Dictionary of Theology (1978): 428.

"Images," SDA Bible Commentary, ed. F. D. Nichol (Washington, DC: Review and Herald Publishing Association, 1980), $7: 191$.
} 
humankind can give meaning and power to persons who are grieving, as well as to the care-givers. This relationship can also be flawed and unhealthy.

Culture refers to the national ethnic and social contexts where grief ministry is conducted. Such differences are to be respected.

Clinical Pastoral Education (CPE) is an educational model of ministry in which the primary learning comes from experiencing people. It is

a method developing personal and professional growth in ministry, a distinctive feature of which is practical experience of ministry under supervision, normally but not always in a hospital setting.

'Jernigan, "Bring Together Psychology and Theology," 97. "Cross-cultural studies suggest that in the face of death bereaved persons need a framework of beliefs and values to which they can relate their questions about the meaning of this particular death. They need ways to ritualize and symbolize the loss which can be shared meaningfully with others. They need dependable patterns for working through the experience of loss and establishing new kinds of relationships with the deceased. They need opportunities for renewing their ties with family and friends and the community in which they live. In most cultures these needs are met by the particular 'community' or group to which the bereaved family belong" (ibid.).

${ }^{2}$ David Lyall, "Clinical Pastoral Education," $\underline{A}$ Dictionary of Pastoral Care (1987), 36. "(CPE) has its roots in the United States, early important figures being Richard Cabot, a physician, and Anton Boisen, Congregationalist minister. In 1925 Richard Cabot, president of the Council for Clinical Training of Theological students, who had earlier developed a 'casemethod' approach for teaching medical students, wrote a paper, 'A Plea for a Clinical Year in the Course of Theological Study', advocating a similar approach" (ibid.). 
Yin-Yang refers to complementary and dualistic components of nature in the view of Chinese culture. YinYang is a concept that refers to the "harmonious elements pertaining" to life and nature. ${ }^{1}$ The $\underline{\text { in }}$ and the Yang are distinctive and yet exist together. The Chinese have a broad view that refers to an "interior harmony" which manifests itself in extensive meanings. The $\underline{Y}$ in and the Yang interact to determine good health, favorable weather, the mystery of the universe, and family happiness. ${ }^{2}$ The $\underline{\text { Yin }}$ is more receptive, while the Yang is more assertive. Yin is the dark side, while Yang is the bright side. Together, $\underline{\text { Yin }}$ and Yang describe "complementarity. ${ }^{3}$

Tumasik is a the name given to ancient Singapore by the Malays, its original natives.

Padang is a Malay word for green field, or a large field. Singaporeans cherish such fields because traditionally they have gathered in these locations to conduct public meetings. However, modern air-conditioned auditoriums have replaced the fields as the venues for such gatherings.

Holistic is used to describe the human being as whole, i.e., consisting of spiritual, mental, social, and physical dimensions. In this project, the spiritual dimension

\footnotetext{
${ }^{1}$ Smith, 99 .

${ }^{2}$ Ibid.

${ }^{3}$ Carolyn Gratton, The Art of Spiritual Guidance (New York: Crossroad Publishing Company, 1993), 3.
} 
consists of theology and scripture, the mental dimension of education and personal development, with the social dimension of culture and relationships. The physical dimension has been excluded from this project to enhance focus on the subject. Moreover, pastors are not primarycare agents in its maintenance.

Pastoral Perspective has been regarded by Jernigan as an essential part of a pastor's career development that involves his/her total professional life. ${ }^{1}$ In this study, pastoral perspective is an integration of the essential components of pastoral ministry such as theology, biblical understanding, education, personal development, culture, and relationships.

${ }^{1}$ Homer L. Jernigan, "Preface to a Research Project in Pastoral Counseling," The Journal of Pastoral Care 35, no. 2 $(1981): 78$. 
CHAPTER 1

PSYCHO-SOCIOLOGICAL AND MINISTERIAL PROBLEMS

IN MODERN SINGAPORE

\section{Introduction}

Singapore, the crossroads of Asia, is one of the cosmopolitan cities in the world. It is a strategic location for commerce as well as for communicating the gospel to other parts of the Asian Pacific region. The Singaporeans have undergone frequent changes in their expansion of land area, urbanization, politics, moral beliefs, and socio-economic responsibilities.

Singapore is located in the center of Southeast Asia, one degree north of the equator. (See map in Appendix C.) It is one of the smallest countries in the world with a land area of 244 square miles. Its temperature ranges from 75 degrees to 87 degrees Fahrenheit throughout the year.

Singapore is an island of change. It became an independent island nation, separated from the Malayan Peninsula, on August 9, $1965 .^{1}$ Since then it has been declared a self-governed sovereign nation. No landmass in the world can have changed its shape and contours as dramatically as Singapore in the 1990 s because most of its

\footnotetext{
${ }^{1}$ Hinton, 1 .
} 
beaches have surrendered to reclaimed shorelines and rivers to freshwater reservoirs. Singapore, formerly known as Tumasik, is an island of surprise, where colonial buildings, emerald Padang, and modern-day high-rises that rival Manhattan..$^{1}$ In the last three decades, old landmarks have been replaced by new modern buildings and skyscrapers.

\section{Brief Demographic Study}

The population of Singapore in 1995 was approaching 3,000,000. Seventy-seven percent of Singaporeans are Chinese, another $14 \%$ are Malays, $10 \%$ are Indians and other ethnic minorities. The death rate was 13,500 deaths per year in the 1980 s. It has been reported that there were over 16,000 deaths in $1991 .^{2}$ These statistics indicate that, in a little more than a decade, the death rate rose by 2,500 deaths.

\section{Socio-economic and Political Issues}

Since its independence in 1965, Singapore's political leaders, Mr. Lee Kuan Yew (1965-1991) and his colleagues, grappled with unexpected changes and moved towards political independence. This sudden change, instead of bringing discouragement, spurred Singapore's progress. It provided the population with the needed challenge for survival in politically turbulent Southeast Asia. The Chinese, the

${ }^{1}$ I an Lloyd and Irene Hoe, Singapore from the Air (Singapore: Times Press, 1985), 8-11.

${ }^{2}$ World Journal, April 1992, 15. 
Singaporean majority, with Malays, Indians and Eurasians, each contributing according to their abilities, together rose to meet the needs brought about by rapid development and facilitated growth. The challenges brought the best out of the Singaporeans.

Singapore's rapid development also resulted in changes in human lives. Consequently, the ministry of culture emphasized the need to preserve the moral values of each culture in order to succeed.

\section{Changing Focus in Economy}

Singapore has a strategic role in Asia and in terms of commerce and diplomacy with other parts of the world, especially the west." It has to remain "one or two steps ahead of its neighbors." $\mathrm{Mr}$. Lee Kuan Yew, the former Prime Minister, declared, "As long as the balance of geopolitical forces in the South, and South-east Asia remain as they are, Singapore's strategic value will continue undiminished." ${ }^{3}$ Moreover, some wise decisions were made. One of the policies was that "the government has thus officially discouraged the further expansions of such

${ }^{1}$ Dick Wilson, The Future Role of Singapore (New York: Oxford University Press, 1972), 108.

${ }^{2}$ Ibid.

${ }^{3}$ Ibid. 
labor-intensive industries as textiles and the cheaper end of the electronics industry."

From the pre-independent era in the early 1960s, Singapore moved ahead cautiously in its economic policies. It was primarily challenged with survival because of its limited resources. It capitalized on such assets as efficient working forces. Singapore's power in the world's economy has been growing. Its credibility is well known around the world.

\section{Foreign Policies}

The foreign policy of Singapore gives primary emphasis to economic self-interest. Its merchants have not been threatened by international boycotts of foreign governments on ideological or political grounds. Singapore has expanded its economic development by selling its expertise in manufacturing and by marketing its commercial services of all kinds, and it "is still necessary for the island to be open to all comers as far as trade is concerned."

Therefore, Singapore has gained popularity internationally because of its openness and evenhandedness.

\footnotetext{
${ }^{1}$ Ibid., 109.

'Ibid., 108. Because of the terms of the contract that agrees to return Hong Kong to China in July 1, 1997, those Chinese who possess capital and specialties have immigrated to Singapore. In 1992, many Filipino Chinese moved to Singapore due to social discrimination in the Philippines.
} 
Standard of Living

After Japan, Singapore has the second highest standard of living in Asia. The resulting high cost of living imposes more than economic problems on its family units. Materialism has increased in recent years. This secular trend affects attempts in building community, especially when families are caught up in the quest for a modern style of living. ${ }^{3}$

\section{Older Adult Life}

Psychosocial problems created by modernization are common in many adult lives. There are many psychosocial dynamics issues. For instance,

adults face the loss of aging parents, a job change or retirement, children having problems or leaving home, marital difficulties or even divorce, an aging or ill body, financial problems, and especially the mid-life crisis question Gandhi asked, 'What do I really have to pass on? ${ }^{2}$

Unless answers are found to these profound questions, loss will be the end and the people will be doomed to despair. The majority of the elderly die of old age, while some die of illnesses--mainly cardiac, oncological, and pulmonary diseases. Only a few die from accidents and crime. Singapore is a safe city to live in. The average of thirty-seven deaths per day ${ }^{3}$ is due mainly to aging.

\section{${ }^{3}$ Ibid.}

${ }^{2}$ Matthew Linn, Sheila Fabricant, and Dennis Linn, Healing the Eight Stages of Life (New York: Paulist Press, 1987), 185 .

${ }^{3} \mathrm{PC}$ Globe, Tempe, AZ, 1992. 
Health-care Facilities

More hospices and many nursing homes have been established to house the elderly and the dying. The existence of these institutions indicates changing family values and the impact of modernization on society. Children of aged parents are relinquishing the care of the older adults to nursing institutions. Caring for the aged used to be the concern of individual families, but it is now shared with the government.

Holistic Tradition

Some Singaporeans choose to retire at home to experience the natural and traditional process of aging. Others enjoy longevity which exceeds the psalmist's estimate of the "three score and ten" year life span (Ps 90:10). This is thought to be the product of Chinese lifestyle traditions: (1) holistic concepts along with enriching moral beliefs lend themselves to strong bodies and sound minds; and (2) the practice of the health principles of meditation and exercise. The elderly live actively in the year-round fair weather.

\section{Government Support}

Practical projects like health care institutions for the aged and parks are sponsored by the Singapore Government to support the terminally ill, the handicapped, and the aging. The challenge of change in Singapore is also 
met through community-run institutions, such as nursing homes and senior citizens clubs.' A large government department called the Ministry of Community Development has been designated for this purpose of community building.

\section{Changing Family Relationships}

The eroding of traditional family values due to materialism needs to be faced intelligently. This imposes challenges to leaders in Singapore's multiracial community. Pastors are not excluded from serving as leaders in the preservation of the moral standards of the nation.

Singapore has placed productivity as the foremost objective in national development. There are complex issues in facing the challenges of a growing population with limited space. One of these issues is the care of older adults who, in spite of strong traditional values, are viewed by some as burdensome and problematic. For generations, the Chinese have maintained filial piety as taught by the Chinese philosopher Confucius. But that is changing:

We all have often heard it said that we are a young population with more than half our people under twentyone years of age. All this is quite true. Yet, for quite a long time, there has been an acute social problem of old people, a problem which has not received the attention that it deserves. ${ }^{2}$

${ }^{1}$ James Wong, Singapore--A Church in the Midst of Social Changes (Singapore: Church Growth Study Center, 1973), 3-4.

${ }^{2}$ Keng Swee Goh, The Economics of Modernization and other Essays (Singapore: Shing Loong Press, 1972), 158. 
To counter this trend, the government sponsors community centers and clubs with a wide range of recreational activities for older persons, from talent shows to tours. Still, a large number of sons and daughters maintain their family traditions in caring for the older persons at home. ${ }^{1}$

In contrast to those who adhere to tradition, others, who have become affluent, have grown careless towards the older adults. Instances of a lack of respect for the elderly have been demonstrated in caring for the aged, such as the reluctance of young adults to own apartments nearer to their aging parents. ${ }^{2}$

\section{Preserving Values}

To prevent further erosion of traditional virtues, Singapore has engaged in a Courtesy Campaign, which includes showing respect for the elderly. Furthermore, social organizations and churches are working cooperatively with the government to ensure that the elderly are cared for.

\section{Changing Attitudes toward Mourning}

Grieving over the deceased is central in the varied cultures and religions of Singapore, particularly in the

${ }^{1}$ Peter S. J. Chen, Eddie C. Y. Kuo, and Betty Janice Chung, The Dilemma of Parenthood (Singapore: Koon Wah Printing, 1982), 111 .

${ }^{2}$ Straits Times, August 30, 1995, 18 . 
ancestral worship of the Chinese. The Chinese way of handling grief is more expressive and elaborate than that of the West. The bereaved ones express their anger and sorrow much more audibly (e.g., by wailing). In recent years, some have tended to grieve in less intense ways.

Singaporeans have tended to shorten the traditional month-long period of mourning to weeks and days. Presently, most of the dead are cremated, which is followed by a brief ritual. This new way of handing the remains of the deceased moves the griever quickly back into the demands of life but provides less time for the grieving process.

\section{Integration of Faith}

When younger persons become Christians they sometimes attempt to simplify the grieving process in some Western way. Attempts by Christian Singaporeans to pray to God instead of to the deceased, as tradition has required, are met with resistance, protest, and even persecution from family members who do not understand biblical teachings on worship. How can church leaders seek to integrate faith with the Asian way of grieving in the face of Westernization? Are Christians encouraging traditional respect and care for the older adults? How can the biblical teaching of honoring parents (Exod 20:12) be applied here?

\section{Rituals}

Handling death and bereavement is a big business in Singapore. There are specific places where the bereaved 
ones can obtain such necessary materials as candles for worship and mourning clothes. Street vendors and shops are devoted to selling articles used for various rituals. As modern technology influences Singaporeans, some become careless toward the observance of religious rituals. Such carelessness can be traced to the change of attitude in this Westernized society. Helpful rituals of gathering in support groups similar to the "wake" are exhibited when neighbors come to comfort the bereaving.

\section{Contextualization}

Besides becoming more sensitive to older adults in the family, Christians should express love to them in ways that can win them to Christ. Pastors should recognize that

the powerful contextual forces that operated to retard church growth in the early history of the colony [Singapore] have now given place to a new set of contextual factors which are overwhelmingly conducive to growth.1

For example, wealth was a measure of achievement. Success has been replaced by status and higher education. ${ }^{2}$ Educational pursuits provide opportunities for churches to be active in career guidance and counselling centers. In this process of developing counseling centers, Christian counseling, which includes bereavement and crisis counselling, has also developed. This need for guidance provides an excellent opportunity for the church. In spite

\footnotetext{
${ }^{1}$ Hinton, 28 .

${ }^{2}$ Ibid., 33 .
} 
of Singapore's changing needs from a more communal to an individualistic society, there are some areas, such as pastoral care, that can be improved. Since the church plays an important role in pastoral care, a brief review of its history in Singapore is called for.

\section{Presence of the SDA Church}

A view of the history of the SDA Church in Singapore, one of the established churches with over a century of history, is vital to understanding the changes that have occurred. The first SDA missionary to arrive in Singapore was Abram LaRue, a self-supporting literature evangelist from America. He visited Singapore in the late 1890 s and died in 1903. Subsequent to his preaching of the Second Advent message, churches were planted and organized. Following the blueprint of the pioneers, educational and health institutions were established.

The SDA Church in Singapore has faced many challenges in the twentieth century because its nation has undergone economic and political crises such as depressions, World War II, civil disputes, quest for independence, and construction program. The nation experienced the trauma of the Japanese

${ }^{1}$ Gil G. Fernandez, Light Dawns over Asia (Cavite, Philippines: International Institute of Adventist Studies, $1990), 198$. 
Occupation in the 1950s, racial riots, and communist infiltration in the early 1960 s. $^{1}$ It only enjoyed peace after its claim to sovereignty and independence from Malaysia on August 9, 1965.

The church witnessed its climax in soul-winning in the late 1960 s before affluence, such as the use of televisions, was introduced. The SDA churches of this island nation were organized into a local mission on November 26,1987 , when I was elected by the Southeast Asia Union as its secretarytreasurer. In such formative and transitional stages, pangs of growth and changes had to be reckoned with. There also have been periodic emphases on revival and evangelism towards growth by church leaders since the SDA Church's beginning .

In the last decade (1984-1994), church members have faced many changes. These changes, created by the nation's socio-economic growth and an affluent lifestyle, have influenced some to depreciate family values and spiritual concerns.

\section{Brief Historical Background}

Changes have also occurred in the church before and after the formation of the SDA Mission of Singapore in November of 1987. The period between 1970 and 1987 was another time of growth and transition for the SDA Churches

\footnotetext{
${ }^{1}$ Hinton, $14,19,23$, and 24 .
} 
in Singapore. From 1973 to 1979, youthful singaporeans in the Seventh-day Adventist Church were encouraged to prepare themselves for the gospel ministry. Many completed undergraduate theological studies at Southeast Asia Union College (SAUC) and entered into ministerial internships in the early 1970s. As a result, seven local pastors were ordained for the ministry at SAUC Church on January 8, 1977. This has been followed by a period of enriching experience for the ordained pastors.

From 1977 to 1979 , the ordained pastors actively assumed their various functions. From 1980 to 1987 , the local pastors proved to be effective ministerial leaders. Leadership positions were entrusted to them. At that time the SDA churches in Singapore were planning to achieve autonomy from the West Malaysia-Singapore Mission. The process of separation was known as bifurcation. From 19881994, the SDA Mission of Singapore underwent its initial formative stage. The formation of the SDA Mission of Singapore has resulted in transitions, such as leadership and structural changes. (See table 1.) These transitions require the support of the members to adapt to different leadership styles, which varied from more task-oriented to people-centered emphases. Moreover, the SDA Mission of Singapore is moving from a Union-directed organization to a more democratic conference structure in which the members of the church constituency elect their leaders. These changes contribute to transitions that bring grief. 
TABLE 1

SINGAPORE SDA MISSION'S DISTINCTIVE

PERIODS OF TRANSITION

Period Description

1973-79 Internship of local pastors which led to ordination and increased responsibilities

1980-86 Active participation of local pastors in parish ministry and departmental work during this transitional period

1987-94 Mission formation - period of beginnings

1995-97 Plan for conference status formation and older adult ministry laid

Source: Part of Table 1 contributed by Wann M. Fanwar, "Update on Ministries Coordinating Committee," Adventist Cross Roads, July-September, 1994, 2 .

\section{Environmental and Social Changes}

From 1973 onwards, Singapore has undergone urbanization, the rapid replacing of older buildings with new ones and by acquisition of modern equipment for communication. These fundamental changes have been accompanied by emphasis on racial and religious harmony. In the 1980s more extensive urbanization took place to meet the needs of Singapore's growing economy and population. These changes brought the realization of the importance of moral values in nation building.

From 1987-94 Confucian ethics were advocated for community development. The Singapore government attempted 
to inculcate Confucian ethics for the sake of community growth. However, in the early 1990s there was an eroding of Confucianism. This erosion of Confucianism, due to modernization in the 1970s, resulted in the gradual breaking down of family values and community spirit. This coincided with the phasing out of religion in schools. ${ }^{1}$ (See table 2.)

TABLE 2

PERIOD OF SINGAPORE'S ENVIRONMENTAL AND MORAL CHANGES

Period Description

1970-79 Urbanization

1980-86 Extensive urbanization and realization of the importance of moral values in national building

1987-94 Confucian ethics advocated for community growth Eroding of Confucianism (coincides with phasing out of religion in schools)

Source: Part of Table 2 contributed by Patrick Johnstone, Operation World (Grand Rapids: Zondervan Publishing House, 1993), 487.

Environmental and moral changes have affected the evangelistic program of the church. Leaders, during the second triennium of the SDA Mission of Singapore (SAM) held from March 30-31, 1991, noted that the public had been

\footnotetext{
${ }^{1}$ Patrick Johnstone, Operation World (Grand Rapids: Zondervan Publishing House, 1993), 487.
} 
reluctant to attend traditional evangelistic meetings that lasted continuously for a month. Instead, shorter meetings like seminars were recommended. There also were plans to meet the felt needs of the people with such media as health lectures or stress management, before presenting the message. The delegates to the third triennium of SAM held from April 8-10, 1994, also recommended a ministry to the older adults. ${ }^{1}$ Training on intra-personal dynamics ${ }^{2}$ would also be advantageous in preparing pastors for older adult ministry.

\section{older Adult Ministry}

The aging population provides many opportunities for grief ministry among the churches and institutions (see tables 3 and 4 ). The churches and community centers need to organize more support groups to assist the grieving.

Changes in the society have also influenced the SDA Church. Besides the older adults in the church who need care, there are others in the community to reach.

An estimate of senior members, older parents of church members, and senior religious citizens, who belong to a religious organization, in each church district in singapore is presented in Table 3, which shows the potential of ministry to the elderly by the congregations.

${ }^{1}$ [John K. E. Tan], editorial, "Church Votes for New Direction," Adventist Crossroads, April-June 1994, 4.

${ }^{2}$ Erik Erikson, The Life Cycle Completed (New York: W. W. Norton, 1982), 32-33. 
TABLE 3

AN ESTIMATE OF SENIOR MEMBERS, OLDER PARENTS OF CHURCH MEMBERS AND SENIOR RELIGIOUS CITIZENS IN EACH CHURCH DISTRICT ${ }^{1}$

\begin{tabular}{|c|c|c|c|c|}
\hline Church & $\begin{array}{l}\text { Senior } \\
\text { Members }\end{array}$ & $\begin{array}{l}\text { Older Parents } \\
\text { of Members }\end{array}$ & $\begin{array}{l}\text { Senior } \\
\text { Religious } \\
\text { Citizens }\end{array}$ & District \\
\hline Balestier & 20 & 200 & 15,000 & $\begin{array}{l}\text { T. Payoh/ } \\
\text { Whampoa }\end{array}$ \\
\hline Chuan Hoe & 2 & 50 & 20,000 & $\begin{array}{l}\text { Yishun/ } \\
\text { Woodlands }\end{array}$ \\
\hline Dunman & 11 & 50 & 17,000 & $\begin{array}{l}\text { Katong/ } \\
\text { Bedok }\end{array}$ \\
\hline $\begin{array}{l}\text { Jurong } \\
\text { English }\end{array}$ & 4 & 75 & 15,000 & Jurong E. \\
\hline $\begin{array}{l}\text { Jurong } \\
\text { Chinese }\end{array}$ & 7 & 55 & 16,000 & Jurong $\mathrm{w}$. \\
\hline $\begin{array}{l}\text { Southeast } \\
\text { Asia Union }\end{array}$ & 22 & 150 & 17,000 & $\begin{array}{l}\text { Serangoon } \\
\text { Ponggol }\end{array}$ \\
\hline $\begin{array}{l}\text { Thomson } \\
\text { Chinese }\end{array}$ & 50 & 200 & 20,000 & $\begin{array}{l}\text { Thomson/ } \\
\text { Sembawang }\end{array}$ \\
\hline Total & 116 & 780 & 120,000 & \\
\hline
\end{tabular}

Note: These statistics were verified by Matthew Yuen. As a chairman of the Adventist Home for the Elderly for the last two decades, he is an authority on this.

1 Refers to baptized members (age 65 or older) and older parents on members.

2 Refers to older adults (age 65 or older) who believe in God whether they belong to a Christian church or other Asian faith, such as Buddhism or Hinduism. 
TABLE 4

OLDER ADULTS WHO MAY BE REACHED THROUGH SDA INSTITUTIONS

Institution

Number

San Yu High School 300

Seventh-day Adventist School 500

Adventist Child Development Center 100

Seventh-day Adventist Kindergarten 300

Youngberg Adventist Hospital 50

Adventist Home for the Elderly 75

Newstart Program 550

Total

2,075

Note: These statistics are provided by Matthew Yuen, Singapore SDA Mission president.

Table 4 shows opportunities for pastors to reach Singapore's families through ministry to older adults. old age often brings more grief than the younger stages in a person's life. This contextual analysis may help in developing responses to the aging and grief.

\section{Conclusion}

In view of the rapid changes in Singapore and the SDA Church, some of the problems created due to the lack of training in grief ministry have been identified:

1. Some pastors are unaware of their own grief and that of others. 
2. There are pressures in the church bureaucracy that may complicate the stress that pastors already have in their pastoral work.

3. There is a loss of respect for Chinese traditions such as "filial piety." Thus an older adult ministry to those above sixty-five years of age has been gradually neglected. However, the church has only recently recognized the validity of ministry to the older adults.

4. The church is influenced by Westernization and the technological era.

Some of the suggested solutions in this project are recommended during the spiritual retreat. Therefore, a study on the images of God within the context of creation, death, resurrection, and grief that provides the fundamental principles for a grief ministry for pastors is presented in chapter 2 . 
CHAPTER II

\section{IMAGES OF GOD WITHIN THE CONTEXT OF CREATION, DEATH, RESURRECTION, AND GRIEF}

\section{Introduction}

A theological framework upon which to articulate grief ministry is critical for pastors. ${ }^{1}$ It provides a biblical foundation from which ministers can justifiably operate when addressing the issue of grief. This chapter builds its theological framework around the normative images of God, ${ }^{2}$ not only because these are fundamental in the formation of pastoral identity, ${ }^{3}$ but also because the Chinese language and culture, so vividly present in Singapore, use imagery and symbols. This chapter attempts, therefore, to explore

"Jernigan, "Preface to a Research Project," 97. Jernigan is founder of the Clinical Pastoral Care Committee in Singapore and has done extensive research on grief in the Asian context.

${ }^{2}$ E. E. Thornton, "Identity, Pastoral," Dictionary of Pastoral Care and Counseling (1990), 567. "Normative images" means views of God as commonly perceived among Christians.

${ }^{3}$ In Col 1:13-20, Paul related the images of God as Creator and Redeemer with the work of reconciliation. Pastoral ministry requires such fundamental images and influence. In John 14:9, Christ Himself claimed to be God's expressed image. V. Norskov Olsen states, "All that God has is personified in Jesus," Man, the Image of God

(Hagerstown, MD: Review and Herald Publishing Association, $1988), 171$. 
the theological framework fundamental to pastoral identity, based on images of God as the Creator, Sustainer, Redeemer, and Comforter $(\operatorname{Col} 1: 21-23) .^{1}$

This chapter analyzes the themes of creation, death, resurrection, and grief by: (1) summarizing the main biblical content; and (2) drawing implications applicable to Singaporean culture based on the following roles of God: (a) God as Creator at Creation (Gen 1:1, 26-29, 2:7; Col 1:1016; Rev 14:6); (b) God as Sustainer through Dying and Death (Gen 2:16-17; Ps 23; Rom 5:17); (c) God as Redeemer in Resurrection (Ps 104:29-30; John 11:1-45; Phil 3:10-11; Rev 21:1-4); and (d) God as Comforter in Grief (Matt 5:4; John $14: 16 ; \operatorname{Rev} 22: 14)$.

Relevant pastoral principles for grief ministry are highlighted at the conclusion of this chapter.

\section{God as Creator at Creation}

\section{God and Creation}

The image of God as Creator at creation (Gen $1: 1$ ) is central to the theological framework of grief ministry. Erickson, speaking of creation, states, "The creative work of God plays a prominent role in the biblical presentation

\footnotetext{
${ }^{1}$ H. Richard Niebuhr, Daniel Day Williams, and James M. Gustafson, The Advancement of Theological Education (New York: Harper \& Brothers, Publishers, 1957), 94.
} 
of God." Indeed, God's will plays an important role in human events. At creation, God demonstrated His prominence intelligently and personally in a twofold process: (1) God's true majesty in planning to make man and woman in the divine image and blessing them (Gen $1: 26-28) i^{2}$ and (2) God's condescension to make man from the dust of the ground and breathe into his nostrils the breath of life to become a "living being" (Gen 2:7). Commenting on the creation of humankind and the combination of dust and divine breath, Berkhof says,

The twofold nature of man is clearly asserted, and their teaching is corroborated by other passages of scripture, such as, Eccl. 12:7; Matt. 10:28; Luke 8:55; I I Cor. 5:1-8; Phil. 1:22-24; Heb. 12:9. The two elements are the body and the breath or spirit of life breathed into it by God, and by the combination of the two man became a "living soul."

The attitude of God in the process of creation could be indicative of what would be appropriate in grief ministry when it comes to the new creation of self. When confronted with the reality of suffering and death at the event of the Fall, God did not abandon His creation to its pitiful condition and did not give up on His intent to restore

${ }^{1}$ Millard J. Erickson, Christian Theology (Grand Rapids: Baker Book House, 1985), $36 \overline{6}$.

"Marcus Dods, "The Creation," The Expositor's Bible, ed. W. Robertson Nicoll (New York: A. C. Armstrong and Son, 1908), $1: 6$.

${ }^{3}$ Berkhof, 183 . 
creation (Gen 3:14-19). God did not forsake the earth, after sin, but delivered the wayward children of Israel by calling Moses to lead them out of Egypt (Exod 6:2-5). This is an illustration of how God executed a restorative plan (Rev 21:1) for the human race. Likewise, pastors who follow the divine example should not be discouraged in facilitating the grieving process.

\section{Creation and Incarnation}

While God's creation of a perfect world certainly casts light on some dimensions of grief ministry (Col 1:1016), incarnation, God's act of becoming human in an imperfect world, contributes to an even more precise understanding of grief ministry. Through this incarnation Christ demonstrated that He understood and empathized with persons experiencing "suffering, accidents, disease, loneliness, insecurity, weakness, and error." ${ }^{3}$ As a result, through a personal relationship with Christ, sinners are able to live diligently and fruitfully, and to experience growth both in knowledge and strength (Col 3:1012; Heb 4:14-16) and to be rescued from "the dominion of darkness" and unforgiven sins (Col 1:13-14).

\footnotetext{
${ }^{3}$ Paul Tillich, "The Theology of Pastoral Care," Pastoral Psychology 10, no. 97 (October 1959): 23.
} 
God actually demonstrates His character through Christ. God through the incarnation "in Jesus Christ the Supreme manifested Himself personally, and light is shed upon all that has been and is." ${ }^{1}$ Incarnation is then God's communication through Christ the Son (Heb 1:1-4) and establishes relationships and mutual responses between God and the people of this world. ${ }^{2}$ There is harmony between creation and incarnation in that the two events depict the creative power, wisdom, and affection of God. "The creation story in Genesis is retold in the Gospel of John with Christ as the Creator." ${ }^{3}$ Jesus, the Creator, condescended through incarnation to dwell and be personally identified with humankind in order to console, sustain, and redeem them (Rom $5: 12)$.

God of Creation and Worship

worshiping the Creator is mandated in the proclamation of Rev 14:6, which states, "Worship Him who made the heavens, the earth, the sea and the springs of water." A similar statement occurs in the fourth commandment along with the primary statement, "Remember the Sabbath day to keep it holy" (Exod 20:8-11). Recalling God's creative act

\footnotetext{
${ }^{1}$ Dods, $1: 14$.

${ }^{2}$ Rice, 68 .

${ }^{3}$ Oscar Cullmann, Salvation History (London: SCM Press,
} $1967), 145$. 
should motivate worshippers to celebrate. However, there is a need for the church to include an affective component in worship on the Sabbath Day: to emphasize the experience of human suffering in worship as entering into the fellowship of Christ's suffering (Phil 3:10). Therefore, worship should also help the believer to experience emotional healing as the result of a personal encounter with God.

The power stemming from the reflection of the image of God as the Creator also provides pastors a framework in their ministry to grieving persons. Thus, this power offers comfort to parishioners who attend worship in times of loss. In order to help persons experiencing loss, pastors also need to cope with their own loneliness and sense of abandonment ${ }^{1}$ by finding companionship with their Creator in worship.

The image of God as Creator demonstrates His majestic power, His condescension, His understanding of personal hurts, and His ability to provide a shield in attack. A holistic view of the world and the wholesome activities of the human race emerge when creation is seriously considered. "Man, God's creature, is the being who finds every part of

\footnotetext{
${ }^{1}$ Margaretta K. Bowers, Conflicts of the Clergy (New York: Thomas Nelson \& Sons, 1963), 3.
} 
his experience linked with other parts. This point is something made with the formula that man is a 'whole. "'

God's creativity as a Creator has also been likened to a potter as Isaiah depicts: Yet, o Lord, you are our Father. We are the clay, you are the potter; we are all the work of your hand (Isa 64:8).

\section{Implications}

Materialism and technology are present in modernized Singapore. There is a need in Singapore to understand the basic doctrine of creation. The teaching about God who created humankind is relevant in the multicultural society of Singapore since all believe that there is an origin. Myths about creation are prevalent among the various cultures. Myths about human origins tend to dilute the essence of the biblical message about Creation.

\section{God as Sustainer through Dying and Death}

\section{God's Love Contrasted with Death}

The image of God as a Sustainer of life is demonstrated when He, lovingly, warned Adam and Eve of the consequences of disobedience (Gen 2:16-17). To no avail, God warned the first parents that death would be the result of sin. Through their disobedience, sin entered the world

\footnotetext{
${ }^{1}$ Daniel Day Williams, The Minister and the Care of the Soul (New York: Harper \& Brothers Publishers, 1961), 26.
} 
and death by $\sin ($ Gen $2: 16-17 ; 3: 1-7 ;$ Rom $5: 12,19$ ). In this warning, God is shown as One who does not impose death arbitrarily. The consequences of $\sin$ are listed below:

(1) The utter corruption of humankind (Gen:5; Ps 14:2; Rom 7:18); (2) The loss of communion with God (Eph $2: 1$, $5,12 ; 4: 8)$; (3) The consciousness of guilt in the human mind (Rom 3:19); (4) The wages of sin is death (Rom $6: 23)$; (5) The human race has been barred from the tree of life until restoration at the new kingdom. ${ }^{1}$

God is responsible and orderly (1 Cor 14:40). God as Sustainer continues to seek and save the lost (Luke 19:10). Those weary of sin and death, who respond to His invitation, will find rest (Matt $11: 28$ ).

\section{God as a Shepherd}

The psalmist pictures God as a Shepherd, and human beings as His sheep (Ps 23 ). He presents "the realities of the devout life under the image of the Divine Shepherd and His lamb." 2 The image of the shepherd speaks of God's care, guidance, nurture, communion, and hope. ${ }^{3}$ The psalmist says, "Though I walk through the valley of the shadow of death, I fear no evil for you are with me, your rod and your staff they comfort me" (Ps 23:4). Christ's life and death have presented the images and activities of a

${ }^{1}$ Ibid.

"Alexander Maclaren, "Psalm 23," The Expositor's Bible, ed. W. Robertson Nicoll (New York: A. C. Armstrong and Son, $1908), 8: 227$.

\footnotetext{
${ }^{3}$ Ibid. , 227-232 .
} 
shepherd. His teachings, too, have described $\mathrm{His}$ willingness to die and His victory over death: I am the good shepherd; I know my sheep and my sheep know me--just as the Father knows me and I know the Father--and I lay down my life for the sheep" (John 10:14-15).

His prediction of death was fulfilled. The death and crucifixion of Christ on the cross fulfilled God's promises in Gen 3:15 and John 3:16. These would be the scenes one could imagine:

Since He trod the wine-press alone, His loneliness must have been oppressive, and $\mathrm{His}$ sense of responsibility, crushing. His suffering was consecrated suffering, increasing in severity as He approached the end. The suffering that began in the incarnation finally reached its climax in the passio magna at the end of His life. Then the wrath of God against sin bore down upon Him.

It is through Christ, who demonstrated God's compassion through His ministry and bore our sins on the cross, that God's love and sustaining grace help us through times of loss.

God's Sustaining Grace

According to Paul, death entered the world as a consequence of sin, and is an enemy ( 1 Cor 15:26). ${ }^{2}$ However, through God's forgiveness and Christ's power of salvation, sin is powerless. There is hope and victory in Christ ( 1 Cor 15:19, 55-56). Christ has conquered death. It is Christ who really governs the course of history (Matt

\footnotetext{
${ }^{1}$ Berkhof, 337 .

"Last Enemy," SDA Bible Commentary, ed. F. D. Nichol
} (Washington, DC: Review and Herald, 1953-57), 6:806. 
$28: 18 ; 1$ Cor $15: 22-28$ ). The grace issuing from Christ's death gives meaning to Christian faith, even in grief. God as a Sustainer in life presents the availability of care, protection, and guidance through grief. God is pictured as a loving Shepherd in Ps 23. Many other Psalms, such as Ps 103:1-5, which "give voice to mingled pain and trust,"1 blend sorrow with gladness. God is there ready to deliver sufferers "from the sicknesses and death of the spirit." Similarly there will be deliverance at the second coming of Christ.

Implications

SDAs advocate the sustaining grace and power of Christ. ${ }^{3}$ Such belief has its implications in (1) coping with grief; and (2) hope in the Second Advent.

Coping with grief

In coping with grief, one helpful attitude is to have confidence that God is able to sustain life. In this way, dying and death can be faced without fear because God is in control. Fear can result in unhealthy attachment. At the cross, Christ demonstrated a healthy relinquishment of attachment by advising Mary to take John as her son and John to accept Mary as mother (John 19:26-27).

\footnotetext{
${ }^{1}$ Alexander Maclaren, "Psalm 103," The Expositor's Bible, ed. W. Robertson Nicoll (New York: A. C. Armstrong and Son, 1908), 9:102.

${ }^{2}$ Ibid. , 103.

${ }^{3}$ Damsteegt, 352 .
} 
It is helpful for the bereaved one to say "Good-bye." Believing in the unconscious state of loved ones who die can better facilitate a "good-bye." Such acknowledgment takes the relinquishing of connection with the dead more easily. Mourners are advised to reconstruct their life through journaling and counseling. In this way, life goes on for the bereaved. Yeagley succinctly states, "Celebration of relationship precedes termination of relationship." ${ }^{1}$ This means that a ritual of celebration enables the bereaved to let go of their psychological attachment in a healthy way. It is essential that the mourners take time to reflect on the loss of the deceased. Perhaps, this was the reason for Christ to delay His visit to Lazarus's tomb (John 11:17-22). Failure to take time to cope with loss may even led to denial of reality, or even idolatry: "To be fixed and stuck in this is to worship the dead. This has been the greater idolatry throughout time. But our God is the God of the living." 2 Perpetual idolatry of the dead denies the power of the cross that is helpful in the coping process.

Hope in the Second Advent

People who believe in the Second Coming of Christ have hope in the sustaining power of God. This sense of hope of God's sustenance through life and death assures an eternal

\footnotetext{
${ }^{1}$ Yeagley, 35

${ }^{2}$ Wayne E. Oates, Your Particular Grief (Philadelphia: Westminster Press, 1981), 109.
} 
reunion with the deceased and gives help in the grief recovery process.

\section{God as Redeemer in Resurrection}

\section{God Provides Renewal}

After describing the Redeemer's role in human history, the Psalmist accents the role of God as the Renewer of Iife on "the face of the earth" (Ps 104:30). God is described as a Lover of life and is the Redeemer. The Psalmist's words were manifested through Christ's promise, "Because I live, you also will live" (John 14:19). For example, in 1 Kgs 17:7-24, Elijah's resurrecting a widow's son demonstrates God's restorative power. This is only one of the many events in the old Testament. There are also numerous lifesaving events in the New Testament such as the raising up of the widow's son at Nain (Luke 7:11-15). Further, Paul acknowledges that his desire to live comes from knowing Christ, and experiencing the power of Christ's resurrection (Phil 3:10). In this manner, his belief attains the resurrection (Phil 3:11).

\section{Christ Is the Resurrection}

Being empowered by God, Christ helped the suffering people through His teaching and healing. Christ set such ministry as an example for His disciples. Through miracles in the New Testament, Christ has demonstrated the principles of the kingdom founded on love. 
The power demonstrated in the resurrection of Lazarus by Christ brings hope to the human race. Lazarus was sick and died, but Christ brought him back to life again. Christ's power of resurrection gives comfort to the believers (John 11:1-45).

In the context of Lazarus's tomb, Christ wept. He wept both as an expression of empathy for the grievers and as an anticipation of His own imminent death. ${ }^{1}$ Christ's grief was also caused by His burden of human sin:

It was not only because of the scene before Him that Christ wept. The weight of the grief of ages was upon Him. He saw the terrible effects of the transgression of God's law. He saw that in the history of the world, beginning with the death of Abel, the conflict between good and evil had been unceasing. ${ }^{2}$

Christ commanded that the stone that sealed Lazarus's tomb be removed. He called Lazarus to life. Thus He performed a creation very similar to the manner in which He breathed Adam into being. Through Christ, there is hope beyond loss, even the loss of life. Christ can restore life and renew Christian faith just as He did for Lazarus and his family. The resurrection of Lazarus is a demonstration of a greater miracle:

The 'truth' of the Lazarus story is far greater than a literalistic, unimaginative reading of it could reveal: it contains not the resuscitation of one dead man, out of all the millions of human dead, but the appearance in the history of this world of him who is the creator of life itself, Jesus the Son of God, the resurrection of life. ${ }^{3}$

${ }^{1}$ Ellen G. White, Desire of Ages (Washington, DC: Review and Herald Publishing Association, 1964), 516.

${ }^{2}$ Ibid., 517 .

${ }^{3}$ Alan Richardson, The Gospel According to Saint John (London: SCM Press, 1980), 138-139. 
This miracle is the evidence of Christ's powerful claim, "I am the resurrection and the life. He that believes in Me will live, even though he dies" (John 11:25). There are lessons to learn in the resurrection of Lazarus:

1. There is resurrection power in Christ's words. The resurrection of Lazarus was an evidence that there is hope for the grieving. The resurrection of Lazarus was a type of Christ's own resurrection.

2. The death and resurrection of the Savior is the event in which all deaths and resurrection find reality. It is the demonstration of His power of resurrection.

By His word and His works He declared Himself the Author of the resurrection. He who Himself was soon to die upon the cross stood with the keys of death, a conqueror of the grave, and asserted His right and power to give eternal life. ${ }^{3}$

The hope of resurrection provides the bereaved ones with comfort and assurance that there will be no more death ( Rev $21: 1-4)$.

God and New Creation (Rev 21:1-4)

Rev 20 and 21 have revealed God as the Almighty One who will restore Paradise. Christ's resurrection is the assurance not only of the saints' resurrection $(20: 4,6)$, but also the "resurrection" of the soon-to-be devastated earth (21:1). "All trials will be over, and there will be no more sickness or death."

${ }^{1}$ White, Desire of Ages, 477 .

2 "Revelation," SDA Bible Commentary, ed. F. D. Nichol (Washington, DC: Review and Herald, 1953-1957), 7:988. 
Christ understands the various aspects of suffering. Christ's presence and power have brought healing to humankind. In Jesus' time, the people were in spiritual đarkness.

"For more than a thousand years the Jewish people had waited the Savior's coming." Christ was their brightest hope. In grief, the life-giving power of Christ both in resurrection and renewal provides perspective in life. This life-giving power transcends the love human beings can provide and inspires faith ( 1 Cor $15: 14,17$ ). Resurrection assures us abundant life even now (John 10:10) and provides assurance to an eternal union with God (Rev 21:1-4) and with the loved ones throughout eternity ( 1 Thess $4: 16-18$ ).

\section{Implications}

God is sovereign and has the absolute authority to control even life and death. The image here tells about a compassionate and sinless Savior who understands all our grief and was tempted in all ways as human beings are (Heb $4: 14-16)$.

\section{God as Comforter in Grief}

\section{God who Comforts}

The images of God as Creator, Sustainer, and Redeemer will blend with the image of a Comforter. Let this

\footnotetext{
${ }^{1}$ White, Desire of Ages, 9.
} 
statement, which vividly describes the power of the Holy Spirit, be considered:

In this time, when the foundations of faith are being shaken, when the hopes of men are perishing, when souls are filled with darkness and foreboding and doubt, and multitudes are crying for the sound of comfort and hope, God calls for His faithful bell ringers to peel out to the church and world, "Holy Spirit, light divine."

God as a Comforter also proclaimed comfort when Christ pronounced blessings in the sermon on the Mount (Matt 5:312. "Blessed" (Gr. makarious) means "happy." The word, "blessed," "occurs primarily with the sense of 'happy, fortunate,' illustrating the joy of life unmarred by care, labor, or death." Although Christ referred to this as the conduct that meets with God's approval and has characteristics of eschatological blessedness, He meant that such joy of life was also a result of mourning for sin experienced by His covenant people on earth. ${ }^{3}$ For example, blessings were experienced individually by David's repentance and Paul's conversion from their sin (Ps 51:10; Acts $9: 17-19)$.

${ }^{1}$ LeRoy Edwin Froom, The Coming of the Comforter (South Bend, IN: Review and Herald Publishing Association, 1928), 204 .

${ }^{2}$ A. C. Myers, "Bless," The International Standard Bible Encyclopedia (1979-1988), 1:523-524.

${ }^{3}$ Ibid. 
God also provided encouragement to the disciples in the Upper Room, and during Pentecost, when He sent the Holy Spirit as "another Comforter" (John 14:16; Acts 2:1-4).

The "basic meaning of Comforter (Gr. Parakletos) is 'one called to the side of.' Together with this passive sense 'thus signifying one who stands by to aid and succor', it denotes one who as a 'counselor' (KJV 'comforter'; John 14:16, 26; 15:26; 16:7) exhorts, strengthens, and comforts another." 1

\section{Christ Comforted His Disciples}

In John 14:16, Christ promised His disciples "another Comforter." The word "another" (Gr. allon) "means another of the same kind, not of different kind." ${ }^{2}$ It implies that Christ "is a Comforter" as in John 14:16.

As the Comforter, Christ comforted His disciples during His earthly ministry until His ascension. He also comforted the apostle John at Patmos (Rev 22:14). After Pentecost, God as the Holy Comforter is described as one who gives much consolation in moments of anxiety, despair, and anticipation (1 Pet 5:7; 1. John 4:18). Those who experience "godly sorrow" are brought to "repentance that leads to salvation" (2 Cor 7:10).

${ }^{1}$ G. W. H. Lampe, "Paraclete," The Interpreters Dictionary of the Bible (1962), 3:654-655.

${ }^{2}$ C. Tenny, "The Gospel of John," The Expositor's Bible Commentary (1981), 9:146. 
The caring scene of joy at Pentecost invokes retrospection to Creation when the image of God is that of One who came so near as to breathe into Adam's nostrils (Gen $2: 7)$

The Creator reveals His care for the creation, for the race of men, for every kind of being and every need. He declares His own glory, of transcending power, of immeasurable wisdom, also of righteousness and holy will. He can afflict men, and yet do them no wrong but good, for they are His men, for whom He provides as they cannot provide for themselves. Trial, sorrow, change, death--is anything "disastrous" that God ordains? Impossible. ${ }^{1}$

History is heightened in "one event: the crucifixion of Christ and the subsequent resurrection." ${ }^{2}$ Paul affirmed the power of the resurrection. Without it, there is no hope; and faith is in vain (1 Cor 15:17-19).

Complementing His role as a Comforter, God has been described as "Counselor" (John 14:16). This latter function implies more than providing spiritual and empathetic effects. It has "admonitory, encouraging, and consolatory exhortation for the purpose of strengthening." ${ }^{3}$ God's influence as Counselor to the grieving can be further amplified psychologically to add to the variety of the spiritual roles of God.

${ }^{1}$ Walter F. Adeney, "Music in the Bounds of Law," The Expositor's Bible, ed. W. Robertson Nicoll (New York: A. C. Armstrong and Son, 1908), 7:381-382.

${ }^{2}$ Cullmann, Salvation History, 86.

${ }^{3}$ Cremer Hermann, Biblico-theological Lexicon of New Testament Greek (Edinburgh: T. \& T. Clark, 1880), s. v. "paraclete." 
Implications

God, as a Comforter, is an active Person in the world of chaos. Christ's promise of a Comforter to the disciples gives us assurance that God cares about our losses. Counselors in order to be fruitful tend to agree and disagree with their clients appropriately. God who comforts the grieving also strengthens the grieving by His counseling role.

\section{Conclusion}

In many places, as in Singapore, numerous people have become involved in materialism and rationalism, which have "launched an attack on the Church's doctrine of creation."1 Being alienated from God, the Source of hope, humanity may sense the need for re-creation, sustenance, redemption, and comfort, which God alone can provide.

Attacks on creation were encountered in the modernization of Singapore when the murals in its science center and films in recreational grounds depict life's origin as being based on evolution. But genuine biblical images of God as Creator, Sustainer, Redeemer, and Comforter help pastors to articulate more clearly their concepts of God. This enhances their knowledge about God and their own pastoral identity. At times, the courage to be different, in order to exercise power, transcend the cultural norms.

\footnotetext{
${ }^{1}$ Berkhof, 127 .
} 
Pastors who continue to formulate their pastoral identity by reflecting on God as Creator, Sustainer, Redeemer, and Comforter set appropriate examples for their members. When pastors thus become certain of their own identity, their members will also become more secure about their own identity. The pastors' clarity about the image of God helps mourners to relate to grief appropriately in times of loss. Pastors who experience care, protection, and guidance in grief are able to minister fully to those who suffer loss. Pastors who continue to meditate on the images of God are able to reaffirm their pastoral identity. 
CHAPTER III

PRACTICAL RESOURCES FOR COPING WITH GRIEF

\section{Introduction}

This chapter focuses on practical resources for pastors towards the development of a pastoral perspective for grief ministry. These resources are based on the Bible, the roles of SDA pastors, CPE, culture, and personal development.' The practical resources in this chapter are outlined as follows:

1. SDA pastors' roles as articulated within a Biblically based understanding of God's images in creation, death, and resurrection;

2. CPE alongside theological education;

3. Cultural values in the Yin/Yang concept; and

4. Personal development of the self-image as part of a pastoral perspective.

The suggestion is to develop a holistic pastoral perspective. This challenges pastors to examine their

${ }^{1}$ In his book on practical ministry, Oates has advocated the components of the pastoral identity as follows: the pastor's faith relationship with God, to the community and to self. He also recognizes that the dynamics of preaching, teaching, and healing come from the same sources: personality and pastoral identity. Wayne E. Oates, $\underline{A}$ Practical Handbook for Ministry (Louisville, KY: Westminster Press, 1992), 16, 29. 
theological orientations, their roles as pastors, their responses to pastoral education, and their self-development.

\section{Pastors' Roles in Relation to God's Images}

The images of God in a pastor's mind often determine the pastor's role. Oates pointed out that a clear understanding of pastoral roles helps to determine a pastor's effectiveness." He also stated that a pastor's effectiveness can be jeopardized by "internal contradictions." ${ }^{2}$ For example, Jesus' disciples were fearful when they were confused about His mission on earth. After Christ appeared to them after $\mathrm{His}$ resurrection, they acknowledged Him as Lord and God (John 20:24-28). When the image of Christ was made clear through $\mathrm{His}$ appearance, they became confident of their identity.

The way to prevent these contradictions is to focus on the images of God. When the images of God are clearly focused in the pastor's mind, the pastor relates himself/herself to God in such a way as to form a healthy self-image. ${ }^{3}$ Biblical examples illustrating this clarity of self-image are: Jacob after wrestling with the angel and Thomas encountering the resurrected Christ (Gen 32:22-30; John 20:24-28). Paul, for example, had distorted images of

\footnotetext{
${ }^{1}$ Oates, A Practical Handbook for Ministry, 17.

${ }^{2}$ Ibid.

${ }^{3}$ Darryl J. Tiller, "The Self as Instrument," in The Supervision of Pastoral Care (Louisville, KY: Westminster/John Knox Press, 1989), 146.
} 
God. The priests and rulers had convinced him that Christ was an imposter. This led him to be a bitter opponent of the teaching of Christ. This opposition took the form of fierce persecution. He, however, was made to develop a new self-image on the road to Damascus when he encountered Christ face to face. 'This personal communion resulted in the discarding of the prejudices and tradition that had previously shaped his life, and established him in the faith. In this way he came to see his true pastoral role. Paul emphasized the pastoral role when he presented Christ as the "image of the invisible God" and Creator of all things $(\operatorname{Col} 1: 24,29) .^{2}$ In the same message (vss. 2829), Paul commissioned ministers to their roles after he reflected on the images of God. The pastor's self-images were listed as (1) preacher, (2) teacher, and (3) suffering healer ( $\operatorname{Col} 1: 23-29)$. This coincides with the SDA mission of preaching, teaching, and healing (see Appendix A).

The following sections deal with the roles of an SDA minister as a preacher, teacher, and suffering healer in relationship with several selected fundamental doctrines of the SDA Church.

${ }^{1}$ Ellen G. White, The Acts of the Apostles (Mountain View, CA: Pacific Press Publishing Association, 1963), 113126.

${ }^{2}$ Paul implies that by beholding the glorious image of the Creator/Redeemer ( 2 Cor $3: 18$ ), pastors gain a holistic perspective that contributes to their understanding of their pastoral role. 
Pastoral Role as Preacher

SDA congregations in Singapore show respect to

preachers who preach practical sermons, feed the flock, and demonstrate competence in pastoral ministry. Preachers are important because a substantial amount of time in interaction with parishioners takes the form of preaching. The following are some of the functions the pastor-preacher performs that meet the needs of the grieving: (1) in Sabbath celebration, (2) in sharing the gospel message, and (3) in preaching the resurrection of Christ.

In Sabbath celebration

During Sabbath worship, a preacher has the solemn responsibility of leading congregations to celebrate the creative power of God and to acknowledge such power through worship and service (Rev 14:6-7). At this holy hour, the preacher is to lead the congregation to a deeper communion with God, humbly acknowledging the presence of the Creator. Regarding the Sabbath, SDAs emphasize:

The Sabbath, on the other hand, encourages not a permanent escape from this troubled world, but only a one-day weekly interlude in or to catch a glimpse of the divine realm of order, purity and love. ${ }^{1}$

The Sabbath celebration also implies putting God first and conforming to His expressed will. Thus the Sabbath touches all dimensions of life. ${ }^{2}$

${ }^{1}$ Bacchiocchi, 74 .

${ }^{2} \mathrm{Jack}$ Provonsha, A Remnant in Crisis (Hagerstown, MD: Review and Herald Publishing Association, 1993), 87. 
When parishioners are grieving, the role of pastors is to help them appreciate God's special Sabbath worship presence and sense the comfort of Christian fellowship. When this world's transitory reality is seen in the context of God's caring will, there is an expectation of comfort from God. The perimeter of Sabbath celebration also provides special opportunities for loved ones and friends to come close to one another and provide corporate comfort to those who mourn.

In sharing the gospel message

During Sabbath worship, the preacher proclaims hope in Christ. Christ commissioned His people to preach the gospel to the whole world. The central theme of the SDA message is found in Rev 14. It begins with the mandate: "Fear God and give him glory, because the hour of his judgment has come. Worship him who made the heaven and the earth, the sea and the spring of waters" (Rev 14:7). The call to worship God is also to participate in the suffering of Christ by the believers:

Christian worship celebrates the God who has chosen to enter into our human frame of reference, to participate in our troubled condition, and to affirm human existence by sharing in it in all its radical contingency, suffering, and death.

The suffering aspect of worship is vivid when Rev 14 is studied as a whole, particularly with reference to Rev

\footnotetext{
${ }^{3}$ Thomas C. Oden, "Recovering Lost Identity," The Journal of Pastoral Care 34, no. 1 (1980): 4 .
} 
14:4 and Rev 14:12, which precedes and follows the Three Angels' message of Rev 14. Rev 14:4 speaks of "following the Lamb" and Rev 14:12 speaks of "patient endurance on the part of the saints." Commenting on God's people following the Lamb, White depicted a scenario of a trial, "We are to follow Him by suffering for His sake, say, at every'step, 'Though he slay me, yet trust in him."' Another commentator stated that those who follow Him participate in His humiliation, labors, suffering, death, resurrection, and ascension. These followers follow Him in persecution or in triumph. ${ }^{2}$ The suffering aspect of worship presents a wholesome picture of Christians who believe the message of Rev 14. When sufferings are anticipated as part of worship in both corporate and private environments, worshippers are prepared to encounter joy or trial for their faith. ${ }^{3}$ In Rev 14:12, there are two characteristics of God's people. One is the cultivation of "patience" and the other is obedience to God's commandments. "Patience" is translated as "steadfast endurance" in developing character.

"God's People Follow the Lamb Now," SDA Bible Commentary, ed. F. D. Nicoll (Washington DC: Review and Herald, 1953-1957) 7:978.

${ }^{2}$ William Alexander, "Lamb on the Mount Zion," The Expositor's Bible, ed. W. Robertson Nicoll (New York: A. C. Armstrong and Son, 1908), 25:243.

${ }^{3}$ Ellen G. White, Great Controversy (Washington, DC: Review and Herald Publishing Association, 1958), 619.

4"Patience," SDA Bible Commentary, ed. F. D. Nichol (Washington, DC: Review and Herald, 1953-1957), 7:832. 
Christian worship develops the character of the believers for heaven, and suffering is part of the discipline with the expectation of being rewarded by the heavenly hope. ${ }^{1}$

Therefore, worship celebrates the presence of God with us in our gains and losses. It invokes appreciations in our increases and also commemorates our losses. Pastors play a crucial role in communicating this to grieving members.

In preaching the resurrection of Christ

In the preaching of the gospel, pastors are to proclaim the hope of the resurrection. The resurrection of Jesus is the assurance that we can live a new life if we die to sin and are baptized into Christ (Rom 6:2-4): "We were therefore buried with him through baptism into death in order that, just as Christ was raised from the dead through the glory of the Father, we too may live a new life" (vs. 4). This new life is a foretaste of the "everlasting life" (John $3: 16$ ) bestowed when Christ comes ( 1 Cor 15:51-53; 1 Thess $4: 16$ ). This is an encouragement to the bereaved (vs. 18). White's admonition to the pastor is:

Present the Truth as it is in Jesus. Make plain the requirements of the law and the gospel. Tell the people of Christ's life of self-denial and sacrifice; of His humiliation and death; of His resurrection and ascension; of His intercession for them in the courts of God; of His promise, "I will come again, and receive you unto Myself" John 14:3.2

${ }^{1}$ Willam Alexander, "Harvest of the Vintage of the World," Expositor's Bible, ed. W. Robertson Nicoll (New York: A. C. Armstrong and Son, 1908), 25:252.

${ }^{2}$ Ellen G. White, Christ's Object Lessons (Washington, DC: Review and Herald Publishing Association, 1941), 40. 
Those grieving can find strength through the preaching of the resurrection.

\section{Pastoral Role as Teacher}

The objective of SDA education is to "restore men to the image of the Creator." ${ }^{1}$ One way in which this is done is through Sabbath worship. Another way is the manner in which pastors set examples and lead out in private worship. To worship personally and corporately on Sabbath can prepare one to go through the initial stages of grief: shock, unbelief, bargaining, anger, and denial. God's presence brings healing in these stages. In this way, meaningful worship enables men and women to have an education that brings them to the restoration of the "image of God."2 Teaching through meaningful worship, then, is an important responsibility of the pastor as a teacher. Teaching through the pastor's life and actions beyond the pulpit duties, then, is an important responsibility of the pastor as a teacher. Teaching by example is part of the early church tradition practiced by Christ and His disciples. ${ }^{3}$ The teaching of Creation is fundamental in pastoral ministry in which grief recovery is part of. One occasion when Jesus

\footnotetext{
${ }^{3}$ White, Education, 16 .

${ }^{2}$ Ibid. , 15 .
}

${ }^{3} \mathrm{Clark}$ M. Williamson and Ronald J. Allen, The Teaching Minister (Louisville, KY: Westminster/John Knox Press, 1991), 44 . 
taught by example was by washing the disciples' feet (John $13: 3-5)$.

of Creator-creation relationships

Christ focused on relationships between God and humankind, particularly in the last days of His earthly ministry (John 15). White also taught that pastors ought to have their profession founded on Christ in order to attain a close relationship with God the Creator. ${ }^{1}$ Christ had set an example: to relate with God and humanity one needs to employ preaching and teaching both from the Bible and from nature. ${ }^{2}$ Since a pastor's influence extends beyond the pulpit, his/her life and pastoral visits convey messages of the Creator and His creation. The SDA Church teaches that "the doctrine of creation gives us a basic understanding of God's relation to the world." ${ }^{3}$ God created human beings with the abilities to relate to Him and to their fellow human beings by loving and serving them. Provonsha further has substantiated:

Nothing said about God in the Bible is clearer than that $\mathrm{He}$ is Creator of everything that is, and not only Creator but Sustainer, sustaining all things by his powerful word (Heb. $1: 3) .^{4}$

${ }^{1}$ Ellen G. White, Medical Ministry (Mountain View, CA: Pacific Press, 1952), 255.

${ }^{2}$ Ellen G. White, Gospel Workers (Washington, DC: Review and Herald Publishing Association, 1958), 408.

${ }^{3}$ Rice, 72 .

${ }^{4}$ Provonsha, 69 . 
The Creator-creature relationship that Christ lived and taught gives purpose to our existence and meaning to our suffering and pain. Such a relationship may enable grieving persons to find strength, hope, and power in times of "weakness, helplessness and powerlessness." ${ }^{1}$ With reference to this relationship, Dwight Nelson in a sermon said, "He who created you will liberate you."2 God's creative power facilitates a growing process in grieving.

of truth about death

SDA pastors are called to preach the truth about the biblical doctrine of death. The common misunderstanding of the doctrine of death can be traced to the garden of Eden when the enemy of God distorted the truth about death (Gen $3: 1-4)$. The view of popular Christian teachings regarding death is contrary to the Bible. Non-SDA Christians in Singapore, as a whole, do not believe in the biblical unconscious state of the dead according to the Bible.

Roman Catholics ${ }^{3}$ and most Protestants ${ }^{4}$ teach the immortality of the soul. SDAs derive their teaching of the

${ }^{1}$ Oates, Your Particular Grief, 110.

${ }^{2}$ Dwight Nelson, "Color Me Green," sermon presented April 3, 1993, Pioneer Memorial Church, Berrien Springs, MI.

${ }^{3}$ The Catholic Encyclopedia (New York: Robert Appleton Company, 1910), s.v. "dead." Catholics "ordinarily understood the doctrine that the human soul will survive death, continuing in the possession of an endless conscious existence."

${ }^{4}$ Martin Ebon, "Bishop Pike's Seance," in Communicating with the Dead (New York: New American Library, 1968), 3-9. Bishop Pike's statement cited is typical of the belief of most Protestants. 
state of the dead from the Bible. Cullmann concurs with SDAs by identifying the general Christian misconception of the state of the dead as originating from the Greek philosophy. He considers this misconception as "one of the greatest misunderstandings of the Christian Eaith." ${ }^{1}$ The doctrine of Christ has been collaborated in biblical events. Christ's testimony after His resurrection is that He had not yet ascended to the Father (John 20:17). This is consistent with other Scripture that teaches the unconsciousness of the dead (Eccl 19:5-6; Job 7:9-10).

Adam died after he committed sin (Gen 5:5). His death makes false the serpent's (Satan's) claim that human beings "shall not surely die" $(3: 4)$. When human beings die, they are in the state of unconsciousness. "The dead know nothing" (Eccl 9:5). Other biblical texts state: "his thoughts perish" (Ps 146:4); "he shall return no more to his house" (Job 7:9:10); and being created from dust, at death his body ("bâsâr" in Heb. from Job 19:26 and Prov 5:11)2 returns to dust (Gen 3:19), while his breath ("rûwach" in Heb. from Eccl $3: 19)^{3}$ returns to God (Eccl 12:7; 3:19-21). The teachings about the resurrection ( 1 Thess 4:16-17) and the Second Coming (Dan 12:2) are encouraging. Paul exhorts, "Wherefore comfort one another with these words" ( I Thess $4: 18$ ). One can face life's lasses fearlessly, when the true

${ }^{1}$ Cullmann, Immortality of the Soul or Resurrection of the Dead? 10.

${ }^{2}$ William L. Holladay, A Concise Hebrew and Aramaic Lexicon of the Old Testament (Grand Rapids: Wm. B. Eerdmans, 1971), s.v., "bâsâr."

${ }^{3}$ Ibid. , "rûwach." 
"Wherefore comfort one another with these words" ( 1 Thess 4:18). One can face life's losses fearlessly, when the true meaning concerning the present and the future is known. There is a God who cares; death is not the end. SDA pastors have the responsibility to teach the mortality of the soul.

Of the resurrection hope

SDAs believe in two resurrections: the resurrection unto life and the resurrection unto damnation (John 5:2829). The resurrection of the righteous will occur at the Second Coming of Christ.

For the Lord Himself will come down from heaven with a loud command, with the voice of the archangel and with the trumpet call of God, and the dead in Christ will rise first ( 1 Thess $4: 16$ ).

The resurrection of the righteous occurs at the end of the thousand years. As the Bible says, "The rest of the dead did not come to life until the thousand years were ended. This is the first resurrection" (Rev 20:5). These two resurrections will be separated by a millennium:

The millennium is the thousand-year reign of Christ with His saints in heaven between the first and second resurrections. During this time the wicked dead will be judged; the earth will be utterly desolate, without living human inhabitants, but occupied by satan and his angels. At its close Christ with His saints and the Holy City will descend from heaven to earth. ${ }^{1}$

The unrighteous will be destroyed forever (Rev 21:8).

${ }^{1}$ Damsteegt, 362. The author explained the millennium in details under the subtitle, "The Second Advent." He said, "Revelation 19 and 20 belong together; there is no break between these chapters. They describe Christ's coming (Rev. 19:11-21) and immediately continue with the millennium, their sequence indicating that the millennium begins when Christ returns" (363). 
Pastoral Role as Healer

SDAs teach and practice the ministry of healing. This is partly because of their comprehension of Christ's earthly ministry (Matt $4: 23 ; 1$ Pet $2: 24$ ) and His ministry in the heavenly sanctuary (Heb $8: 1-2$ ).

Through mediation

The work of the Father, and His Son Jesus, is an attempt to restore God's image in man physically (vs. 8) and spiritually (vs. 14). The spiritual aspect of restoration is embodied in Christ's mediation in the heavenly sanctuary. Christ's daily care for His people in the heavenly sanctuary is on a moment-by-moment basis. ${ }^{1}$ Christ has gone to heaven as our "merciful and faithful high priest in service to God" (Heb 2:17). Upon believing Christ to be their Mediator in heaven, persons receive renewal, healing, and hope (Isa $53: 5,13 ;$ Heb $4: 14-16)$.

Through hope

If the message of hope is reflected in the pastor's Iife, it illustrates the mighty power of God as it energizes every faculty of a believer's life. Paul identified how, in his labor and struggles, he obtained energy and power from God (Col 1:29). While he was in prison, he sought to encourage his fellow believers in Colossae. Furthermore, in similar words of encouragement, Ellen G. White stated,

${ }^{1}$ C. Raymond Holmes, "The Gospel of the Sanctuary," Adventist Affirm, Fall 1992, 51. 
"Those who surrender their lives to His guidance and to His service will never be placed in a position for which He has not made provision." ${ }^{1}$ Christ is the Guide, Counselor, and Friend to those who surrender to His will and services. ${ }^{2}$ For example, White offers hope to those in misery and desolation when she says,

Yet the race was not left without hope. By infinite love and mercy the plan of salvation had been devised, and a life of probation was granted to restore in man the image of his Maker, to bring him back to the perfection in which he was created, to promote the development of body, mind, and soul, that the divine realized--this was to be the work of redemption. ${ }^{3}$

White's source of strength in coping with grief was found in the hope of reunion with her loved ones through the resurrection of Christ. Her renewed hope was expressed at the funeral service of her husband. She said with assurance, "I look to that morning when the broken family links shall be reunited and we shall see the King in His beauty." She believed that "the plan of redemption has invested humanity with great possibilities." ${ }^{5}$ Similarly, the pastor can give a testimony of hope. Like Ellen G.

${ }^{1}$ Ellen G. White, Ministry of Healing (Washington, DC: Review and Herald Publishing Association, 1958), 248.

${ }^{2}$ Ibid.

${ }^{3}$ White, Education, 15-16.

${ }^{4}$ Arthur L. White, The Lonely Years: 1876-1891, vol. 3 of Ellen G. White (Washington, DC: Review and Herald, 1981$86), 3: 176$.

${ }^{5}$ E. G. White, Conflict and Courage (Mountain View, CA: Pacific Press Publishing, 1965), 309. 
loved ones can find much power to cope through God's promises.

Through health ministry

The SDA Church emphasizes a holistic health-based lifestyle complemented by a world-wide medical work. It has a well-integrated teaching of the eight facets of a balanced healthy life (known as NEWSTART, an acronym that stands for nutrition, exercise, water, sunshine, temperance, air, rest, and trust in divine power $)^{1}$ and a global system of medical institutions. Thereby, it makes every effort to fulfill the healing aspect of its mission.

A great work of reform is demanded, and it is only through the grace of Christ that the work of restoration, physical, mental, and spiritual can be accomplished.

Infusing this healing work are the ministries of presence and prayer. The presence of Christ in the ministry of clergy persons to the grieving helps to dispel loneliness and bring mental and spiritual healing. ${ }^{3}$ Earnest prayer, with faith and meditation, facilitates a person's ability to cope with grief. It is important to fill the void of loneliness with "the companionship of the Holy spirit."

\footnotetext{
${ }^{1}$ Patty Ann Schwab, "A Brief Look at Weimar Institute" (M.A. thesis, Andrews University, 1981), 15.

${ }^{2}$ White, Ministry of Healing, 143 .

${ }^{3}$ L. Rebecca Propst, Psychotherapy in a Religious Framework (Portland: Human Science Press, 1988), 14 .

"Oates, Your Particular Grief, 109.
} 
Healing of persons in suffering becomes possible when sufferers know that there is a Creator who cares and leads them through their suffering. Healing, in the divine plan of redemption, is the continuity of the creative ministry of Christ and restoration from the brokenness due to sin.

When pastors anchor themselves in the Creator, there is a flow of energy to bring healing to their members. Christ Himself demonstrated this healing process in His earthly ministry. "If a man is thirsty, let him come to me and drink. Whoever believes in me, as the scripture has said, streams of living water will flow from within him" (John $7: 37-38$ ).

\section{Practical Suggestions}

Pastors who care for the grieving ones direct mourners to God through preaching, teaching, and healing. Pastors themselves need to get in touch with their Creator before they can fully point believers to God. Through "the manifold wisdom of God" (Eph 3:10), pastors will help the grieving to cope with loss.

If pastors teach fully the doctrine of creation and redemption, members will find meaning in times of suffering and death. The SDA Church teaches that the resurrection and Second Advent of Christ at the end of the age of sin and death bring hope to the grieving. God will then create everything new for eternity. There will be no more death, or crying, or pain (Rev 21:4-5; 2 Pet 3:13). 


\section{Clinical Pastoral Education for Grief Ministry}

In looking for a viable program that is based on biblical values for the training of pastors, CPE, pastoral counseling, and psychotherapy should be explored. CPE is highlighted here because it has much greater emphasis on theology and on the integration of theory and practice in pastoral ministry. Theology and integration of theory and practice are integral to SDA education whose goal is to restore humankind to the image of God. Education involves the total being, including the physical, mental, spiritual, and social aspects of being (Luke 2:52). SDAs have fostered these aspects through their health and educational principles and institutions. For example, Loma Linda University teaches advanced studies in medical science and bioethics. Its School of Medicine has the mission: "A SDA Christian health sciences institution, seeks to further the healing and teaching ministry of Jesus Christ, 'To Make Man Whole."' This mission advocates a holistic approach. This has been applauded by Christians and non-Christians. Adventist Chaplaincy Ministries Department, one organization fostering holistic pastoral care, advocates CPE training. SDA institutions that offer CPE are Boston Regional Medical Center, Florida Hospital, Kettering Medical Center, Loma Linda University, and Shady Grove Adventist Medical Center. The following section discusses the

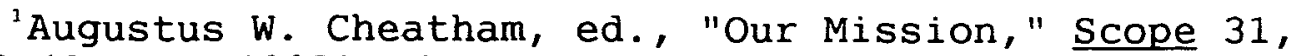
no. 2 (Summer 1995): 41 .
} 
pastoral elements of CPE such as its emphasis, methods, its integration of faith and ministry, and its similarity to Christ's method of training.

\section{Pastoral-Care Emphasis}

The SDA Theological Seminary of Andrews University has a chaplaincy program that refers Seminary students to CPE programs across the United States and Canada. The Seminary gives academic credits towards the Master of Divinity degree to those who have completed CPE units. ${ }^{1}$ Pastors and chaplains in Singapore are encouraged to enroll in clinical pastoral training at a local Clinical Pastoral Care Center $(\mathrm{CPC}) \cdot{ }^{2}$

\section{Clinical Methods}

The world today is undergoing changes. People caught in these transitions often experience grief. ${ }^{3}$ There are emphases in clinical pastoral methods that are useful in equipping pastors to cope with their own grief and with parishioners' grief. The movement in pastoral education that began to provide caring services in medical centers in

${ }^{1}$ Seventh-day Adventist Theological Seminary 1995-1996 Bulletin (Berrien Springs, MI: University Press, 1995), 78 . According to what James North said in an interview, the CPE adviser of the Seminary, "The Seminary is looking at CPE closely and critically. It does not support all CPE programs without reservation."

${ }^{2}$ The name Cinical Pastoral Care (CPC) is used in order to not confuse it with $C P E$ and is freed from accreditation requirements of the Association of CPE.

${ }^{3}$ Williams and Sturzì, 57. 
the early 1920s has made an impact in pastoral care and counseling. A brief description of CPE is presented below.

CPE was developed by Dr. Richard C. Cabot, M.D., and the Reverend Anton J. Boisen--both of the Greater Boston, Massachusetts, area--in the mid-1920s. CPE combines the learning of pastoral care in the clinical setting, principally the hospital. The integration of theological studies and applications with clinical ministry, which the Reverend Boisen called 'a study of the living human documents,' continues to influence pastors and chaplains in pastoral care. ${ }^{1}$ CPE leaders have increasingly integrated a knowledge and understanding of medicine, psychology, sociology, and other behavioral sciences into the further development of CPE methods and practice. ${ }^{2}$

CPE can complement the holistic theological emphasis of the SDA Church. Practical training of pastors can be accomplished through this integration of theology with principles of pastoral care in examining "the living human documents." ${ }^{3}$ This method of applying theology to pastoral

${ }^{1}$ Charles V. Gerkin, The Living Human Document (Nashville, TN: Abingdon Press, 1984), 37.

${ }^{2}$ David M. Hurst, "The Role and Function of Clinical Pastoral Education (CPE)," Southeast Michigan Cluster News Release, September 25, 1992, 1 .

${ }^{3}$ Ibid. Mr. Anton J. Boisen himself had experienced six major losses in his life. It was through these grief events that he did empirical studies of human nature and of religious experience and published the book, out from the Deep (New York: Harper and Brother, Publishers, 1960). 
care should be encouraged because it facilitates a broad professional growth. Its effectiveness in pastoral ministry has been demonstrated in the lives and ministry of many pastors of all denominations.

\section{Integration of Faith and Ministry}

Further, SDA educators have recommended the integration of faith and ministry in supporting pastors through grief ministry. ${ }^{3}$ In alignment with this thinking, CPE provides therapeutic supports to pastors who may be experiencing burnout, and offers methods for coping with stress. Thus, its principles can be useful in grief ministry because bereavement is stressful. It also complements the theological training and evangelistic emphasis of the SDA Church.

Comparison with the Teaching Techniques of Christ

Jesus Christ spent more time in healing than in teaching or preaching. ${ }^{2}$ His message contains essentials for coping with grief as found in the Beatitudes (Matt 5:4), the story of the transfiguration (Matt 17:1-13), the

${ }^{1}$ Benjamin D. Schoun, Helping Pastors Cope (Berrien Springs, MI: Andrews University, 1981), 131. A careful selection of CPE Centers that advocate biblical principles is necessary because each has its emphases and biases.

${ }^{2}$ White, Ministry of Healing, 19 . 
resurrection of Lazarus (John 11:1-44), and the Upper Room where He bid farewell to His disciples before His death (John 14 and 15).

Some methods in the CPE program are similar to the teaching techniques of Christ. Some are listed below:

1. The supervision of students under CPE supervisors is similar to Christ's way of training His disciples. Teaching is done in small groups and on a one-to-one basis in supervisory sessions (Matt 4:18-20).

2. The use of case studies in CPE is also exemplified by Christ as He taught the disciples through stories He told such as the prodigal son (Luke 15:11-32) and the good Samaritan (Luke 10:30-37).

3. The use of appropriate clarification, confrontation, and empathy in CPE is similar to the way Christ taught His disciples. For example, Jesus confronted the disciples for their little faith when they were not able to heal the epileptic boy (Matt 17:17-20).

\section{Practical Suggestions}

Pastors who have experienced burnout can find support from CPE supervisors, professional counselors, or peers. Grieving pastors can likewise find help towards recovery. In this way, pastors are better equipped to do counseling, particularly in this context for grieving individuals.

Pastors in SDA churches, besides advocating fundamental beliefs, can find fulfillment by practicing 
biblical and pastoral-care principles in grief ministry. When Christ's methods of utilizing presence, empathy, forgiveness, and love, as He did to the woman caught in adultery (John 8:1-11), are correctly presented and applied, they can be helpful to pastors in grief ministry.

\section{Cultural Values in the Yin-Yang Concept}

One of the practical resources for grief ministry comes from appreciation of the cultural values of the community. ${ }^{1}$ In the Chinese community the Yin-Yang concept has been appreciated since the time of Confucius some 500 years before Christ. Although there are many philosophical concepts in the Chinese culture, the Yin-Yang concept has been selected for this project because the Yin-Yang concept is frequently cited in pastoral-care literature. Moreover, the Yin-Yang concept demonstrates an integrated imagery. The Chinese Yin-Yang depicts a picturesque, balanced, logical, and holistic system because the Chinese have "an ancient heritage of understanding persons and their healing more holistically."2 For example, light and darkness or day and night are considered Yin-Yang. According to Chinese thinking, when a person is sick, he/she is considered as having an imbalance of Yin-Yang. The ancient philosophers

${ }^{1}$ James D. Whitehead and Evelyn Eaton Whitehead, Method in Ministry (Minneapolis, MN: Winston Press, 1980), 31.

${ }^{2}$ Howard J. Clinebell, Jr., "Pastoral Psychology and Care in the People's Republic of China," The Journal of Pastoral Care, 40, no. 4 (1986): 376 . 
attributed the healthy equilibrium of the body to the complementary poles of Yin-Yang. Chinese medicine attempts to restore such harmony as a basis for cure. ${ }^{1}$

Even today, this belief influences the thinking of Chinese and other Asian cultures. Although Singapore has a multicultural context, the Chinese from the older generation, in their sixties or older, treasure some of these ancient teachings.

The next section presents the Yin-Yang Concept based on its imageries and symbols, its comparison with psychotherapy and cosmology, and some practical suggestions for grief ministry.

Imageries and Symbols

Some other examples of imagery, based on Yin-Yang, are found in Taoist symbols. The Chinese zodiac system of twelve animals, the mystery of the eight immortals, the compassion of the goddess of mercy, and the dynamics of the monkey god provide interesting lessons of cultural interest. The Chinese in Singapore can still find in bookstores literature containing traditional thoughts based on the Chinese Yin-Yang concept. ${ }^{2}$ Pastors can learn from these cultural values. It is not unusual to discover a Chinese parishioner who associates truth with Yin-Yang. For example, Chinese believe that the earth is $\underline{Y}$ in and heaven is 44 .

${ }^{1}$ Bill Moyers, "Mind over Malady," Time, March 1, 1993,

${ }^{2}$ Ethel R. Nelson, Mysteries Confucius Couldn't Solve (Dunlap, TN: Read Books Publishers, 1986), iv. 
Yang. Because heaven and earth are one, such belief can lead them to have faith in Christ who has gone to heaven to prepare a place for them (John 14:1-3).

The Chinese, mind is adaptable both to the abstract, or philosophical, and to visible symbols such as Yin-Yang. However, since Chinese characters are in reality pictographs, it is most appropriate to express biblical concepts in word pictures. For example, the chinese can understand Christ as a Shepherd who brings comfort and leads the grieving through the green pastures of 1 ife as well as the shadow of death (Ps 23). Similarly, the imagery of yin$\underline{Y a n g}$ refers to $\underline{Y i n}$ as death and $\underline{Y a n g}$ as life.

\section{A Narrow System Interpretation}

The Chinese Yin-Yang has a wide spectrum of meanings. The word yang refers both to centripetal force and the

\footnotetext{
${ }^{3}$ Murray Stein, Jung's Treatment of Christianity (Wilmette, IL: Chiron Publications, 1985), 149, 150, 175, 184 ; see also, Raymond J. Corsini and Contributors, Current Psychotherapies (Itasca, IL: F. E. Peacock Publishers, 1984), 118-119. Jung confined Yin-Yang to animus and anima only in contrast to its wider meaning. "Two central elements in Chinese philosophy are the Yin and Yang. The Yin represents the feminine principle; it is the world of nature, creation and life, earthiness and concreteness, receptivity and yielding, the dark and containing, the collective and undifferentiated, the unconscious. The Yang is its opposite--the masculine principle, the driving energy, the creative and initiating, the light and hot, the penetrating, stimulating and dividing, the principle of separation and differentiation, restriction and discipline, the arousing and phallic, aggression and enthusiasm, spirit and heaven." Although the wider meaning of the "Chinese Yin and Yang" is acknowledged, the focus of current psychotherapy on male and female could cause some limitations in understanding the original fuller meaning of "Yin and Yang."
} 
sun. ${ }^{1}$ The word $\underline{Y}$ in does not refer directly to the moon, but it does connote night. Yang is made visible by the sun, which gives light and rules the day. The Yin is made visible by the night when the moon reflects the light from the sun. In contrast to the broad meaning of Yin-Yang, psychotherapists have narrowed its scope in referring to genders. Jungians have limited $\underline{\text { Yin }}$ to connote feminine anima; and Yang to masculine animus as Jung advocated. In psychotherapy, Yin-Yang is limited to humanity, while YinYang refers to many objects and activities in the universe.

\section{Contextualizing Cosmology}

Chinese cosmology teaches that the existence of human beings is based on eternal love. For example, it has been taught that. "Heaven and Earth have existed for a long time. The reason they have been able to exist for so long is that they do not live for Self; therefore they can live for a long time." ${ }^{2}$ Such ethical principles embodies eternal value and unselfishness and are the basis for strong family ties. In this context the grieving persons find support.

The Chinese believe in the unity faith. This can

${ }^{1}$ I believe Yin-Yang also has a centrifugal aspect because the sun center has intense heat and light in comparison with those of distant planets.

${ }^{2}$ Laurence G. Thompson, The Chinese way in Religion (Encino \& Belmont, CA: Dickinson Publishing Co., 1973), 48. "Long time," here, means eternity. The focus is more on quality than on quantity. It connotates something that exists forever. 
be seen in ancient religious symbols found in $\mathrm{Zi}$ 'an, a city in central China, where famous archeological sites have been uncovered. It was here that the paths of religions met. In at least two locations in the vicinity of $\mathrm{Zi}$ 'an, a picture of the Lotus (Buddhism), the Cross (Christianity), and an Angel (Heavenly) were inscribed together. ' This picture portrays an acceptance of diverse faiths by traditional Chinese. This is an evidence that they believe in unity, love, and peace.

\section{Strengthening Family Values}

Most Chinese, whether traditional or modern, cherish family values. Families are believed to be the building blocks of society. The family is an economic and social unit, but the meaning of "family," in the Chinese sense, is difficult to describe in American or Western terms. Jernigan has noted:

"Family" is a kind of mythical entity that has meaning far beyond economic and biological ties. It is the primary context of the meaning of life. It has to do with a lineage that stretches far back into the past and will continue into the future. The current family and its members find their place within the lineage and contribute what they can to the ongoing welfare and reputation ("face") of the family."

Family is also the evidence of benevolence or Jen. In

${ }^{1}$ Smith, 11, 98 .

${ }^{2}$ Homer L. Jernigan, "Aging in Traditional Chinese Society," Journal of Reliqious Gerontology 8, no. 3 (1992): 20. 
Family is also the evidence of benevolence or Jen. In the Chinese character Jen ( $(=)$ has the components of a word "person" on the left and a number "two" on the right, representing the harmonious reaction of Yin-Yang. Just as in physics, the negative and positive ions in an atom give power. ${ }^{1}$ This Chinese concept describes such harmony in the universe. This harmony can be employed by pastors to describe the good and evil forces on this earth and the origin of sin from Lucifer/Satan (Ezek 28:17-19; Gen 2:1314) contrasted with love from God in heaven (Exod 54:8; Rev 12:7-8). This is the reason for the older Chinese turning to heaven in traditional worships. Perhaps, this was the entering wedge for missionaries to point individuals to the heavenly Father. This may have provided opportunity to teach them about the caring God. Yin-Yang may also illustrate the harmony of joy and sadness in grief--the good of them that love God in happy and in adverse circumstances (Rom 8:28). Pastors who are able to relate this blending in their grief ministry will appeal to the traditional Chinese. Furthermore, Yin-Yang, to a certain extent, can be taught to the Chinese as a symbol of Christ: Christ's life and death give and assure us of eternal life.

\footnotetext{
${ }^{1}$ David W. Augsburger, Pastoral Counseling Across Cultures (Philadelphia: Westminster Press, 1986), 166. Jen which means benevolence, is defined as a sympathetic heart. "Love of all human beings, respect for the prizing of true humanity. This love of others is rooted in love of parents, in filial piety."
} 
Practical Suggestions

Pastors may apply the following principles in grief ministry: (1) valuing relationships and respecting family units; (2) understanding their parishioners' personal backgrounds; (3) utilizing rituals such as bowing (a sign of respect in Asian cultures), which provide the bereaved with familiar imageries; (4) harmonizing the grieving process with Bible principles, (5) recognizing the inclusive meaning of Yin-Yang, and (6) utilizing festivals, like the Lunar New Year, to make pastoral visits. These are emotional periods when losses are commemorated.

Another area where the Yin-Yang concept can be effectively applied is in theology. The "either/or of theological thinking" is prevalent in the Christian world, and is responsible for many of the differences among Christian denominations today. ${ }^{1}$

Often, the differences have resulted in fractured relationships, hurts, and grief. The harmonized model of Yin-Yang can be a pattern for a change of attitude towards acceptance that can restore broken relationships. Harmony and inclusiveness are basic in pastoral care.

${ }^{1}$ Jung Young Lee, "The Yin-Yang Way of Thinking," International Review of Missions, 60 (1971): 362-366. The symbol of Yin and Yang is the primordial category of everything that exists in the world. The characteristic nature of this symbol is not the conflict but the complementarity of opposites. It is the category of becoming, rather than of being. It is the transcending categories of our rational thinking. It is therefore possible to express divine nature or methods of healing that transcend every dichotomy and the conflicts of opposites. 
Since it has some similarities with certain biblical

concepts, its inclusiveness compares with Christ's teaching of loving our enemies (Matt 5:43-47).

\section{Development of Self within the Pastoral Perspective}

One of the components in the formation of a holistic pastoral perspective is the focus on self as an "instrument." Here self is not regarded as the center of attention, but as an agent for service to others. This necessitates an analysis of how pastors personally and spiritualiy grow in the formation of a holistic pastoral perspective in grief ministry.

\section{Personal and Spiritual Dimensions}

Personal and spiritual dimensions in pastoral education often focus on the pastor as a person. Schoun asserted, "Truly, among all the things that ministers are, they are first of all human beings." 2 This is in contrast with what some congregations do: they place pastors on a high pedestal. In such an aloof position pastoral growth is jeopardized. However, when pastors live at the human level, to where successes and failures are reflected on, growth often can be facilitated. Tiller said, "The intrapersonal is accessed through exploration of personal history, which, once clarified, provides a reliable reference point for the understanding of interpersonal dynamics along parallel

\footnotetext{
${ }^{1}$ Tiller, 147.

${ }^{2}$ Schoun, 6 .
} 
once clarified, provides a reliable reference point for the understanding of interpersonal dynamics along parallel. 1 ines." 1

This means that if pastors uncover their past hurts in order to facilitate healing, their parishioners may more easily do likewise. It is also essential for pastors to integrate their experiences within biblical and contextual perspectives. For example, pastors can grieve like David who lost his son or like Job who lost everything. Under trying circumstances, an appropriate question can be asked: How can a pastor's ability to cope with grief be helpful in ministry? The ability to cope with experiences of loss and suffering in ministry can enable him/her to be more sensitive to others in coping with their grief and growth in faith $(2$ Cor $1: 3-4)$.

\section{Developing Relationships}

A caring relationship between the pastor and his/her members sometimes develops during the suffering in times of loss. Healthy relationships promote growth and positive self-esteem between pastors and members. Fractured relationships often result in chaos, confusion, and destruction. These destructive elements, if unresolved, hamper the ministry of pastors. In order to encourage healthy relationships, pastors and parishioners must answer the "call to develop the human potentialities to the fullest

\footnotetext{
${ }^{1}$ Tiller, 149.
} 
through ongoing education." ${ }^{1}$ Grief ministry is a relatively new concept in Singapore and requires the education of its pastors in order to introduce it to the people of Singapore.

\section{Integrated Perspective}

An integrated perspective in pastoral education is essential in order to develop a loving and caring ministry. This integrated perspective results in an integration of the three major components of ministry: theological teachings, cultural concepts, and personal experiences. ${ }^{2}$

In order to utilize personal experiences to facilitate healing and growth, pastors are encouraged to reflect on the implications of their personal experiences, particularly in their childhood, when events are most significant in shaping the character.

The concept of a person's early childhood influencing the rest of one's life is biblical. The Bible provides reflections of childhood in the lives of Jesus and Timothy. Jesus' childhood is presented as a holistic development of His growth in Luke $2: 40$. Timothy's early years were nurtured with spiritual care by his grandmother, Lois, and his mother, Eunice ( 2 Tim 1:5). Recalling events in childhood, adolescence, and adulthood can contribute much to

${ }^{1}$ Henri J. M. Nouwen, Creative Ministry (Garden City, NY: Doubleday \& Company, 1971), 3.

${ }^{2}$ Whitehead and Whitehead, 97. 
the meaning of one's life. Through the reflection of such events, one's attitude can be reshaped. When pastors reflect on their past experiences within the context of their life situation, they can better help parishioners explore the meaning of their life events. In theological parlance,

the minister challenges the parishioner to interpret this event in the light of what he or she holds sacred. The pastor invites interpretation of this and other events of the parishioner's history, in the light of the conviction that the Divine is active in the affairs of the particular and mundane. This event may shatter inadequate myths by which one has lived. It may serve as a parable that challenges particular directions in one's life. It may be another act in a continuing drama that needs attention. ${ }^{1}$

\section{Growth in Pastoral Skills}

As a result of integrating theology, culture, and personal history, many pastors grow personally and professionally. This principle was demonstrated by the founder of CPE.

Boisen was a respected scholar and ahead of his time in attempting to integrate the intellectual and emotional aspects of life through the use of an empirical approach to study the psychology of religious experience. ${ }^{2}$

A pastor's spiritual growth and personal development are continuous processes in his/her life. Growth and

${ }^{1}$ Mark Jensen, "Life Histories and Narrative Theology," in The Supervision of Pastoral Care (Louisville, KY: Westminster/John Knox Press, 1989), 117.

${ }^{2}$ Charles E. Hall, Head and Heart (Decatur, GA: Association of Clinical Pastoral Education, 1992), 11. 
professional development includes the following personal and professional aspects: Communication and personal gifts.

Communication

There is a need to sharpen pastoral language. Pastors who articulate the feelings of parishioners through appropriate language and responsible actions reflect their sensitivity to human needs and become receptive to the love of God. ${ }^{3}$

Pastors can improve their ministry to grieving persons by sharpening their communication skills. For example, by providing more accurate spiritual assessment, ${ }^{2}$ pastors suggest goals to parishioners to help them obtain insights to work towards recovery. Clearer communication during pastoral visits will also bring parishioners comfort.

Personal gifts

The pastor's awareness of his/her unique personal gifts is important. Each pastor has unique gifts and an individual personality. God has a special ministry for each one to perform. ${ }^{3}$ However, personal gifts need assessment.

${ }^{1}$ Holmes, 109 .

${ }^{2}$ Chor-Kiat Sim, "Pastoral Diagnosis of Patients with Disability," Journal of Religion in Disabilities and Rehabilitation 2, no. 3 (1995): 42-50.

${ }^{3}$ Roy C. Naden, Your Spiritual Gifts (Berrien Springs, MI : Instructional Product Development, 1989), 21 .. 
The assessment of gifts can help pastors to serve at their optimum capacity. Furthermore, the integration of cognitive and affective components is essential in developing a holistic pastoral perspective for pastors in grief ministry $\cdot^{1}$

\section{Holistic Pastoral Perspective}

The development of a holistic pastoral perspective in grief ministry requires the integration of the following cognitive and affective components (see figure 1):

1. Cognitive Components: Bible, theology, and education. These components are considered to be cognitive because they are understood through the intellect rather than emotions.

2. Affective Components: Personality, culture, and relationship. These components are considered to be affective because they are connected closely with the experiential and emotional aspects of life.

In His earthly ministry, Christ demonstrated the blending of cognitive and affective components through words and action. For example, Christ instilled a holistic perspective in the minds of the disciples during the footwashing ceremony He instituted (John 13:6-12). By humbling

${ }^{1}$ Barry K. Estadt, ed., The Art of Clinical Supervision (New York: Paulist Press, 1987), 13. 


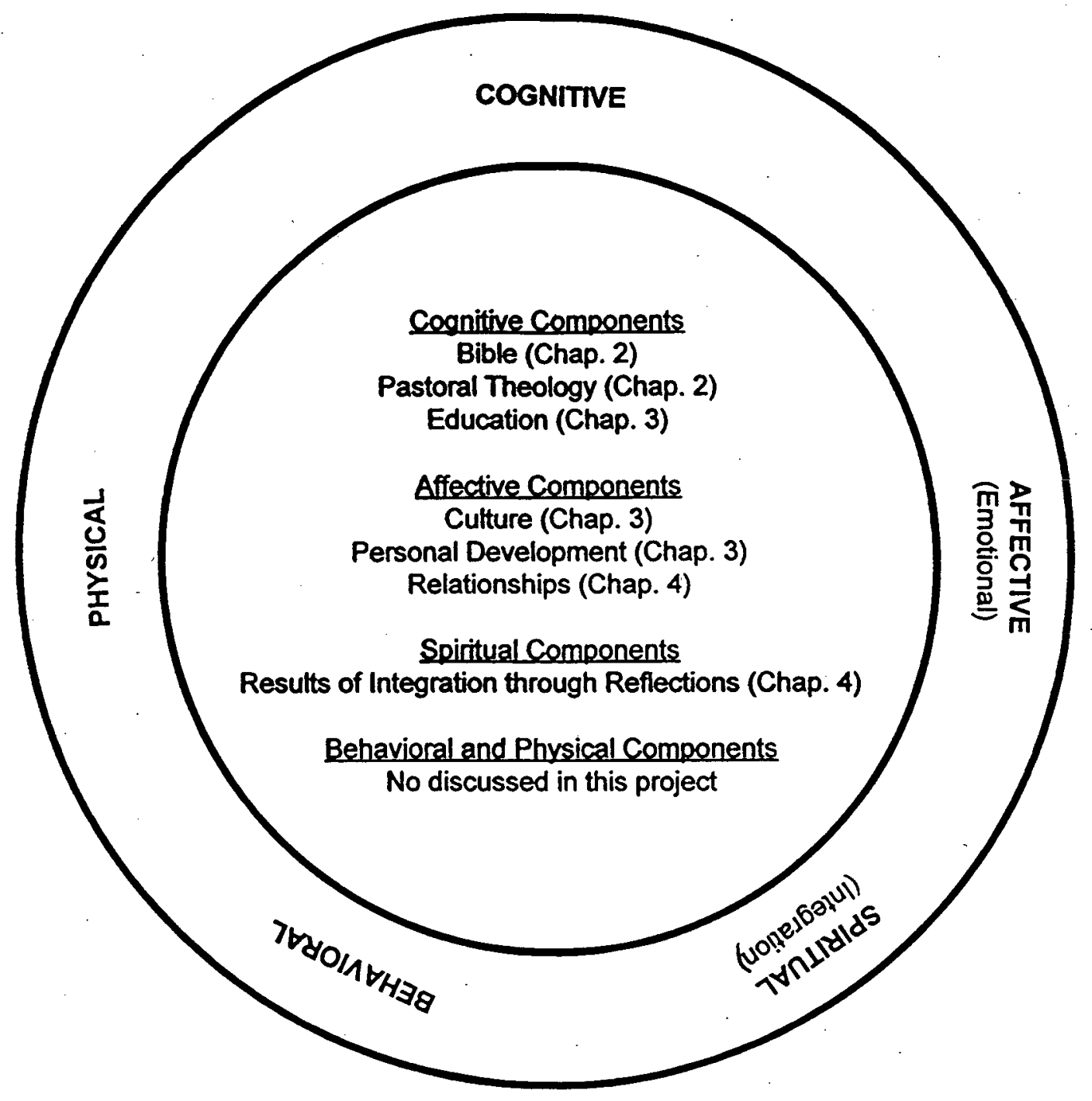

Figure 1. The components of a holistic pastoral perspective. 
Himself to wash the disciples' feet and the subsequent command on wholeness, He touched the affective level and lessened the resistance of Peter (John 10:6-9). On the cognitive level, Christ explained to him along with the disciples the difference between partial involvement (John 13:8) and wholehearted consecration symbolized by footwashing, which was the outward evidence of the cleansing of the whole body (John 13:10). The ordinance of humility instituted by Christ in the Upper Room was a demonstration of Christ's advocacy of integration in anticipation of their impending grief when Christ was crucified. Christ was preparing His disciples for the unexpected shock when death separated Him from them. This holistic perspective provides an impetus towards recovery in facing the pain of separation and loss. In many other instances in the Gospels, Christ demonstrated the value of integrating cognitive and affective levels. This is the model whereby I propose to train pastors in grief ministry (see figure 1).

When the various components of the holistic pastoral perspective are well-understood, they merge together to facilitate a clear understanding of pastoral roles in grief ministry. In this way, their own integration allows pastors to interact more positively with parishioners. 
Holism is also important in Schneider's grief recovery program. He found that if suffering persons integrate the holistic dimensions of the transforming process ${ }^{1}$ of grief, they will experience healing.

Christ's woundedness that heals humankind (Isa 53:5) and Paul's endurance in suffering and coping with losses ( 2 Cor 4:8-12) provide images of how a pastor who endures and copes with grief can influence his parishioners. In the modern sense, as a result of such integration, positive imageries can strengthen the immune system and the will of patients $^{2}$ (see figs. 1-3). In order for pastors to lead out in the holistic process, their own integration of cognitive and affective components must be ongoing and must be modelled in order for parishioners to work towards recovery. For example, one of the professional hazards of pastoral ministry is changing parishes frequently. If pastors develop principles on how to make adjustments with new environments and to cope with changes in transitions, parishioners can then benefit from their coping models. Pastors will have better success as comforters if they are living a holistic pastoral perspective.

${ }^{1}$ Schneider, 230. Schneider stated that "grief is a process of such transformation" because it accounts for experiences that move from stagnation to growth, attachment to freedom, and debts to gifts (ibid.).

${ }^{2}$ Ibid., 237. 


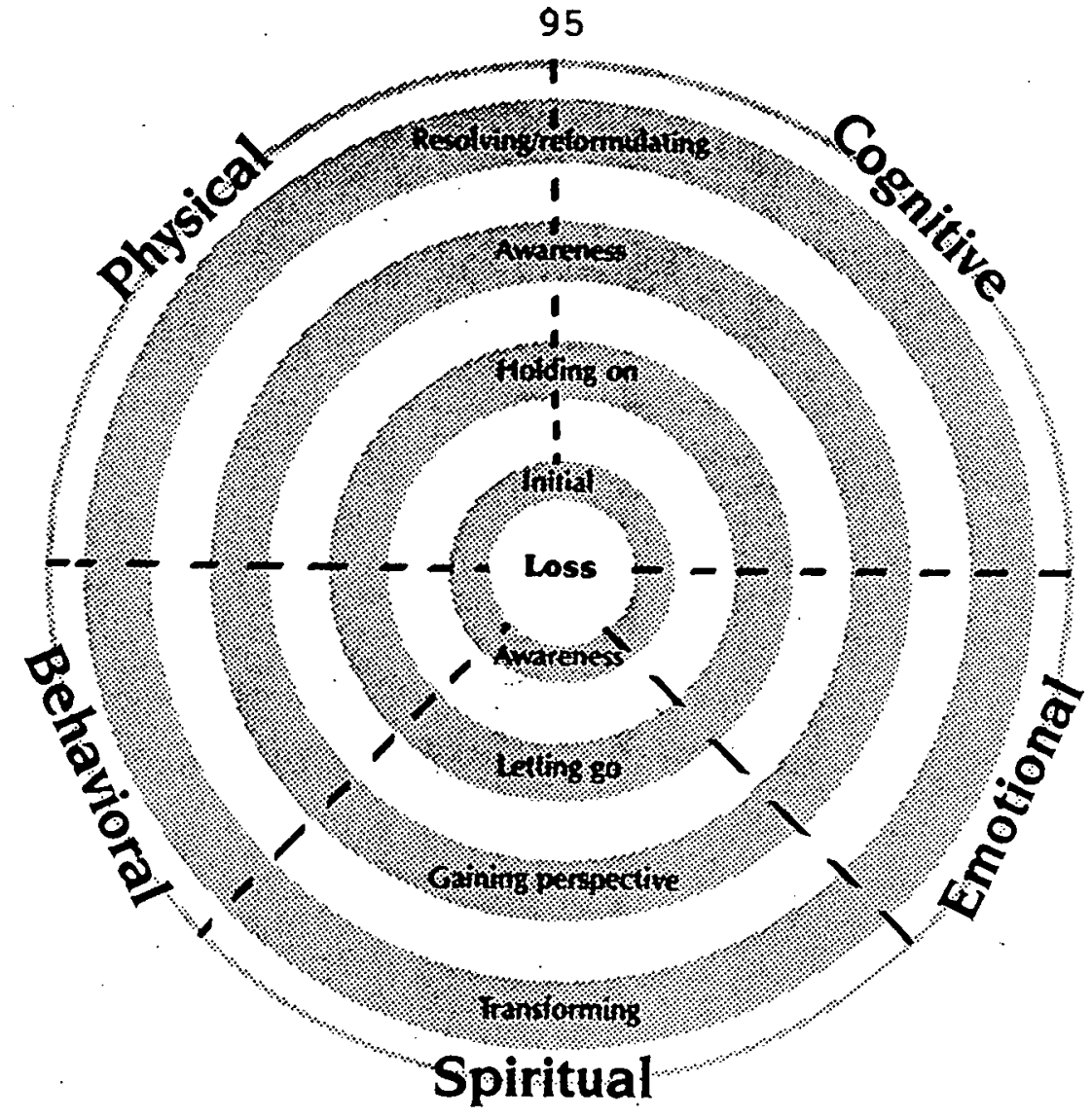

Figure 2. Fragmented dimensions before grief work has taken place. Lines represent barriers between dimensions; losses segregate the various dimensions. Source: John Schneider, Stress, Loss, and Grief (Baltimore, MD: University Park Press, 1984), 105.

Several phases mark the nature of bereavement as. shown in figure $2 .^{1}$ The phases are isolated as a result of the loss. The intensity and length of any phase vary between individuals. ${ }^{2}$ When these dimensions are disconnected, the human system breaks down. However, when these dimensions are connected by pastoral. support, recovery begins.

\footnotetext{
${ }^{1}$ Ibid. . 105.

Ibid. , 67.
} 


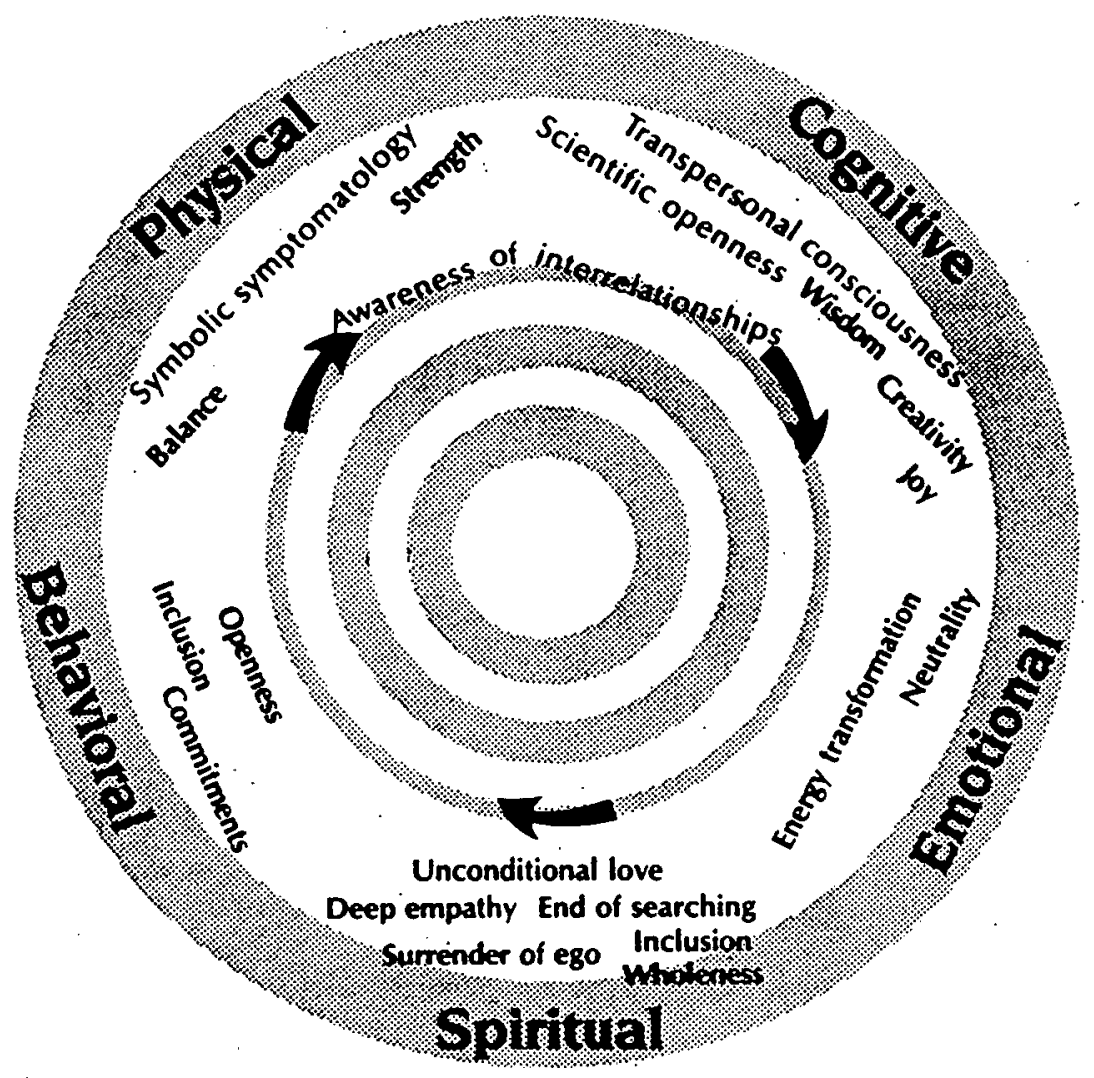

Figure 3. Holistic transformation in dimensions of grief shows healing is taking place within a person. Absence of lines between phases represents integration of various dimensions during the recovery process.

Figure 3 demonstrates a holistic transformation in various phases of grief.' A person's potential for healing is manifested when those grieving think holistically. It has been shown that 75 percent of those with effective imagery had no further progress of the disease. ${ }^{2}$

\footnotetext{
${ }^{1}$ Ibid., , 236.

${ }^{2}$ Ibid.
} 
It has been substantiated: "100\% of those whose imagery showed the cancer to be a more powerful force than the immune system had gotten worse or died in the next 2 months." 1

\section{Practical Suggestions}

There is a parallel process between pastors' personal and professional development and their parishioners' ability to be healed. When pastors are sure about their pastoral perspective and live it, the members will also experience wholeness.

\section{Conclusion}

Pastors can be effective in grief ministry if they develop a holistic pastoral perspective. This holistic pastoral perspective is developed by utilizing practical resources in (1) identifying their roles within a sound understanding of God's images, (2) participating in CPE in the context of theological education, (3) utilizing cultural values $^{2}$ such as the Yin-Yang concept, and (4) integrating personal development. An ongoing study of the Bible, pastoral theology, education, culture, personal development and relationships also equips the pastor to develop a holistic pastoral perspective for grief ministry.

\footnotetext{
${ }^{1}$ Ibid.

${ }^{2}$ Kathleen Ogden Davis, "Working with Clinical Material," in Supervision of Pastoral Care (Louisville, KY: Westminster/John Knox Press, 1989), 113.
} 
CHAPTER IV

INTERVENTION

Introduction

The term intervention refers to a process through which events, or a series of events, will break through the dynamics of an individual or group of individuals at personal and/or corporate levels in order to bring about a re-evaluation of one's motivation, sense of purpose, and direction,' ${ }^{2}$ and positive change.

In this present chapter, I briefly attempt to:

1. present a biblical foundation for the principle of intervention

2. evaluate the benefits of intervention both at an intra-personal as well as an inter-personal level

3. outline the stages of a pastoral training retreat, focusing on relationships. This retreat will feature the four seasons as a process framework:
a. Autumn Session (implies dying)
b. Winter Session (implies death)
c. Spring Session (implies grief recovery)
d. Summer Session (implies life anew).

${ }^{1}$ Cf. Ralph L. Underwood, Empathy and Confrontation in Pastoral Care (Philadelphia: Fortress Press, 1985), 89118. 


\section{Biblical Foundation for Intervention}

Many examples of the principle of intervention are found in the Scriptures. For instance, there were periodic interventions in God's interaction with His people: when God intervened by announcing to Adam and Eve in Eden the plan of redemption after they sinned (Gen 3:13-15); God delivered the Israelites from Egyptian bondage and idolatry (Exod 2:23-25); and, God intervened to deliver His people from their enemies ( 2 Sam $22: 1-4$ ).

God intervened, not only at the corporate level, as described above, but He also interposed on a personal level. God appeared in the burning bush while Moses was shepherding his flock in the wilderness (Exod 3:1-14). God appeared to Gideon while he was threshing wheat in the field (Judg 6:1140). He called numerous prophets from their labor to prophetic ministries (Jer 1:1-5; Ezek 1:1-3; Dan 1: 19, Amos 3: 7, etc.) Likewise, in the New Testament, Christ intervened in the lives of fishermen to call them to discipleship (Matt 4:18-22). He interrupted Paul's travel along the Damascus Road to call him to apostleship (Acts 9:10-19). There are a multitude of biblical examples.

These exemplary events of intervention can provide a basis for confidence and faith when pastors are confronted with unusual events in their pastoral work. The purpose of the spiritual retreat is to encourage pastors to be more sensitive to grief. The retreat is a means to increase the 
pastors' ability to deal with pain instead of using the tactic of avoidance. ${ }^{1}$ It is hoped that pastors will come to terms with their own mortality by filling in the "Inventory of My Response to Death" (see Appendix E) and by telling their stories, similar to how Paul urged his followers to examine themselves ( 2 Cor 13:5).

\section{Intra-personal Dynamics of}

\section{Intervention}

Christ called His disciples to balance time for introspection (Mark 6:31) with service (Mark 10:45). Selfcare should be balanced with caring for others. Understanding such a dynamic is important to survival in ministry. ${ }^{2}$ Lutz and Taylor speak of the tendency of neglecting self-care while doing pastoral duties: "Self-care of one in ministry has been addressed only indirectly as far as I can ascertain. " ${ }^{3}$ They further emphasized that shepherding in ministry does not require neglecting adequate self-care. ${ }^{4}$ Self-care is often preceded by self-discovery. In order to facilitate the process of self-discovery, intrapersonal reflection is divided into two categories: (1) the spiritual aspect, and (2) the emotional aspect.

${ }^{1}$ Everitt L. Shostrom and Dan Montgomery, Healing Love (Nashville: Abingdon Press, 1978), 54. Shostrom and Montgomery identified tactics used by some Christians such as manipulation, withdrawal, and avoidance to escape the demands of responsible growth and self-direction.

${ }^{2}$ Robert R. Lutz and Bruce T. Taylor, Surviving in Ministry (New York: Integration Books, 1990), 2 .

${ }^{3}$ Ibid.

${ }^{4}$ Ibid. 
Spiritual aspects

In the hectic pace of a cosmopolitan city such as Singapore, ministers need to find time to discover God's input into their lives. This retreat will provide time for pastors to reflect on their feelings by writing their personal stories. Such introspection will provide opportunity for every pastor to be reminded of the following spiritual lessons:

1. Grief finds healing at the cross. Indeed, each true mourner, in order to be healed, must come to the foot of the cross "in brokenness of heart." 1

2. Pastors should also seek to nurture in themselves a spirit of humility. Humility is an essential attitude that facilitates healing from separation in human events in times of loss. It facilitates a restoration of relationships with other fellow human beings, as well as one's personal relationship with God. ${ }^{2}$

3. Pastors, like parishioners, are created in God's image. Lutz and Taylor recommended:

Perhaps another approach to ministry by modeling could be suggested based on the belief that we are created in God's image and that God was pleased with what was created. I have in mind a model which will provide the latitude to grow towards being the unique people God made us to be, the space to take adequate care of ourselves in order to stay healthy in ministry, and the example for those we are called to serve that will be life enhancing. ${ }^{3}$

\footnotetext{
${ }^{1}$ White, Thoughts from the Mount of Blessing, 10 .

${ }^{2}$ William A. Barry and William J. Connolly, The Practice of Spiritual Direction (New York: Seabury Press, 1983), ix.

${ }^{3}$ Lutz and Taylor, 6 .
} 
The above idea resonates with the image of God and pastoral identity in this project. Lutz and Taylor gave a kind of poetic picture:

Whole person,

Empowered by God's image,

To live and serve authentically, and

Be freed by that grace to accept our limits.'

The recognition of the whole person empowered by the biblical image of God is the basis for a caring ministry.

Emotional aspects

Whereas intervention allows for the recognition of the spiritual aspects, one should also acknowledge the importance of emotional healing in grief ministry. Some knowledge about the life cycles common to human beings is helpful in analyzing different periods in a person's life. According to Erickson, ${ }^{2}$ the emotional journey of an individual can be categorized into eight stages, each of which consists of virtue and/or psychosocial crisis. The psychosocial crises are as follows: basic trust versus basic mistrust (ages 1-2), autonomy versus shame and doubt (ages 2-3), initiative versus guilt (ages 3-5), industry versus inferiority (ages 6-12), identity versus identity confusion (ages 12-18), intimacy versus isolation (ages 1935), generativity versus stagnation (ages 35-65), and integrity versus despair (age after 65$).^{3}$ (See Appendix I.)

\footnotetext{
${ }^{1}$ Ibid.

${ }^{2}$ Erikson, $32-33$.

${ }^{3}$ Ibid.
} 
Retrospectively, the resulting virtues are: hope, will, purpose, competence, fidelity, love, care, and wisdom. ${ }^{1}$ Similarly, Cook and Moorehead have identified the following six stages in a pastor's life: ${ }^{2}$

1. The post-seminary period (after graduation from seminary-no exact age specified)

2. Beyond the first parish (age in the early 40s)

3. The forks in the road (about the late 40s)

4. The best years (age ranges from 45-55)

5. Pre-retirement (age ranges from 55-65) and

6. Retirement (age after 65).

Each stage has a particular virtue or crisis. Since most pastors in Singapore are adults at their "best years," identifying some of the issues common to this stage is most appropriate. This caring stage involves the period when both pastors and parishioners come to terms with their mortality. This accounts for the use of "Inventory of My Response to Death" in the retreat to invite participants to come to terms with their own death.

Cook and Moorehead also identified some "potentially threatening episodes" in the "best years." ${ }^{3}$ These are,

${ }^{1}$ Ibid.

${ }^{2} \mathrm{~J}$. Keith Cook and Lee C. Moorehead, Six Stages of a Pastor's Life (Nashville, TN: Abingdon Press, 1990), i1. For dynamics of other life stages, pastors can refer to the same book.

${ }^{3}$ Ibid. 
1. Experience of Deep Hurts: A professional hazard can be the loss of self-esteem by derogatory words.

Pastors can be easily hurt. Biting criticism can hurt, especially when it is perceived to be unjust. Prominent leaders who defect from the church cause deep pain. The rejection by officials of a carefully prepared plan for church programming can fill one with dismay."

Furthermore, he adds, "though it may seem paradoxical, a pastor's best years can be realized in time of crisis." 2 Recognizing these crises with their joys and pains can be a step towards real life because most people have inner resources to cope $^{3}$ when their uniqueness and critical issues are denied.

2. Green-eyed Monster of Covetousness: Cook and Moorehead urge pastors to recognize the sacrifices they have. to make in accepting a calling rather than a career. They state that "to fight off the demons of covetousness will require a new understanding of the ministry as a calling." * Pastors tend to covet "things" when they fear that they are not keeping up with some parishioners. Such new understanding can be obtained when a holistic pastoral perspective is obtained: when life is more than what it appears to be in terms of external and material aspects of life.

\footnotetext{
${ }^{1}$ Ibid., 76.
}

${ }^{2}$ Ibid.

${ }^{3}$ Williams and Sturzl, 69, who emphasized the importance of relationship with God here.

${ }^{4}$ Ibid. , 79-80. 
3. Loneliness: The feeling of loneliness drives many pastors away from the ministry. To overcome loneliness, a pastor can network with younger pastors and continue a growing relationship with family members. "In authentic acts of graciousness and generosity, the loneliness of the long-distanced pastors may be mitigated."1

A personal understanding of pastor's life stages and inner human dynamics may lead pastors to a clearer understanding of their intra-personal and inter-personal relationships.

\section{Inter-personal Dynamics of Intervention}

Intervening in pastoral routines as the retreat provides can be put into two categories: (1) Individual responses, and (2) Corporate responses.

\section{Individual responses}

Individual responses operate both at emotional and psychological levels: Each individual is born with emotional feelings which inter-play, according to circumstances, with the pastors' own history and education." When losses are accompanied by a feeling of guilt, people may become discouraged, bored, and/or depressed. ${ }^{3}$ These responses

${ }^{1}$ Ibid., 80. "Long-distanced" pastors refers to pastors whose churches are far apart.

${ }^{2}$ R. E. Puff, "Emotional Development," Dictionary of Pastoral Care and Counseling (1990), 352-354.

${ }^{3}$ Barry and Connolly, 80 . 
inevitably affect one's communication skills and hinder inter-personal relationships.

Psychologically, a person's attitude toward another depends upon his/her own genetic and biochemical makeup. ${ }^{1}$ These biological components in a person's life directly affect his/her emotional responses to others. One of these components is attitude. The formation of one's attitude comes from an accumulation of experiences since childhood. For example,

a man who has a highly ambivalent relationship with his mother might have only two categories for assimilating women who enter his life: loving and yielding or hating and demanding. ${ }^{2}$

The perception a pastor has as a result of negative life experiences with a certain object or person can create resistance to that object or person. It is necessary for such resistance "to be uncovered" to maintain a healthy relationship with some colleagues and parishioners.

Corporate responses

Corporate responses to intervention involve such dynamics as mutual support in pastoral fellowship. The individual and corporate self-esteem of those sharing a common goal will become the basis for such a team spirit.

${ }^{1}$ A. J. Straatmeyer, "Theories of Psychopathology," Dictionary of Pastoral Care and Counseling (1990), 1011.

${ }^{2}$ Barry and Connolly, 85 .

${ }^{3}$ Ibid. , 100 . 
Corporative bodies should take into account their physical, emotional, and spiritual aspects.' By having mutual trust and better communication, closer relationships will be developed. Through mutual respect, courtesy will be expressed among one another. There will be closeness in relationships." "Strong team spirit in team members seems to be based on positive self-esteem and esteem of team members" who share a common goal. ${ }^{3}$

Browning states: "Communication transcends the singular event and its circumstances. Communication is a process whereby individuality and community are formed." 4 The natural surroundings at a retreat center contributes to communion with God and communication with one another towards a better relationship. Thus major objectives of the retreat may be fulfilled. The retreat, consistent with the holistic concept, will develop a sequence of concepts that may be identified by the following acronym:

G -- God's Images

$\mathrm{R}--$ Relationships

O - Open-mindedness

W - - Word of God

$T$-- Truth of one's potential

$\mathrm{H}$-- History of Persons
The Creator and Redeemer Communication with God Inclusiveness Biblical Doctrines

Spiritual Gifts Culture/Personal Development

${ }^{3}$ J. L. Florell, "Interprofessional Teams and Relationships," Dictionary of Pastoral Care and Counselling, (1990), 593 .

${ }^{2}$ Ibid., 594.

${ }^{3}$ Ibid.

${ }^{4}$ Underwood, 48 . 
Through the intervention of the spiritual retreat, the vision of grief ministry getting more focused. There will be an exercise of writing a short autobiography in the context of grief and plans for grief ministry. The writing process tends to facilitate the dynamics of coming in touch with one's hidden pain.

\section{Objectives of Growth Retreat}

Having in mind the holistic concept, the objectives of the, retreat are 1 isted below:

1. Relationships: To provide further growth of pastors in relationship with God and their fellow human beings through active participation

2. Pastoral Qualities: To further develop the pastoral qualities of genuineness, honesty, and faith through sharing participants' life stories

3. Dynamics of Grief: To further understand the dynamics of grief in pastoral care, through participation in the exercises

4. Life-story Re-written: To rewrite one's story based on the holistic pastoral perspective (theological, biblical, cultural, education, personal and relational respects) in this project ${ }^{2}$

${ }^{1}$ Jensen, 125. "One of the major purposes of looking back is to perceive what was not only recalling but reordering our perceptions about the past and its meaning for the present" (ibid.).

\footnotetext{
${ }^{2}$ Ibid.
} 
5. Felt Needs of Persons: To meet the felt needs of pastors, parishioners, and the community through grief ministry plans.

In essence, the retreat proposes to invite pastors to be aware of their human needs and to acknowledge God as One who creates and re-creates. The insights gained from feeling pain may be enhanced by personal reflection and participating in other retreat activities. The most important requirement will be individual written proposals for grief ministry.

Integrative Role of the Growth $\underline{\text { Retreat }}$

The retreat will be titled the Seasons of Growth Retreat. This name is chosen because the retreat connects with nature and facilitates growth. The Seasons of Growth Retreat is organized to integrate cognitive and affective components. Each season has its respective meaning:

1. Autumn--Focus on reflections and grief

2. Winter--Focus on reality of dying and death

3. Spring--Focus on grief recovery

4. Summer--Focus on living life anew.

The Seasons of Growth Retreat will be conducted in this order:

1. It begins with Autumn because it provides the picture of a falling away, whether it be leaves or the passing of time. Autumn is a time to anticipate endings and the grief that may follow them. 
2. Winter is the time to face the stark reality of death as seen in nature. In death, warmth seems to have gone. Grieving is inevitable.

3. Spring reminds one of resurrection: something that has been dead, like seeds, is coming to life. It also reminds the grieving person of his or her gradual return to normalcy. Therefore, reformation and renewal take place. Spring is the time for planning--a time to plan toward recovery and to experience hope.

4. Summer portrays life, warmth, revival, and enthusiasm--the resumption of normal life after grief recovery. In summer, there is also rest from overexhaustion. Such peaceful repose and trust in God create revival.

\section{Guidelines}

This retreat can be conducted in four consecutive sessions on a weekend or in four weekly sessions. If it is conducted over the Sabbath, the leader should arrange it so as not to conflict with the Sabbath School and main worship service. Each session will last about three hours. All exercises are to be kept strictly confidential. The meetings will be conducted on an individual, one-to-one, small groups and whole group bases. This utilizes the spiritual discipline model of Paul (Eph $2: 6,4: 1,6: 6){ }^{1}$

\footnotetext{
${ }^{1}$ Charles M. Liu, "A Spiritual Model for Recovery of Pastors Suffering Burnout" (D.Min. project report, Andrews University, 1991), 42 .
} 


\section{Conclusion}

The intervention of the spiritual retreat enables the pastors to find time for reflection and planning in grief ministry. In doing so, each may examine his/her relationship with God, his/her relationship with one's self, and his/her relationship with others. There will be time at the end of the final session for suggestions, feedback, and a proposal for the next retreat. 
CHAPTER V

SUMMARY AND CONCLUSION

\section{$\underline{\text { Summary }}$}

This research project proposes to provide suggestions to train pastors for grief ministry. In order to do so, an introduction to the development of a holistic pastoral perspective by each pastor has been proposed.

The basic attempt in this project was to research from various disciplines both principles and practices of grief ministry, and to integrate theory with practice to provide a training program for pastors. The method recommended in this project is the retreat.

This project has blended the aspects of Being, Knowing, and Doing. Being has been explained in chapter 2, recognizing the formation of pastoral identity by relating to the images of God. The study of creation, death, resurrection, and grief has been made from some key texts with a focus on the images of God. Knowing has been amplified in chapter 3 by studying the four components: (1) pastoral roles, (2) education according to $\mathrm{CPE}$, cultural values as in the Yin and Yang concept, and (4) personal development through the understanding of spiritual gifts and human development. As for Doing, a spiritual retreat has been proposed in chapter 4 with stories and exercises. 
In the process of attaining competence, pastors should acknowledge intra-personal dynamics. Keidel, who spent three years in Singapore, said, "Emotional attitudes lag behind changes in social [conditions] in the development of a new nation."1 ${ }^{1}$ The gradual formation of a Singaporean identity through emotional maturity paves the way to cope with changes and grief. Singapore has undergone rapid economic progress, and Singaporeans have experienced great stress. Coupled with Westernization, Singaporeans are in identity crisis. These conditions drive pastors to look more intently to their own personal and professional crises and what practical resources the church may offer through fundamental beliefs, culture, personal development, and life narration. With regard to life stories, there are three cases in this project (Appendices L2, L3, and L4) to illustrate how narratives can help others in the grief process. Another story is found in chapter 3 page 69 of this project, which demonstrates how E. G. White coped with the loss of her husband through her hope in Christ.

In chapter 4, Erikson's eight stages of development in the human life have been highlighted. Human development specialists correlate these stages with the eight virtues in

${ }^{1}$ Keith W. Keidel, "Cross-Cultural Clinical Pastoral Training in Singapore," The Journal of Pastoral Care 27, no. 2 (1973): 114. Keidel also identified the tension between activitists and meditationists. He advocated to the Westerners to learn of the reflective style as "an attractive or shelter from the heat of chaos and the uncertainty of change." 
life: hope, will, purpose, competence, fidelity, love, care, and wisdom. Erickson advocates that these virtues should be integrated in a person's spiritual development in order for one to become a growing human person. ${ }^{1}$

It would be prudent for ministers to develop a holistic pastoral perspective, in this case, for their grief ministry. Pastors are encouraged to take time to reflect on their pastoral growth by taking the pre-retreat evaluation and Death Inventory before participating in the retreat.

Regarding pastoral preparation for ministry, White advocated: "My message to ministers, young and old is this: Guard jealously your hours for prayer, Bible study and self examination." ${ }^{2}$ It is through a close relationship with God and reflection that pastors grow to the extent where they are able to cope with grief.

\section{Recommendations}

The following recommendations are suggested:

1. A SDA theology of grief should be identified, researched, and introduced.

2. A focus on pastoral-care activities, such as endof-life issues within the context of the doctrines of the church, would encourage pastors in Singapore to engage in grief ministry.

\footnotetext{
${ }^{1}$ Linn, Fabricant, and Linn, 14.

${ }^{2}$ White, Gospel Workers, 100 .
} 


\section{5}

\section{Conclusion}

This project has presupposed that "Knowing," "Doing," and "Being" make us effective ministers. This presupposition integrates biblical studies, CPE, cultural considerations, and personal experiences. A spiritual retreat as a short-range program has been designed to introduce the integration of cognitive and affective components in a holistic pastoral perspective.

This project has dealt with biblical studies on God's images in creation, death, and resurrection in grief as contextualized in the culture of Singapore. Biblical studies, guided $\mathrm{CPE}$, and contextualization form the essence and foundation of the proposed training program in grief ministry for pastors in Singapore.

It further prompts pastors to clarify their own pastoral identity and pastoral roles in order to train them to be more sensitive to their own grief and that of the parishioners. Thus, pastors will be more competent and efficient in the grief ministry.

\section{Personal Postscript}

God has blessed my training at Andrews University and CPE program (1991-1995). I have trained five pastors/caregivers in basic CPE through the supervisory 
program while I have been writing this project. These five students were trained in one-and-a-half years' time while I continued my resident CPE chaplaincy. I am also supervising five seminary students under the auspices of North America Division Evangelism Institute (NADEI) in 1994 and 1995. These opportunities for doing supervision provided me with additional practical training for this project.

At this time, my former colleague, whom I referred to in the introduction, has expressed his gratitude to me for helping him to deal with grief in his life. He has completed a year of the CPE program with me and was ordained as a pastor on June 3,1995 , at the Kokomo SDA Church in Indiana. (See Appendix E.)

Part of my future ministry will be to conduct grief ministry. I will continue to be a pastor and pastoral educator. I am committed to continue grief ministry by conducting spiritual retreats based on the biblical principles of this project. 
APPENDICES 
APPENDIX A

MISSION STATEMENT OF THE SEVENTH-DAY

ADVENTIST CHURCH 


\section{MISSION STATEMENT \\ OF THE SEVENTH-DAY ADVENTIST CHURCH}

\section{Our Mission:}

The mission of the Seventh-day Adventist Church is to proclaim to all people the everlasting gospel in the context of the three angels' messages of Revelation 14:6-12, leading them to accept Jesus as personal saviour and to unite with His church, and nurturing them in preparation for His soon return.

\section{Our Hethod:}

We pursue this mission under the guidance of the Holy spirit through:

Preaching: Accepting Christ's commission (Matthew 28:18-20), we proclaim to all the world the message of a loving God, most fully revealed in His son's reconciling ministry and atoning death.

Recognizing the Bible to be God's infaliible revelation of His will, we present its full

message, including the second advent of Christ and the continuing authority of His Ten Commandment law with its reminder of the seventh-day sabbath.

Teaching: Acknowledging the development of mind and character is essential to God's redemptive plan, we promote the growth of a mature understanding of and relationship to God, His word, and the created universe.

Healing: Affirming the biblical emphasis on the well-being of the whole person, we make the preservation of health and healing of the sick a priority and through our ministry to the poor and oppressed, cooperate with the Creator in His compassionate work of restoration.

\section{Our Vision:}

In harmony with the great prophecies of the Scriptures, we see as the climax of God's plan the restoration of all His creation to full harmony with His perfect will and righteousness.

"Mission Statement of the SDA Church," Minutes of Spring Meeting, General Conference of the SDA Committee, Action 120-93G, April 8, 1993, 42-43. 
APPENDIX B

SDA STATEMENTS ON CARING FOR GOD'S

CREATION AND CARE FOR THE DYING 


\section{Statement III Caring for God's Creation}

VOTED, To approve Caring for Creation a Seventh-day Adventist Statement on the Environment as follows:

The world in which we live is a gift of love from the Creator God, from "him who made the heavens, the earth, the sea, and the springs of water" (Rev. 14:7, NIV; cf. Rev. 11:17, 18). Within this creation He placed humans, set intentionally in relationship with Himself, other persons, and the surrounding world. Therefore, as Seventh-day Adventists, we hold its preservation and nurture to be intimately related to our service to Him.

God set aside the seventh-day Sabbath as a memorial and perpetual reminder of His creative act and establishment of the world. In resting on that day, Seventh-day Adventists reinforce the special sense of relationship with the Creator and His creation. Sabbath observance underscores the importance of our integration with the total environment. The human decision to disobey God broke the original order of creation, resulting in a disharmony alien to His purposes. Thus our air and waters are polluted, forests and wildlife plundered, and natural resources exploited. Because we recognize humans as part of God's creation, our concern for the environment extends to personal health and lifestyle. We advocate a wholesome manner of living and reject the use of substances such as tobacco, alcohol, and other drugs that harm the body and consume earth's resources; and we promote a simple vegetarian diet.

Seventh-day Adventists are committed to respectful, cooperative relationships among all persons, recognizing our common origin and realizing our human dignity as a gift from the Creator. Since human poverty and environmental degradation are interrelated, we pledge ourselves to improve the quality of life for all people. Our goal is a sustainable development of resources while meeting human needs.

Genuine progress toward caring for our natural environment rests upon both personal and cooperative effort. We accept the challenge to work toward restoring God's overall design. Moved by faith in God, we commit ourselves to promote the healing that rises at both personal and environmental levels from integrated lives dedicated to serve God and humanity.

In this commitment we confirm our stewardship of God's creation and believe that total restoration will be complete only when God makes all things new. 


\section{Statement IV Care for the Dying}

Voted, To approve A Seventh-day Adventist Statement of consensus Care for the Dying as follows:

For people whose lives are guided by the Bible, the reality of death is acknowledged as part of the current human condition, affected by sin (Gen: 2:17; Rom 5; Heb. 9:27). There is "a time to be born, and a time to die" (Eccl. 3:2). Although eternal life is a gift that is granted to all who accept salvation through Jesus Christ, faithful Christians await the second coming of Jesus for complete realization of their immortality (John 3:36; Rom. $6: 23 ; 1$ Cor. 15:51-54). While waiting for Jesus to come again, Christians may be called upon to care for the dying and to face personally their own death.

Pain and suffering afflict every human life. Physical, mental, and emotional traumas are universal. However, human suffering has no expiatory or meritorious value. The Bible teaches that no amount or intensity of human suffering can atone for sin. The suffering of Jesus Christ alone is sufficient. Scripture calls Christians not to despair in afflictions, urging them to learn obedience (Heb 5:7, 8), patience (James $1: 2-4$ ), and endurance in tribulations (Rom. 5:3). The Bible also testifies to the overcoming power of Jesus Christ (John 16:33) and teaches that ministry to human suffering is an important Christian duty (Matt 25:3440). This was the example and teaching of Jesus (Matt. 9:35), Luke 10:3436 ), and this is His will for us (Luke 10:37). Christians look in anticipation to a new day when God will end suffering forever (Rev. 21:4).

Developments in modern medicine have added to the complexity of decisions about care for the dying. In times past, little could be done to extend human life. But the power of today's medicine to forestall death has generated difficult moral and ethical questions. What constraints does Christian faith place upon the use of such power? When should the goal of postponing the moment of death give way to the goal of alleviating pain at the end of life? Who may appropriately make these decisions? What limits, if any, should Christian love place on actions designed to end human suffering?

It has become common to discuss such questions under the heading of euthanasia. Much confusion exists with regard to this expression. The original and literal meaning of this term was "good death." Now the term is used in two significantly different ways. Often euthanasia refers to "mercy killing," or intentionally taking the life of a patient in order to avoid painful dying or in order to alleviate burdens of a patient's family or society. (This is so-called active euthanasia.) However, euthanasia is also used, inappropriately in the Seventh-day Adventists view, to refer to the withholding or withdrawal of medical interventions that artificially extend human life, thus allowing a person to die naturally. (This is so-called passive euthanasia). Seventh-day Adventists believe that allowing a patient to die by foregoing medical interventions that only prolong suffering and postpone the moment of death is morally different from actions that have as their primary intention the direct taking of a life. 
Seventh-day Adventists seek to address the ethical issues at the end of life in ways that demonstrate their faith in God as the Creator and Redeemer of life and that reveal how God's grace has empowered them for acts of neighbor love. Seventh-day Adventists affirm God's wonderful gift of redemption that provides eternal life for those who believe (John 3:15; 17:3). Thus they support the use of modern medicine to extend human life in this world. However, this power should be used in compassionate ways that reveal God's grace by minimizing suffering. Since we have God's promise of eternal life in the earth made new, Christians need not cling anxiously to the last vestiges of life on this earth. Nor is it necessary to accept or offer all possible medical treatments that merely prolong the process of dying.

Because of their commitment to care for the whole person, Seventhday Adventists are concerned about the physical, emotional, and spiritual care of the dying. To this end, they offer the following biblically based principles:

1.A person who is approaching the end of life, and is capable of understanding, deserves to know the truth about his or her condition, the treatment choices, and the possible outcomes. The truth should not be withheld, but shared with Christian love and with sensitivity to the patient's personal and cultural circumstances (Eph. 4:15).

2. God has given human beings freedom of choice and asks them to use their freedom responsibly. Seventh-day adventists believe that this freedom extends to decisions about medical care. After seeking divine guidance and considering the interests of those affected by the decision (Rom. 14:7), as well as medical advice, a person who is capable of deciding should determine whether to accept or reject life-extending medical interventions. Such persons should not be forced to submit to medical treatment that they find unacceptable.

3. God's plan is for people to be nourished within a family and a faith community. Decisions about human life are best made within the context of healthy family relationships after considering medical advice (Gen. 2:18;

Mark 10:6-9; Ex. 20:12; Eph. 5; 6). When a dying person is unable to give consent or express preferences regarding medical intervention, such decisions should be made by someone chosen by the dying person. If no one has been chosen, someone close to the dying person should make the determination. Except in extraordinary circumstances, medical or legal professionals should defer decisions about medical interventions for a dying person to those closest to that individual. Wishes or decisions of the individual are best made in writing and should be in agreement with existing legal requirements.

4. Christian love is practical and responsible (Rom. 13:8-10; 1 Cor. 13; James $1: 27 ; 2: 14-17)$. Such love does not deny faith nor obligate us to offer or to accept medical interventions whose burdens outweigh the probable benefits. For example, when medical care merely preserves bodily functions, without hope of returning a patient to mental awareness, it is futile and may, in good conscience, be withheld or withdrawn. 
Similarly, life-extending medical treatments may be omitted or stopped if they only add to the patient's suffering or needlessly prolong the process of dying. Any action taken should be in harmony with legal mandates.

5. While Christian love may lead to the withholding or withdrawing of medical interventions that only increase suffering or prolong dying, Seventh-day Adventists do not practice "mercy killing" or assist in suicide (Gen. 9:5, 6; Ex. 20:13; 23:7). They are opposed to active euthanasia, the intentional taking of the life of a suffering or dying person.

6. Christian compassion calls for the alleviation of suffering (Matt. 25:34-40- Luke 10:29-37). In caring for the dying, it is a Christian responsibility to relieve pain and suffering to the fullest extent possible, not to include active euthanasia. When it is clear that medical intervention will not cure a patient, the primary goal of care should shift to relief from suffering.

7. The biblical principle of justice prescribes that added care be given the needs of those who are defenseless and dependent (Ps. 82:3,4; Prov. 24:11, 12; Isa. 1:1-18; Micah 6:8; Luke 1:52-54). Because of their vulnerable condition, special care should be taken to ensure that dying persons are treated with respect for their dignity and without unfair discrimination. Care for the dying should be based on their spiritual and medical needs and their expressed choices rather than on perceptions of their social worthiness (James $2: 1-9$ ).

As Seventh-day Adventists seek to apply these principles, they take hope and courage from the fact that God answers the prayers of His children and is able to work miraculously for their well-being (Ps. 103:1-5; James 5:13-16). Following Jesus' example they also pray to accept the will of God in all things (Matt. 26:39). They are confident that they can call on God's power to aid them in caring for the physical and spiritual needs of suffering and dying individuals. They know that the grace of God is sufficient to enable them to endure adversity (Ps. 50:14, 15). They believe that eternal life for all who have faith in Jesus is secure in the triumph of God's love."

\footnotetext{
${ }^{1}$ Adventist Review, Dec. 31, 1992, 13-15.
} 
APPENDIX C

MAPS OF SOUTHEAST ASIA

- AND SINGAPORE 
Southeast Asia

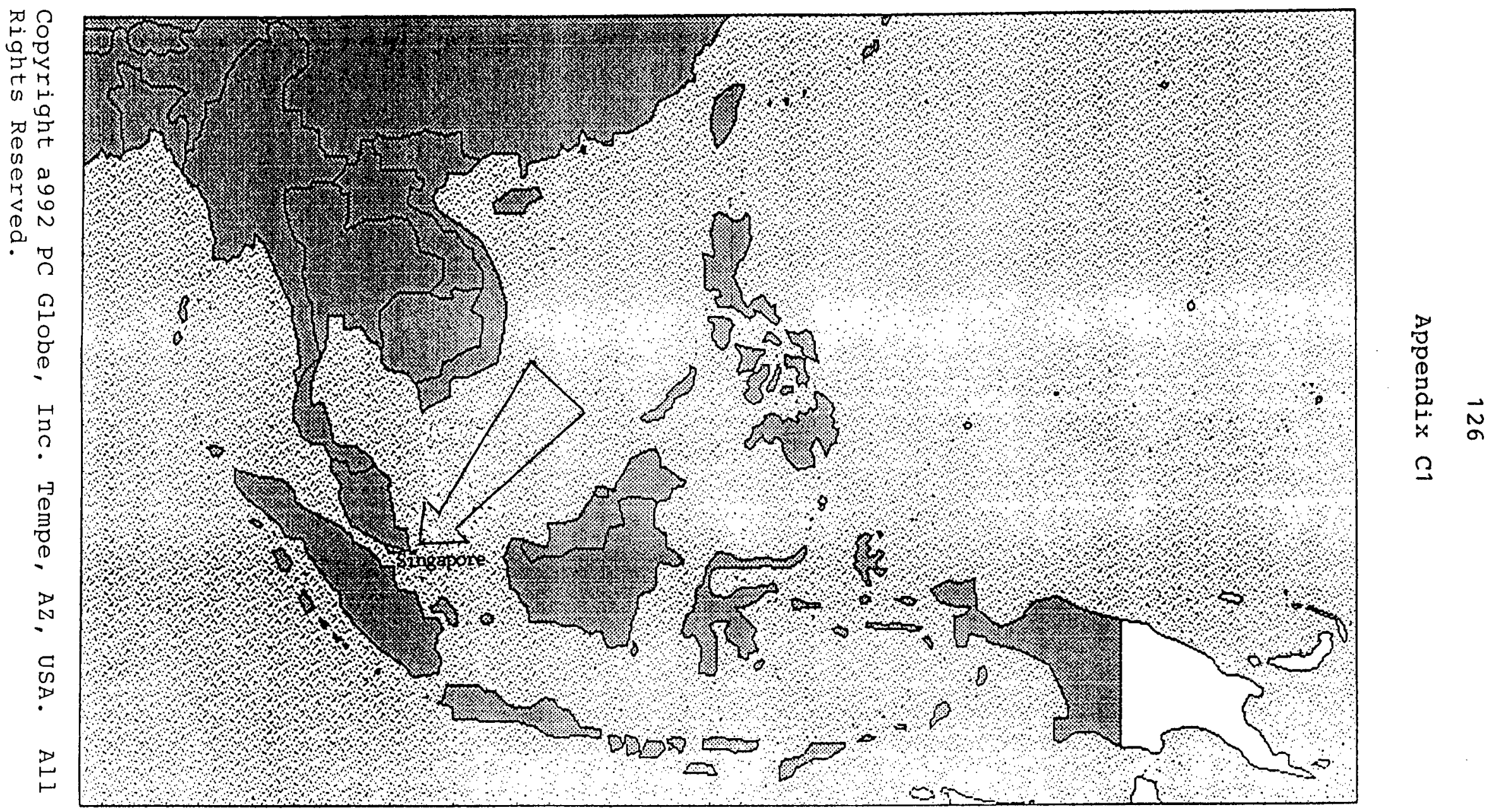




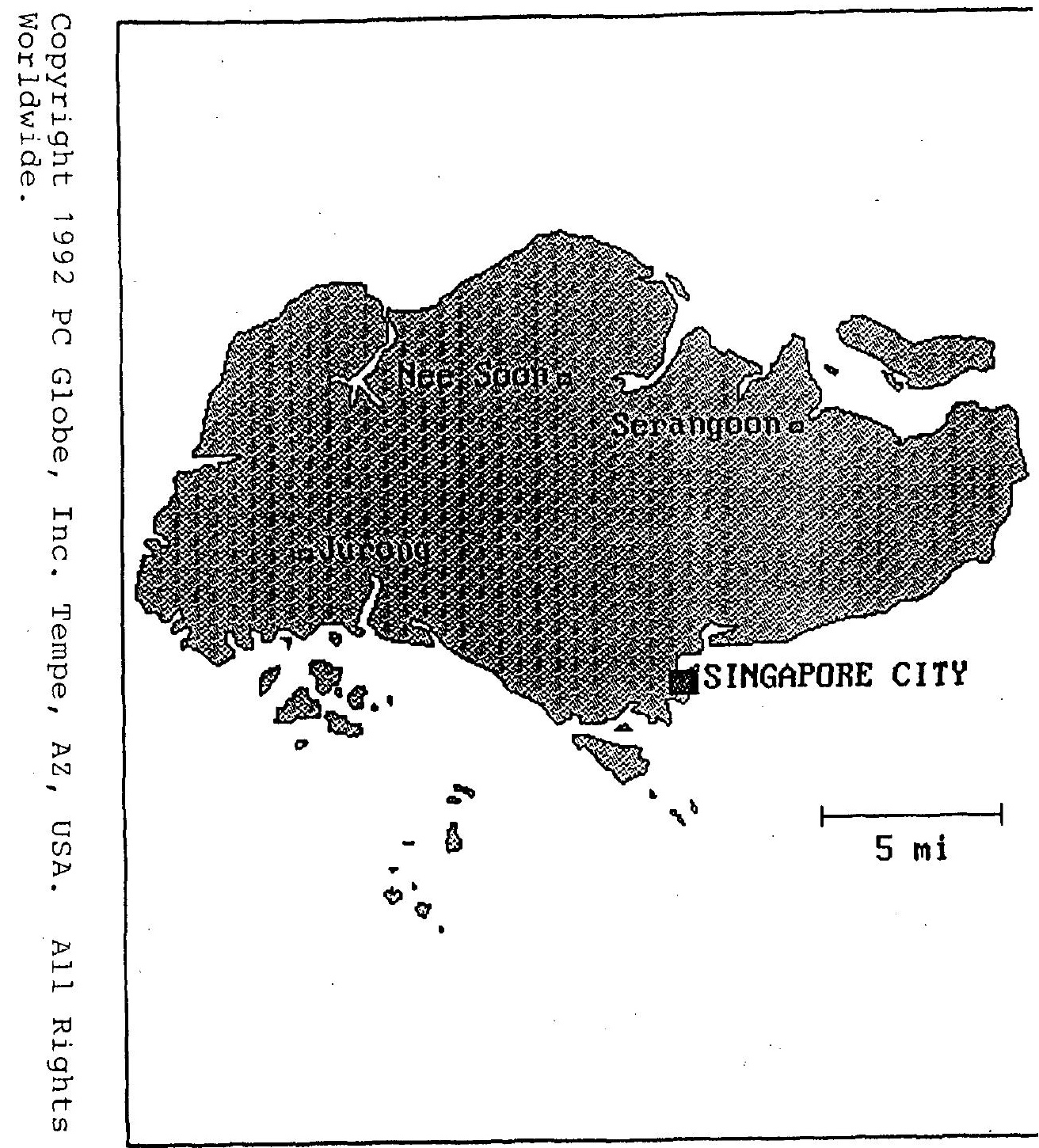




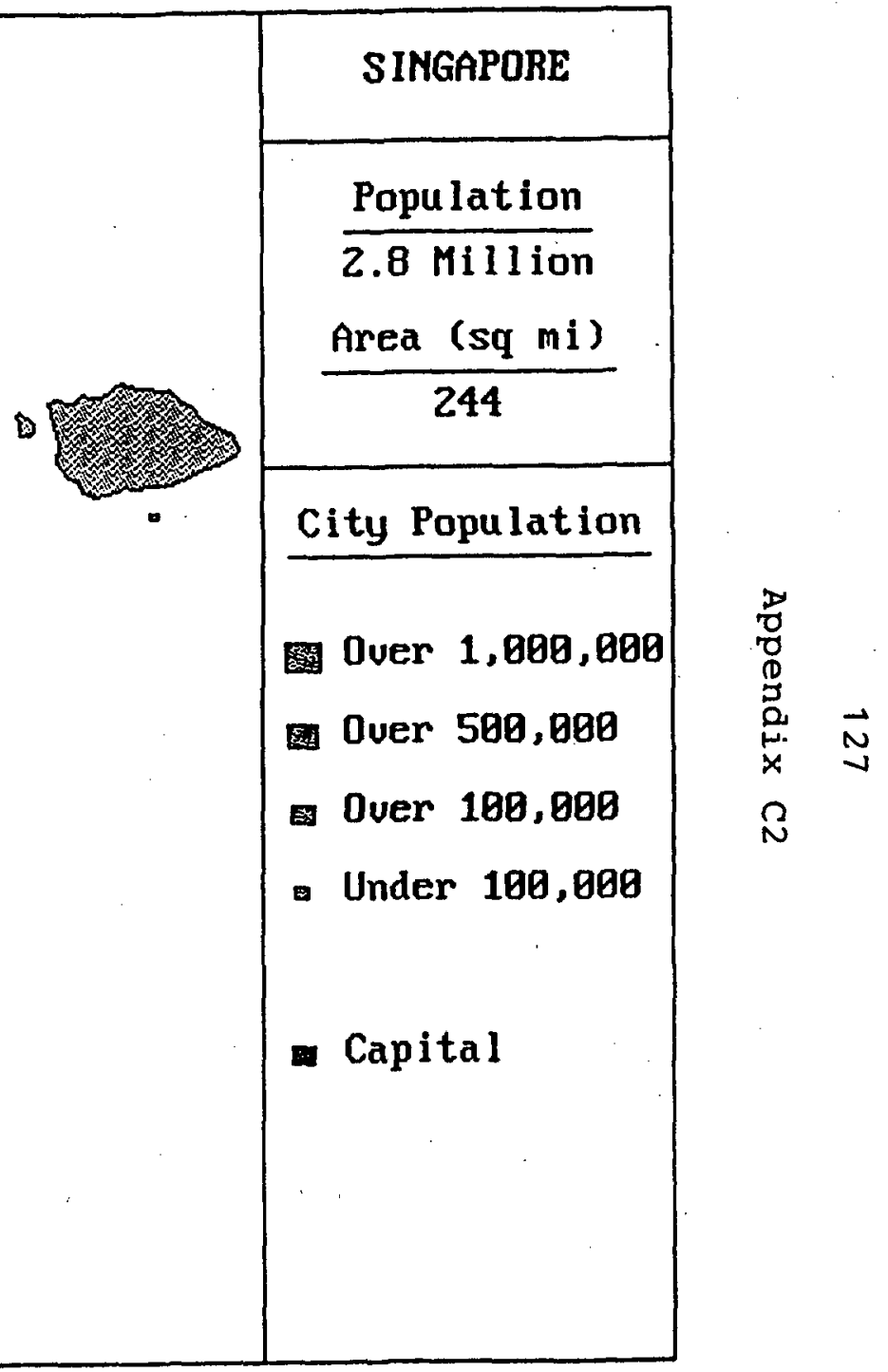


APPENDIX D

SAMPLE LETTERS FOR RETREAT 
SAMPLE LETTER (Six Months before retreat).

Date

Name

Address

Dear Colleagues in the Ministry:

Greetings! I would appreciate your help. On (date) at (location), I am offering a professional growth seminar in ministry to the grieving called the Seasons of Growth Retreat. The cost for the materials used in the retreat about $\$ 20.00$ will be paid by the SDA Mission of Singapore. However, you will have to pay for the transport and rental of the resort. The estimated cost is about $\$ 100.00$. This retreat has been developed as a result of my Doctor of Ministry project.

The objectives of the spiritual retreat are listed below:

1.Relationships: To provide further growth for pastors in relationship with God and their fellow human beings;

2.Pastoral Qualities: To further develop the pastoral qualities of genuineness, honesty, and faith;

3.Dynamics of Grief: To further understand the dynamics of grief and pastoral care;

4.Felt-need of Persons: To meet the felt-need of pastors, churches, and the community during times of bereavement.

In order to participate fully in the retreat, there are two things you can help me:

1. RSVP before (date) to the spiritual retreat.

2 . Follow the preparatory steps leading to the retreat by fulfilling the reading assignments, and filling in the Preretreat Evaluations and Inventory in My Response to Death.

Kindly inform the mission president about your availability to attend. Thank you in advance for your kind assistance in this project.

Yours sincerely,

Chor-Kiat Sim

Xc: Pastor X, President, Mr. Y, Executive Secretary and Mr. Z, Treasurer 
SAMPLE LETTER (Six Months before retreat)

Date

Name

Address

Dear Brethren/Sisters in the Ministry:

In planning for the coming pastors' retreat, I have received a letter from Pastor Sim Chor Kiat. He has completed his Doctor of Ministry degree. His doctoral project focuses on training pastors in Grief Ministry in Singapore. In order for his project to be effective, it has to be implemented in the field. The context he based his research project is Singapore. Therefore, I invite you to participate in his Seasons of Growth Spiritual Retreat.

He needs your help so that his dream of introducing Grief Recovery Ministry to Singapore can be fulfilled. The foursession Seasons of Growth Retreat will be conducted on (date) at (place). Material for the retreat will cost about $\$ 20.00$ per person and will be paid by the SDA Mission of Singapore. You will be responsible to pay for the travel and rental of the resort for about $\$ 100.00$. The Mission will provide $\$ 12.00$ per diem each day for every pastor.

There are two things you need to do before the retreat:

1. Respond to the retreat invitation so that sufficient supplies may be on hand.

2. Follow the preparatory steps leading to the retreat by fulfilling the reading assignments, and filling in the Preretreat Evaluations and Death Inventory.

Kindly inform me about your availability to attend. Thank you.

Yours sincerely,

Pastor X

President

$\mathrm{xc}:$ C. K. Sim 
SAMPLE LETTER OF CONFIRMATION(Four Weeks before Retreat) Date

Name

Address

Dear Colleagues in the Ministry:

Thanks to those who have already responded to the "Seasons of Growth" retreat. As you know, grief ministry is part of the ministry of Christ. In this age of specialization, I invite you to focus on the ministry of coping with grief. In the Beatitudes, Christ blessed those who mourn (Matt 5:34). He also showed compassion to those who grieved (Luke 8:43-56). Grief and bereavement are an inseparable part of our spiritual journey. The Lord Himself has promised the Holy Comforter to be with us even unto the end of the world (John 14:16).

I have developed a four-session spiritual grief ministry retreat utilizing the concept of four seasons. One key goal is to identify our own griefs and learn how to cope healthfully with them. There are five resources suggested for your preparation.

1. From the Bible glean 3 passages that bring encouragement, comfort, and growth to you. Please record and bring them with you.

2. Read the passage entitled, "Bereavement" in Selected Messages, Vol. II, pp. 257-274, and "Beatitudes" in Thoughts from the Mount of Blessing, pp. 9-13.

3. Read the book of your choice on the subject of grief. I suggest the books entitled, Grief Recovery by Larry Yeagley, and Grief Ministry by Reilly Williams and JoAnn Sturzl. (Grief Recovery is available at the $A B C$ and Grief Ministry has been enclosed for your reading before coming to the retreat. )

4. Prepare a one to two page life story to share with other participants at the retreat. Your story or journal may be an experience that have brought hurts or/and meaning to you.

5. Fill in the Pre-retreat Evaluation Form and the Inventory on My Response to Death. (See enclosure)

Your suggestions and inputs are welcome. May the Lord's healing power continue to be with you.

Your colleague in the Ministry.

Chor-Kiat Sim Enclosure 
APPENDIX E

LETTERS OF NIXA AND SAMUTHRAM 
133

Saint Joseph's Hospital of Marshall County

June 19, 1995

Chor-Kiat Sim

Andrews University

500 Garland Apt. G-6

Berried Springs MI 49103

Dear Sim,

I am writing to give you permission to use my story about "Cody" and the magic glasses which I read in 1993 to your CPE student group. You can use the story any way you wish if you include my name as author.

God's peace to you,

Chaplain Jeff Nixa, NACC Cert.

1915 Lake Avenue. Plymouth, Indiana 46563 • (219) 936-3181 
July 12, 1995

Pastor C. K. Sim

Andrews University

500 Garland Ave. Apt. G-6

Berrien Springs

MI 49103

Dear Brother Sim:

I give you permission to quote the experience I have at Andrews University and Clinical Pastoral Education (CPE) program at your D. Min. project. Part of it is my journey from grief to growth in my life. It has been culminated at my ordination on June 3, 1995 at Kokomo SDA Church, Indiana.

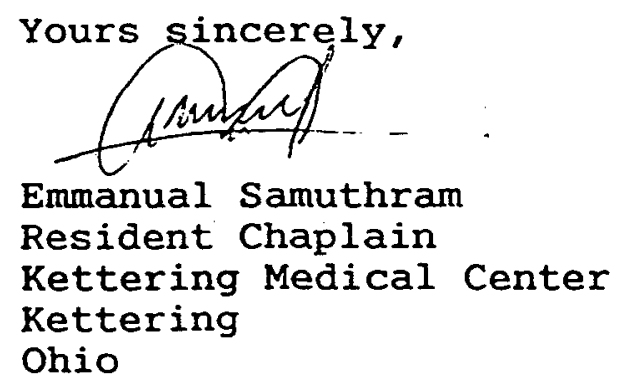

Emmanual Samuthram

Resident Chaplain

Kettering Medical Center

Kettering

Ohio 
APPENDIX F

PRE-RETREAT INVENTORY 


\section{PRE-RETREAT INVENTORY}

Objective: to assess one's understanding of grief

This questionnaire has 4 sections: I. Information, II. Grief self-assessment, III. A story based on an event of loss in your life, and IV. Inventory on My Response to Death.

Section I. Information (Circle "yes" or "no" and check " " the appropriate blank)

1. Predominantly Chinese-speaking: Yes/No

2. Bilingual skills:
A. Read and write Chinese and English: Yes/No
B. Read and write Chinese only: Yes/No
C. Read and write English only: Yes/No
D. Other(Explain)

3. Ordained:Yes/No

4. Marital Status: Married

Single Divorced

5. Number of Children:

6. Levels of education: (Check highest level completed) BA MA MDiv $\mathrm{DMin} / \mathrm{PhD}$

6. Years of paid full-time denominational service:

7. Have you completed one unit of Clinical Pastoral Education (CPE)? Yes/No 
F1 (Continued)

Section II.Self-assessment

(Scale: Strongly disagree $1 \begin{array}{llllll}1 & 3 & 4 & 5 & \text { strongly agree) }\end{array}$

A. General response of a pastor to grief:

1. I solicit support from a friend or helper during grief. 12345

2. I experience loss of trust in people during grief. 12345

3. I experience spiritual growth in period(s) of grief. $\quad 12345$

4. I feel emotionally exhausted when I am grieving. $\quad 12345$

5. I regain my enthusiasm for life at the end of grief. $\quad 12345$

6. I feel guilty when I experience loss. 12345

7. I experience a sense of helplessness when there is 1oss. $\begin{array}{lllll}1 & 2 & 34\end{array}$

8. I experience growth in faith during grief ministry. $\quad 12345$

9 I come in touch with my own grief while ministering to the grieving.

1223445

10. I try to be non-judgmental when counseling the grieving.

11. I attempt to help a mourner to have a holistic view of life.

12345

12. I believe that most people have the potential for recovery from grief.

12345 
F1 (Continued)

B.Symptoms of grief and methods in grief ministry:

1. In grieving, people experience the following:

(Scale: Poorly felt 12345 strongly felt)
a. loss of direction in life
$\begin{array}{lllll}1 & 2 & 3 & 4 & 5\end{array}$
b. mood change
$\begin{array}{lllll}1 & 2 & 3 & 4 & 5\end{array}$
c. anger
$\begin{array}{lllll}1 & 2 & 3 & 4 & 5\end{array}$
d. sadness
12345
e. self-depreciation
$\begin{array}{lllll}1 & 2 & 3 & 4 & 5\end{array}$
f. responsive to warmth
$\begin{array}{lllll}1 & 2 & 3 & 4 & 5\end{array}$
g. responsive to pleasure
$\begin{array}{lllll}1 & 2 & 3 & 4 & 5\end{array}$
h. responsive to sympathy
$\begin{array}{lllll}1 & 2 & 3 & 4 & 5\end{array}$
i. loss of control (in decision-making)
$\begin{array}{lllll}1 & 2 & 3 & 4 & 5\end{array}$

2. I used the following methods to support the grieving:

(Least used 1 . 23445 Most used)
a. prayer
$\begin{array}{lllll}1 & 2 & 3 & 4 & 5\end{array}$
b. listening
$\begin{array}{lllll}1 & 2 & 3 & 4 & 5\end{array}$
c. fine arts (e.g. music, painting, sculpturing, etc.)

d. encouragement

$\begin{array}{lllll}1 & 2 & 3 & 4 & 5\end{array}$

e. self-disclosure

$\begin{array}{llllll}1 & 2 & 3 & 4 & 5\end{array}$

f. friendship

$\begin{array}{lllll}1 & 2 & 3 & 4 & 5\end{array}$

g. appropriate touch

$\begin{array}{lllll}1 & 2 & 3 & 4 & 5\end{array}$

$\begin{array}{lllll}1 & 2 & 3 & 4 & 5\end{array}$

(Questions from 1 and 2 gleaned from schneider pp. 251-270) 
Journal Writing on Grief

Story of a significant loss in my life. Please write this story before the retreat and share it with your small group during the spiritual retreat.

(Use the back of the sheet if necessary.) Name: (Optional) 
Inventory on My Response to Death ${ }^{1}$

Circle the number that speaks for your reaction to the statement, with 5 standing for strong agreement and 1 standing for strong disagreement.

1. I hardly ever think of death $\begin{array}{lllll}1 & 2 & 3 & 4 & 5\end{array}$

2. I wish that life would not fly by so fast $\begin{array}{lllll}1 & 2 & 3 & 4 & 5\end{array}$

3. I hate the thought of looking at a dead body 122345

4. I think pre-planning funerals is ghoulish 12345

5. I am afraid of having a fatal illness $\quad 12345$

6. I change the subject when people talk about death

7. I think it is important to visit friends [members] who are very ill in the hospital $\quad 12345$

8. I worry about being in a nursing home someday $\begin{array}{lllll}1 & 2 & 3 & 4 & 5\end{array}$ 9. If the person I love most dies, I will have a hard time going on with life

Answer these questions honestly: (Answer as concisely as possible. Use the back of the sheet if necessary.)

What do I believe about heaven and hell?

What does the word 'resurrection' mean to me?

${ }^{1}$ JoAnn Sturzl and Donna Reilly Williams, Grief Ministry: Facilitator's Guide (San Jose, CA: Resource Publications Inc., 1995), 45. Original title is Death Inventory. 
APPENDIX G

THE ACRONYM G-R-O-W-T-H 
G1

(Transparency)

THE ACRONYM G-R-O-W-T-H AND THE MEANINGS IT SYMBOLIZED

G - God's Images

R -- Relationships

o -- Open-mindedness

W - - Word of God

T -- Truth of personal potential

H -- History of Persons
The Creator and Redeemer

Communication with God

Inclusiveness

Biblical Doctrines

Spiritual Gifts

Culture/Personal

Development

This acronym attempts to provide a picture of growth during grief. G-R-O-W-T-H in grief ministry centers on the following:

G--God's image: How a pastor perceives who God is has very much to do with how he/she conducts grief ministry.

R--Relationship: A pastor's relationships with God is demonstrated by how he/she relates with others.

0--Open-mindedness: A pastor's open attitude towards other gender, race or ways people grief demonstrates his/her inclusiveness in ministry.

W--Word of God: A pastor's application of the Bible in grief is vital in moments of loss.

T--Truth of personal potential: A pastor's understanding of his/her own strengths and weakness will help him/her in the way ministry is conducted.

H--Cultural and personal development: A pastor's selfunderstanding of his/her cultural background and personal development challenges him/her to continue his/her quest for learning in grief ministry. 


\section{G2}

SEASONS

\section{(transparency)}

The word, "seasons" is used to connote an extend period of time or the phenomena division of four seasons in temperate and colder zones, namely, autumn, winter, spring, summer. Chinese usually named spring first among the seasons because it signifies growth, prosperity and riches. This retreat, in order to be intervening, changes the order. It begins with the autumn and gradually brings to spring and summer, returned to where the climate singapore is throughout the year.

"Seasons" are used commonly as time and subsequently referred to the four seasons as demonstrated in these quotations:

In ordinary life the family was both a school and a church, the parents. being the instructors in secular and in religious lines. But three times a year seasons were appointed for social intercourse and worship.

The journey to Jerusalem, in the simple, patriarchal style, amidst the beauty of the springtime, the richness of midsummer, or the ripened glory of autumn, was a delight. ${ }^{1}$

Seventh-day Adventist who keeps the biblical

Sabbath should be conscious of the gift of seasons. The yearly cycle can present a picture of continuity to the weekly cycle. Other quotations referred to the appreciation of nature are cited:

God set aside the seventh-day Sabbath as a memorial and perpetual reminder of $\mathrm{His}$ creative act and establishment of the world. In resting on that day, Seventh-day Adventists reinforce the special sense of relationship with His creator and His creation.

Sabbath observance underscores the importance of our integration with the total environment. (See more on Appendix B)

\footnotetext{
${ }^{1}$ White, Education, 42 .
} 
APPENDIX $\mathrm{H}$

THE INTEGRAL COMPONENTS OF PASTORAL PERSPECTIVE 
*Appendix $\mathrm{H}$

(Transparency)

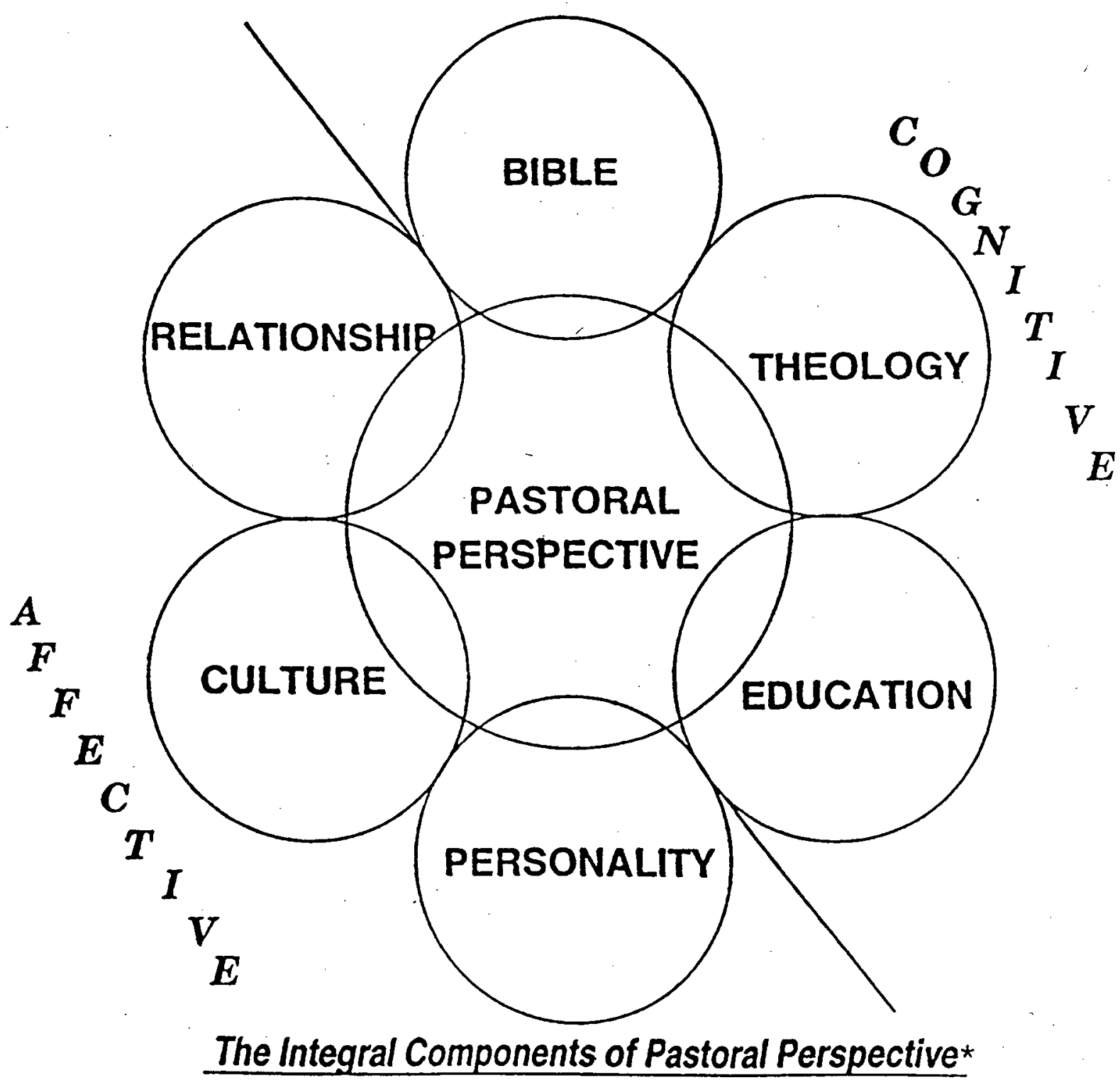

*Author's formulation based on the integral components of pastoral perspective. This pastoral perspective consists of spiritual (Bible and Theology), emotional (Personality and Education), and Social (Culture and Relationship) aspects of life that influence the way pastors conduct grief ministry. 
APPENDIX I

EIGHT STAGES OF LIFE

(Erikson) ; 
EIGHT STAGES OF LIFE

According to Erik Erickson From The LIfe Cycle Completed

(New York: W.W. Norton, 1982), pages 32-33

Stages

1. Infancy (Birth till age 2)

2. Early Childhood (Age 2-3)

3. Play Age (Age 3.5)

4. School Age (Age 6-12)

5. Adolescence (Age 12-18)

6. Young Adulthood (Age 19-35)

7. Adulthood (Age 35-65)

8. Old Age (After 65)
Psvchosocial crises

Basic Trust vs Basic Mistrust

Autonomy vs Shame \& Doubt

Initlative vs Cuilt

Industry vs inferlority

Identity vs Identity Confusion

Intimacy vs isolation

Generativity vs Stagnation

Integrity vs Despalr
Virtue

Hope

Will

Purpose

Competence

Fidellty

Love

Care

Wisdom
Radlus of Slanlficant Relations

Maternal Person

Parental Persons

Basic Family

Nelghborhood, School

Peer groups and outgroups; Models of leadershlp

Partners in frlendship, set, competition, cooperation

Divided labor and shared household

"Humanklnd," "My KInd" 
- APPENDIX J

ORDER OF EACH SESSION 


\section{Order of Each Session}

Times allotted for each session are estimates and may vary.

1. Devotion and Prayer (60 minutes)

Meeting of all the participants (Maximum 15

persons)

2. Hymns ( 15 minutes)

Meeting of all the participants

3. Story ( 45 minutes)

Meeting in small groups of 3-5

4. Exercise in small groups ( 45 minutes)

5. Reporting and recess or debriefing of all the participants (15 minutes)

6. Individual reflection and response (Participants may wish to meet with the presenter on a oneto-one basis. Individual dialogue session with the presenter can be arranged before and after the retreat to ensure quality interactions.) Topics of each activity are listed in Appendix $\mathrm{K}$. 
APPENDIX K

CONTENTS OF EACH SESSION 
CONTENTS IN EACH SESSION DURING THE RETREAT (Refer to the retreat syllabi at Appendices L1, L2, L3, and L4 for details. Materials to bring for the retreat: Bible, reading report, life story, pre-retreat evaluation, and notebook.)

\section{Autumn Session ( 3 hours)}

Purpose: To identify personal losses (particularly during childhood) and tendency to deny feeling of pain.

Devotional: The Falling of Leaves (45 min.)

Bible Text: Psa 130:1-6

Hymns: How Great Thou Art ( 8 min.)

Great Is Thy Faithfulness

Exercise 1: Self-assessment on Grief ( $45 \mathrm{~min}$.) There will be no story from the presenter for this session in order to provide time for introduction. However, each person will share his or her 5-minute life story and submit a pre-retreat evaluation as being requested by letter. (25-60 min.)

Winter Session ( 3 hours)

Purpose: To recognize the psychodynamic response to loss in a pastor's life

Devotional: The Wounds (45 min.)

Bible Text: Eccl $9: 5$

Hymns: Is My Name Written There? ( 8 min.)

Sweet Hour of Prayer

Story: An Experienced Pastor in Singapore ( 45 min.) 
Spring Session ( 3 hours)

Purpose: To identify coping mechanism with grief and to plan new strategy in grief work

Devotional: Daily Preparation for Eternity (45 min.)

Bible Texts: Matt $6: 33-34 ; \operatorname{Rev} 21: 1-4$

Story: A Chaplain's Story (45 min.)

Hymns: I Want Jesus to Walk with Me ( 8 min.) It Is Well in My Soul

Exercise 3: Holistic Transforming for Grief

Ministry

(60 min.)

Summer Session ( 3 hours)

Purpose: To continue in the grieving process by writing a new life story with holistic pastoral perspective Devotional: The Road to Emmaus ( 45 min.)

Bible Texts: Luke 24:13-33

Story: Story of My Life (30 min.)

(By the author)

Hymns: We Have This Hope ( 8 min.) Pass it on

Exercise 4: Holistic pastoral perspective revisions and post-retreat evaluation will be submitted at the end of this period. Each participant will also be sharing a re-written life story with his/her small group. (60 min.)

Debriefing Period: At this time all will be engaged in an evaluation of the retreat and in making suggestions to improve future retreat and grief ministry. (35 min.) 
- APPENDIX L

SYLLABI OF RETREAT 
Autumn Session Syllabus

Purpose: To identify personal losses and tendencies to deny feelings of pain

Introduction:

(See Chapter IV)

A. Acronym illustrated: GROWTH (see Appendix G1 and G2)

$B$. Objectives of the retreat (see Appendices $A$ and $C$ )

C. Integration of Cognitive with Affective Components

D. Reasons for the seasons

\section{Opening Remarks}

The emphasis on having Four Seasons in the spiritual retreat is based on the following: (1) to conduct a program in contrast with the non-seasonal environment of singapore to suggest change; (2) to identify with the Asian' value of time by using the term "seasons" in order to re-inculcate to them the basic necessity in life; (3). to remind participants that nature is the second book God gave; (4) to set aside time for ministerial fellowship and reflection organized in a personal and professional growth sequence. (Instead of portraying the academic "holistic pastoral perspective," the reference to "seasons" in the retreat will provide a beautiful and picturesque thematic sequence that can enhance comprehension of grief ministry cognitively and affectively. It also serves to relate with the pictorial symbols of Chinese language and culture.)

The primary purpose of conducting a seasons of Growth Retreat is to be aware of our human needs to acknowledge God as Creator, Sustainer and Re-creator. This objective will 
lead us toward a closer walk with the Creator.

What is the importance for singapore Adventists in knowing more of the truth about creation, death, and resurrection? How does this knowledge of the truth relate itself to their way of coping with death and dying? God has revealed this truth through the Bible and nature.

In the post-flood era recorded in Gen $8: 22$, God pronounced the existence of seasons, particularly winter and summer (v. 22) after He promise Noah that He will sustain the earth. This cycle of the four seasons may be a reminder of the fall and death in contrast to life and eternity.

The changes in the four seasons are visual pictures Singaporeans have missed. In challenging the participants to the retreat where relationships are emphasized, besides the Scriptures and exercises, the framework of four seasons presents the deep feelings of genuine love ${ }^{1}$ contrast with superficiality and lust the materialistic world presents. Singapore is a "concrete jungle" like any cosmopolitan city. When loss occurs, there are few retreat centers, or natural resorts where one can go to find rest and to cope with grief. Retreat centers are conducive to reflection and communion with God (Ps 46:10). An experience with God revitalizes the inner being. Therefore, to have a retreat

\footnotetext{
$1870), 3$.

${ }^{1}$ James Thomson, Seasons (NY: D. Appleton \& Company,
} 
at one of the few natural resorts or outside Singapore (e.g. Malaysia, Indonesia, or Thailand) is most helpful.

Singapore is also a small island where human interactions can be very close. The dense population in Singapore has its advantages and disadvantages. A crowded city like Singapore can be a place to nurture or destroy relationships. Living in high-rise apartment buildings in Singapore also has its disadvantages such as occasional feelings of isolation. Sometimes, the close proximity with other people may create conflicts. Therefore, a spiritual retreat, surrounded by nature, refreshes the mind, body, and soul. It goes along with Christ's invitation to His disciples to rest a while:

Come to me, all you who are weary and burdened, and I will give you rest. Take my yoke upon you and learn from me, for I am gentle and humble in heart, and you will find rest for your souls. For my yoke is easy and my burden is light (Matt $11: 28-30$ ).

To respond to God's invitation is to obey our Creator/God who is the Source of healing and life. God has made provisions for people to be healed and to experience recovery by the grace of christ.

Devotional: "The Falling Leaves"

Text: Psalm 130:1-6

The psalmist's cry to God reflects the innermost feelings of every heart, especially those who experience loss. Loss most devastating to human lives is death. 
Death is not something that we think about often. We especially try to avoid the thought of our own final passage from this life to the next. It's scary and unpredictable. Yet, every day of our lives our bodies

are aging. We rarely pay attention to this until the first real waning of energy or the first grey hairs and wrinkles or until some significant part of our body refuses to function as it should. ${ }^{2}$

Sometimes, the "dying process" with its potential for pain, incompetency, and dependency, is more fearful than death itself. Wil Alexander of Loma Linda University said,

The little death is the mere cessation of all biological human function: our heart stops beating, we stop breathing, and we are dead! The large death is a descriptive way of looking at the relentless process of our ongoing dying. ${ }^{3}$

We are not ready to let go. The dying process is more painful after experiencing "good-byes," and much more when the bereaved are left with complicated financial matters whether it is too much, or too little, to use. There are human resistances to wrestle with. Schweitzer wrote:

The main question in life is: 'How do you feel about death?' Everything that captivates us and engages us is only of relative and temporary worth. In an instant, in the very next hour, it may become utterly valueless."

The reality of our mortality can put all of life in realistic perspective. Living in Singapore, where there are

'Joyce Rupp, May I Have This Dance? (Notre Dame, IN: Ave Maria Press, 1993), 130.

${ }^{3}$ cited by Williams, Grief Ministry, $x$.

${ }^{4}$ Schweitzer, Albert. Reverence for Life (New York: Harper and Row, 1969), 67-76. 
no seasons, deprives its residents of watching nature's changes that can inspire or depress feelings. However, there are other motivators, like the occasional news of death and the fading colors of leaves and flowers.

Here are some pertinent questions to reflect on and with which claim the realities of life and death.

- Who am I? Who have I become? Who do I want to be?

- Who and what do I truly value in my life?

- What do I believe about the other side of this life?

- Will there be anything beyond this life? Will I be happy?

- Have I wasted my life? What good have I done? Was my life worthwhile? How do I want people to remember me?

- What do I need to do with the time that remains for me?

These questions cause us to go deeper, to move beyond the superficial issues of 1 ife. ${ }^{1}$ We can shift with life's transitions and prepare for them. When we let go and let God take charge of our lives, we exercise our faith and allow God's grace to lead us through.

\section{Suggestions for Reflection}

Place some dried leaves on your palms and reflect on the process of change they have undergone. Think of how

\footnotetext{
${ }^{1}$ Rupp, $131-132$
} 
life and life events change. Such an observations can help participants to gain insights about life, dying and death.

\section{Other activities:}

1. Prepare your own funeral service. Choose the readings and songs you would like to have. Do you want any special symbols to be used for your memorial service? (Can you share this planning with another person? Set a date when the large portrait for the funeral service is to be developed. $)^{1}$

2. Write your own legacy statement, concerning end of life decisions. How do you want people to remember you? What truths do you hope to have lived and shared? What has given your life a direction and satisfaction? Include these in the legacy that you hope to pass on to your loved ones.

3. What epitaph would you want on your tombstone to symbolize who you are and how you lived your life?

4. Reflect on what is ripening in your life. Make a list of your inner harvest, those parts of your deeper self that are maturing and becoming more whole. ${ }^{2}$ Set dates to write a living will with the help of a colleague.

\section{A Prayer for Autumn Days}

God of the seasons, there is a time for everything; there is a time for dying and a time for rising. We need courage to enter into the transformation process.

"Large portraits" are enlarged photographs similar to glamorous portraits, but they are used for funerals by the Chinese to remember the deceased.

${ }^{2}$ Ibid. , 138 
God of autumn, the trees are saying goodbye to their green, letting go of what has been. We, too, have our moments of surrender, with all their insecurity and risk. Help us to let go when we need to do so.

God of fallen leaves laying in colored patterns on the ground, our lives have their own patterns. As we see the patterns of our own growth, may we learn from them.

God of misty days and harvest moon nights, there is always the dimension of mystery and wonder in our lives. We always need to recognize your power-filled presence. May we gain strength from this.

God of harvest wagons and fields of ripened grain, many gifts of growth lie within the season of our surrender. We must wait for harvest in faith and hope. Grant us patience when we do not see the blessings.

God of geese going south for another season, your wisdom enables us to know what needs to be left behind and what needs to be carried into the future. We yearn for insight and vision.

God of flowers touched with frost and windows wearing white designs, may your love keep our hearts from growing cold in the empty seasons.

God of life, you believe in us, you enrich us, you entrust us with the freedom to choose life. For all this, we are grateful.

${ }^{1}$ Ibid., 139. 
EXERCISE 1: Self-assessment on Life Events

Name

Date

Below are listed events which occur in the process of living. Place a check mark in the left-hand column to each of those events that have happened to you during the last 12 months.

\section{LIFE EVENTS}

POINTS

Death of spouse

Divorce

Marital separation

Jail term

63

Death of family member

63

Personal injury or illness 53

Marriage

50

Fired from work

Marital reconciliation

Retirement

Change in family's health 44

Pregnancy

Sex difficulties

Addition to family

Business readjustment

Change in financial status 38

Death of close friend

37

Change to different job

Change in number of arguments

Mortgage/Loan over $\$ 10,000$

Foreclosure of loan

Change in Job

Child leaving home

Trouble with in-laws

Outstanding achievement

Spouse begins/stops work

Starting/finishing school 26

Change in environment 25

Revision of habits 24

Trouble with boss

23

Change in work hours 20

Change in residence 20

Change in schools 20

Change in recreational habits 19

Change in church activities 19

Change in social activities 18

Mortgage or loan under $\$ 10,000$. 17 (continued) 
(continued)

Change in sleeping habits

Change in family gatherings

Change in eating habits

Vacation

Festival holidays

Minor violations of the law

SCORE

SCORING INTERPRETATION:

If you scored:

150 or less: You have a 30 percent chance of developing an illness or change of health in the next two years.

151 - 299 : You have a 50 percent chance of developing an illness or change of health in the next two years.

$300 \&$ up : You have an 80 percent chance of developing an illness or change of health in the next two years.

According to Holmes and Rahe, ${ }^{1}$ the seriousness of

illness increases with the number of changes in your life.

So, the lower your score, the less chance you have of

becoming seriously ill. You can, of course, work to prevent illness by setting your priorities.

Some of the tensions can be reduced through relational skills introduced in $\mathrm{Ch}$. IV where relationship with God and team-work and self-understanding were recommended.

${ }^{1} \mathrm{~T}$. H. Holmes and R. H. Rahe, "The Social Requirement Rating Scale," Journal of Psychological Research II (1967), 213. There is also a Life Change Scale for Youth written by M. B. Marx, T. F. Garity, and F. R. Bowers, "The Influence of Recent Life Experience on the Health of College Freshmen," Journal of Psychosomatic Research 19 (1975): 91. 
Appendix L2

Winter Session Syllabus

Purpose: To recognize the psychodynamic response of a pastor's loss.

Introduction

Life is full of transitions that provide a variety of experiences and growth. However, transitions also bring along losses and griefs--feelings of sadness and defeat. But it is in sometimes tragic and unexpected events that people find hope and meaning in life or are crushed under loads of care. Through some of these painful lessons, principles for an enriching life have been developed, helping pastors and persons who grieve to face changes with faith, courage, and hope.

Devotional: "The Wounds"

Text: Ecclesiastes 9:5

Our memories help us to see and understand new impressions and give them a place in our richly varied life experience. Regarding memories, Henri Nouwen recalled:

I have always been fascinated by the way immigrants, especially Dutchmen respond to the U.S.A. when they come here for the first time. The first way they make themselves feel at home in their new country is to look at things which remind them of the old country. Then they start to see all the things which are larger, bigger, wider, and heavier than at home. Finally, often after several years, they begin to compare things within the country; the East with the West, the city with the countryside. When that happens then they are at home. They have built up a large enough store of memories in the U.S.A. to compare its different parts and aspects.'

\footnotetext{
${ }^{1}$ Henri J. M. Nouwen, The Living Reminder (San Francisco:
} Harper and Row Publishers, 1966), 20. 
The awareness of our memories is crucial for the way we experience life. Very often, professionals, like doctors and therapists, use these memories, that is history, to communicate ideas or to diagnose some hidden secrets. They value the memories of events.

Besides ordinary memories, the suffering we frequently encounter in the ministry, is itself a suffering of memories. These wounding memories ask for healing. Unless the suffering ones feel them, most feelings hide deeply in the center of their being and are very hard to reach. We are reminded:

While the good memories may be present to us in outer signs such as trophies, decorations, diplomas, precious stones, vases, rings, and portraits, painful memories tend to remain hidden from us in the corner of our forgetfulness. It is from this hidden place that they escape healing and cause so much harm. ${ }^{1}$

This statement means that, when we are in grief, we can suppress painful memories while we focus our minds on good memories of our exciting and joyful experiences.

\section{THE HEALING}

As to how healing of memories could take place, Nouwen said, We are healed first of all by letting them be available, by leading them out of the corner of forgetfulness and by remembering them as a part of our life stories. What is forgotten is unavailable, and what is unavailable cannot be healed. Max Scheler shows how memories liberate us from the determining power of forgotten painful events. "Remembering," he says, "is the beginning of freedom from the covert power of the remembered thing or occurrence. ${ }^{2}$

\footnotetext{
${ }^{3}$ Ibid., 22 .

${ }^{2}$ Ibid., 22 .
} 
Pastors are living reminders because their pastoral presence and liturgical images sometimes remind others of the holiness of God. Their important task is to offer the space in which the wounding memories can be reached and brought back into light without fear.

To be a reminder requires a dynamic understanding of the lives and behavior of those who need to be reminded, an understanding which offers insight into the many psychic forces by which painful memories are rejected. Anton Boisen, the father of the Movement of Clinical Pastoral Education, pleaded for this dynamic understanding when he proposed a "theology through living human documents." Many pastoral theologians and psychologists have deepened this understanding with the help and inspiration of the contemporary behavioral science. ${ }^{1}$

Since the 1960s, theological educators have become increasingly convinced of the importance of this dynamic approach to ministry, and the many Clinical Pastoral Education centers have made great contributions in this healing ministry.

Suggested questions for meditation and discussion

\section{(10 Minutes)}

A. What bitter memories have crippled my life?

B. What sweet memories have brought encouragement to me?

C. Who have been valuable "living human documents" that touched my life?

LORD'S PRAYER (Suggested)

${ }^{1}$ Ibid. , 23-24. 


\section{Story}

A SINGAPORE PASTOR'S STORY

(By C. K. Sim written on July 3, 1994)

Pastor C. P. Choong (fictitious) died at the age of 82

after 55 years of active service as a pastor and teacher for the SDA Church. His family and friends have missed a loving patriarch and friend.

Among the remarkable characteristics Pastor Choong has exemplified was the way he related to people in his dying moments. He served as an example of how a person may compose himself/herself in dying. It can be a model for Asians as well.

These are some of the messages he communicated:

1. What did dying mean to him?

Pastor C. P. Choong showed himself cheerful and friendly while being confined in the hospital. He did not show expressions of self-pity. According to Toh See Wei (one of the former pastors who is now the executive secretary of the SDA Mission of Singapore), he said that death is certain and it is the end of a full ministry. He talked about the joys in his ministry and indicated that death was the "last chapter"--the recognition of the end of his life. Death is an inevitable event that no one can avert, but there is nothing to fear. He recalled his experience of God's protection through the tragedy of war 
during the Japanese Occupation. He said he was summoned to interrogation twice. Normally, those summoned for the second time did not return alive. Those memories strengthened his faith in God, even in his dying moments.

2. In what ways did his Christian life contribute to his ability to accept death?

He had a rewarding Christian experience. He led a well-adjusted Christian life based on the standards he learned. A lasting rule he advocated was to practice the Golden Rule. Choong said that life should be lived to the fullest. In his life-time, he spoke with humor about people who squandered away their time by having "Tidak-apa" or careless attitude.

On the other hand, he admitted his weakness. On one occasion he resigned from his service as a principal in Sabah. This indicated that he accepted his limitations as a mortal being. Relatives and friends learned positive ways to accept death as an inevitable event in one's life.

3. How did he want to be treated after his death?

He let go and prayed that the succeeding generation would love the Lord. He gave his caregivers in his dying days explicit instructions ranging from what to give out during his funeral service to who would participate in his memorial services. He suggested to his pastor the topic of his sermon. He instructed his caregivers to give out white 
napkins during the funeral service as a symbol of surrender, a symbol of giving up, and a message of righteousness, meaning Christ had cleansed all from their sins. Toh See Wei said that he was very precise:

He discussed with a staff his funeral procedures in details. He identified a few younger ministers to take part, implying his wish that his ministry of love continue. He told a young minister that, though his chapters in ministry had come to an end, he encouraged the young minister to treat his ministry as a fresh beginning. He talked about practical things such as communication skills like having a close relationship with the treasurer.

4. What was the impact of his life on other people after his death?

His funeral services were well-attended. His students who read about his death grieved over their loss. People who had association with him learned from the life experiences he shared. He cherished the lessons he learned in his ministry. His wife, son, and daughter mourned over his death. His contributions to the church after his retirement had been remarkable. He had been regular in his attendance and provided the church with seasoned counsels regarding church- management issues.

Pastor C. P. Choong had the ability to compose himself in dying and had prepared himself for his death because he had integrated grace with the law; and theory with practice.

Hymns: Is My Name Written There

Sweet Hour of Prayer 
Exercise 2: Plans for Grief Ministry

Each pastor prepares a grief ministry plan for

his/her church with consideration of time: past, present and future. $^{1}$ (Whereas the Image of God is central to the theological framework of this project, the plan for grief ministry is focusing on Christ, the same yesterday, today and forever (Heb 13:8). The spiritual Issues focus on a pastoral visits, preferably with reference to the pastor himself/herself:

Past

-Connected to past

-Reviving past support

-Expressing feelings about the past

-Seeking forgiveness

Present

-Search for meaning

-Express feelings

-Make decisions about death

Future

-Find ways to leave a legacy and be remembered

-Move to sense of completion and letting go

Religious Resources

Past

-Rituals of reconciliation

-Prayer/Scripture/devotions

${ }^{1}$ Donna Reilly Williams and JoAnn Sturzl, 95. 
Present

-Sacraments/rituals/symbols

-Presence of faith community

-Prayer/Scripture/devotions

Future

-Hope in God's promise of resurrection life

-Hope in continuity of life through descendants

In connection with the suggestions above, pastors may plan a series of sermons and seminars on Grief Ministry.

(See work-sheet for the last session of the retreat in

Appendix N.)

Summary of Personal Grief Ministry Objectives

Write a summary of your objectives for a project in

Grief Ministry:

A professional objective:

Examples:

1. I will preach a sermon on grief when someone or someone related to a member dies.

2. I will visit a family in the community who losses a loved one each quarter.

A personal objective:

Examples:

1. I will read a book on grief and report its summary to a ministerial fellowship each year.

2. I will conduct a grief recovery seminary

before my evangelistic crusade each year and invited

participants to the crusades if possible.

Name:

Date: 
Appendix L3

Spring Session Syllabus

Purpose: To identify a pastor's current coping mechanism and to plan new strategies for grief work.

Introduction

Spring provides the environments with fragrance from the blossoming plants. Similarly, the fragrance of giving is found in Chinese traditions and communities. Singapore Chinese have demonstrated such a spirit as seen in their generous giving to memorial projects. Some of these projects are institutions, parks, and buildings named after their founder, donor, institution or place. Hong Lim Park, Tan Tock Seng Hospital, Youngberg Hospital, Raffles Hotel, Shaw House, Chen Lin College, Ngee Ann College, and the National University of Singapore (part of it was the former Nanyang University) were established by individual philanthropists.

Many of the SDA Church members in Singapore are generous. Generousity in giving time and talents is essential to provide support in grief ministry: helping people in grief to cope with losses.

Devotional: "Daily Preparation for Eternity" Text: Matthew 6: 33-34 
"Seek first God's kingdom and [God's] righteousness, and all these things will be given to you as well.

Therefore do not worry about tomorrow, for tomorrow will worry about itself. Each day has enough of its own."

If we have given ourselves to God, to do God's work, we

have no need to be anxious for tomorrow. God knows the end from the beginning. The events of tomorrow that are hidden

from our view are open to the eyes of our omniscient God. White encouraged us by saying,

When we take into our hands the management of things with which we have to do, and depend upon our own wisdom for success, we are taking a burden which God has not given us, and are trying to bear it without God's aid. We are taking upon ourselves the responsibility that belongs to God, and thus are really putting ourselves in God's place. We may well have anxiety and anticipate danger and loss, for it is certain to befall us. But when we really believe that God loves us and means to do us good we shall cease to worry about the future.'

Christ has promised us help, as we bear our burdens daily ( 2 Cor 12:9). God's grace is bestowed upon us daily. Jeremiah and Isaiah testified about the blessed life and trust in God (Jer 29:11; Isa 30:35). Also, White has counseled,

If you will seek the Lord and be converted everyday; if you will of your own spiritual choice be free and joyous in God; if with gladsome consent of heart to God's gracious call you come wearing the yoke of Christ,--the yoke of obedience and service,--all your murmuring will be stilled, all your difficulties will be removed, all the perplexing problems that now confront you will besolved. ${ }^{2}$

For everyday growth, the hope of eternal life and of the heavenly home encourage us (Rev 21:1-4).

\footnotetext{
${ }^{1}$ White, Thoughts from the Mount of Blessing, 100.

${ }^{2}$ Ibid. , 101
} 
Let us pray together. (FOR THE COMING OF SPRING)

We give Thee thanks for the loveliness of spring with its promise of summer.

Bird and blossom seem to tell us of the possibility of new life for our own souls. This spring day speaks to us of beginning again, of new beauty that can come to refurnish our own barren lives.

o Lord Jesus, may that transformation begin in us now as we sit before Thee--penitent and expectant. Amen.'

\section{Story (Allegory)}

A Chaplain's Allegorical Story

(Chaplain Jeff Nixa told C. K. Sim this story in January 1993--See appendix P)

Some years ago, there was a CPE student chaplain who worked in a large hospital. The Chaplain worked hard and listened fairly well to patients. She had years of ministry experience in churches, schools and missions. But lately, the CPE student had been told by her peers in interpersonal group meetings (IPG) that, in her verbatims, she wasn't hitting the most important issues with patients; and, at times as a consequence, the impact of her ministry was short-lived and a bit shallow. She was very frustrated and developed a persistent pain in her neck and shoulder.

One day, while the chaplain was waiting for a meeting with her CPE supervisor, she met a few hospital staff. One of them was a house-keeper who handed her an odd pair of mirror sunglasses. She put them on her and left. Things looked different with those mirrored glasses on. Each staff carried a big load. Being perplexed and frustrated, she went into the restroom to splash some cold water on her face. When she looked in her mirror with the glasses on, she was surprised to see, instead of her normal face, a mask with a big smile on it. Over her shoulder, she saw that she was carrying a huge shoulder bag with a big cross embroidered on it, filled with Bibles, prayer books, songs, guitar, a

${ }^{1}$ Catherine Marshall, ed. "For the Coming of Spring", The Prayer of Peter Marshall (NY: McGraw - Hill Book Company, Inc., 1954), 74. 
church organ, some band-aids and a small congregation of angry people. She recognized them from the small church that she had left years ago, shouting her name. "O dear," she said.

She took off the smiling face mask and was frightened to see the tired face of a person carrying a heavy load. Immediately, she quickly removed the mirrored glasses and was relieved to see the smiling face returned. The huge shoulder bag was gone; but, somehow, she could still feel the weight.

The chaplain only had one more visit to make that day, so she went to the pediatric unit hoping to cheer up some children. As she passed the waiting room, she noticed a young boy in pajamas, seated alone and staring at an aquarium.

"Hi, I'm the chaplain. Who are you?"

"Cody," was the reply, then he added, "Why do you have those funny glasses on?"

"Well, they help me see you better," the chaplain replied.

"Can I try them on?" Cody insisted.

Before the chaplain could refuse, Cody had them in his hands and tried them on.

"Oh, I see what you mean!" he said.

"Nice mask. But boy, the weight of that bag might hurt your shoulder!" Cody thought.

"Why, yes, it does," said the chaplain, embarrassed.

"Why don't you take it off?" Cody inquired.

"Why I need to be a good chaplain!"

"Why? What do chaplains do?"

"Well, we go around and try to understand people and, oh well, it's very complicated." The chaplain explained.

"I still don't see how the stuff in the bag helps." Cody wondered.

"You're young," the chaplain reasoned out. 
"And confused," cody quickly added.

"Why?" the chaplain inquired.

"Well, because you're smiling but you're not smiling. It's confusing me." Cody quickly answered.

"What do you mean?" the chaplain inquired.

"Your mask. It's smiling, but your real face isn't." Cody retorted.

"Chaplains need to smile. Now, why are you in the hospital?" the chaplain inquired.

"I've got cancer," the boy replied.

"You do?" The chaplain insistently asked.

"Hey, you dropped your smiling mask," Cody suggested.

"I'm sorry. I'll put it back on," the chaplain reacted.

"No, don't be sorry. Everyone is smiling at me all, the time when I feel sad, like you are right now," Cody explained.

"What do you mean?" the chaplain asked.

"You know, your real face is sad right now. That's exactly how I feel! Finally, someone understands!" Cody interpreted.

"Oh. Well, uh, would you like a prayer?" the chaplain asked.

"Nope." Cody smartly answered.

"How about a nice song?" the chaplain insisted.

"Nope." Cody retorted again.

"A nice Bible story?" the chaplain insisted again.

"No, no, my mom reads me stories all the time," Cody explained.

"Well, I'm not sure how I can help you, Cody!" the Chaplain wondered.

"Yes. You can!" Cody answered. 
"How?"

"I'11 tell you about my cancer, and you'll understand!" Cody explained.

"But I don't have cancer!" the chaplain retorted.

"It doesn't matter because I can see that you know about sad things and pain from all the stuff in your bag." Cody further explained.

"Oh, I don't want to burden you with..." the chaplain insisted.

"Just be quiet and listen to me, Okay, Jesus?" Cody interposed.

"Jesus?" murmured the chaplain in awe.

The chaplain sat stunned and just then, the housekeeper came around the corner with her jacket and gloves on.

"Well, chaplain, how are those mirrored glasses working?" the housekeeper asked.

The chaplain wasn't sure what to say. This was not what she had expected.

"They work great!" said Cody.

"Good. See you tomorrow," said the housekeeper with a wink to Cody, and she disappeared around the corner.

Hymns: It is Well with My Soul

I. Want Jesus to Walk with Me

Exercise 3: Holistic Transformation in Dimensions of Grief ${ }^{1}$

Each pastor identifies a grief experience (either personal or non-personal) in his/her ministry and give a report by answering the following questions in a report or

${ }^{1}$ Schneider, 236 . 
verbatim form:

1. What has happened during the time of loss? This is the cognitive aspect which focuses on context, and personal involvement.

2. How does it feel? This is the emotional aspects that have to do with how anger, disgust, sadness, or guilt are felt.

3. What spiritual dynamics take place? This is the spiritual aspect of grief that has to do with letting go, forgiveness, etc.

4. How do the persons involved conduct themselves. This is the behavioral aspects such as saying good-bye, finishing business, sharing responsibilities, acts of forgiveness, making restitution, etc.

5. How to cope with grief and maintain health? This is the physical aspect that has to do with detachment, and self-care.

The above questions based on the various components of the holistic pastoral perspective. (See Appendix $\mathrm{H}$ ) Ultimately, they provide pointers for pastors to understand their roles and responses to losses in their ministry. 
Appendix L4

Summer Session syllabus

Purpose: To continue in the grieving process by writing a new life story with holistic pastoral perspective

\section{Introduction}

Summer time reminds us of creation and creation reminds us of the beautiful surroundings God gave us. In spite of the Fall of humankind, flowers still bloom and rain still falls. Animals decorate landscapes and the atmosphere. Dew drops shine with multi-colored splendor. Night comes to provide solace and rest. Days are for work and fun.

\section{Devotional: Hearts on Fire}

Text: Jeremiah 20:9

I like a campfire. It makes me contemplative. I love to watch the flames dance on the logs and light up the night. They brighten my life. Fire gives me warmth and keeps my desire for life burning while light is the result of this burning passions. Light shines and helps me to see the present and future while fire keeps my desire for life ardent.

Jeremiah uses fire to describe the presence of God within him. One writer described such an experience:

Jeremiah did not welcome this flame of God within him. It seemed too much for him. He fought its being there and even accused God of seducing him. In spite of his loud protestations, Jeremiah did act on the dynamic burning in his heart. He surrendered to the flame for truth and justice. His voice blazed with God's word.

\footnotetext{
${ }^{1}$ Rupp, $106-107$
} 
In the presence of God, feeling His power, we sometimes respond with resistance. Resistance tends to shield me from acknowledging God's presence and brings darkness in my life. But God is the true Light (Matt 5:1316; John 5:35).

I invite you to walk in the Light as a result of your burning desire to live for God. By looking at the Light, we may be drawn along the path of righteousness. Therefore, our challenge is to put self aside, and to trust in the Light.

Throughout the Bible, fire is also used to symbolize the divine presence. A remarkable experience about the disciples who felt the burning with the Holy spirit as recorded in Acts 2: 42-47. Some other examples are:

Moses approaches the fire of the burning bush and hears the frightening call to lead the people out of their slavery into freedom (Ex 3:2). Before Isaiah can go forth to share God's message his mouth is purified by red hot coals that are carried by seraphs ("burning ones") (Is 6:1-13). The Exodus travelers knew the pillar of fire at night as a comforting and reassuring sign of God's guidance and protection as they sought a place of freedom (Ex 13:21-22). Peter writes that the fire of God is a source of purification, something that refines our faith ( 1 Pt $1: 6-9$ ). The fearful and trembling followers of Jesus received the fire of courage and inner conviction when tongues of fire came over their heads in the Upper Room (Acts 2:1-13). And the author of the letter to the Hebrews refers to God as "a consuming fire" (Heb 12:29)."

As we reflect on these passages, we see ourselves better with our hearts burning with desire for God. We would also be able to see God and His characteristics better. We see how patient God is in bestowing His gifts

\footnotetext{
${ }^{1}$ Ibid., 108
} 
upon us. By keeping close to God, we feel the spiritual fire burning within and see the Light of life shine before us to illumine our paths. We find courage, experience change, and feel revived. In God's love, we experience the reality of God's deliverance. Full redemption will be realized at Jesus' Second Advent.

Closing Prayer

God of passionate life, who sends the sparks, who lights the inner blaze and tends the flame, fill us with your radiance. Enkindle us with your love. Touch us with your goodness so that we will be the kindling of your generous compassion. May the truth we seek and accept shine through all we are and do. God of passionate life, stir up the embers of our joy. Amen.'

Story

(My Pilgrimage)

I was born in a farming village near Swatow (a harbor town) in southern China on Nov. 26, 1947. My upbringing was that of traditional Chinese. The Chinese view faith and work as complementary to each other. This is an example of Yin and Yang. I had also been taught to reflect because I was the only child and had much time for myself. When I was ten years old, the study of geography inspired me. There was no Bible or church in my home-town. Nature, then, was the guidebook which brought me to believe that there must be a Creator. My young mind used to think: How did the world come about? After much thinking, I concluded that there must be a God who created it.

\footnotetext{
${ }^{1}$ Ibid. , 115 .
} 
Providentially, I left China in 1958 for Singapore where there are Bibles and churches. I was also enrolled in a Seventh-day Adventist School by my granduncle. The study of divine truth in a Christian school led me to feel God's presence and to grow personally. I had been guided by God to believe more firmly in creation in my life:

First, when I read the Bible and the book, steps to Christ, they inspired me to believe that God loves me. I decided to become a Seventh-day Adventist Christian. I was convicted that I had found the truth. My dedicated teachers taught me the truth.

Further, in my adulthood, I received more truth about God through the Bible and nature. The natural surroundings provided me directions to make decisions. It seems that God spoke to me through nature each time. I felt that it was God who led me to be a pastor. I have served God as a pastor since 1969. From 1987-1991, I worked as pastor and administrator. In these four years, I learned, but there were pages in my life's history to painful to write. (I will share with you during the retreat by request.)

In August 1991, I arrived at Andrews University after 21 years of pastoral work. Leaving the congregation of my last church and presidency in singapore were difficult. I felt much loss in this transition. However, winter was beautiful. The barren trees, with their potential to sprout leaves in spring, seemed to assure me of my growth and recovery. 
I believe in my Creator who teaches me to love and to care. Through His creative power, I was able to continue my study of Creation and Pastoral Care. My trust in God has increased. The study of Creation is not an option for pastors. It is an imperative. Constantly, God's recreative energy is acting in me. Without such power, I would not have been able to minister to my parishioners and patients. Through such recreative power, I am able to care, to heal, and to grow. I also gained courage to live according to 2 Tim. 1:7. I am continuing to develop my pastoral perspective through reflections in my living and my ministry. The power of God is always available for all pastors and believers. Continuing education is "the work of a life-time; and when this life ends, the same work will be carried forward in the future life". ${ }^{1}$ There is a promise about the creative power from the creator:

If a person is thirsty, let him/her come to me and drink. Whoever believes in me, as the Scripture has said, streams of living water will flow from within him/her" (John 7:37-38).

Hymns: We Have This Hope

Pass It on

${ }^{1}$ Ellen G. White, "Diligence, a Necessary Qualification in the Minister" Advent Review and Sabbath Herald (Battle Creek, MI: Advent Review and Sabbath Herald, 1886), paragraph 14. 
Exercise 4:

Section I. POST RETREAT EVALUATION (To be submitted after the retreat)

Evaluation of GROWTH Spiritual Retreat for the Presenter Scale: Very Unsatisfactory $1 \begin{array}{llllll}1 & 2 & 4 & 5 & \text { Very Satisfactory }\end{array}$ 1. The presenter has reflected thorough grasp of the subject of grief ministry. $\begin{array}{lllll}1 & 2 & 3 & 4 & 5\end{array}$

2. I have been encouraged to review my image/concept of God as a theological framework for pastoral ministry. 12345 3. I have been encouraged to commit myself faithfully to grief ministry.

$\begin{array}{lllll}1 & 2 & 3 & 4 & 5\end{array}$

4. The retreat had a clear spiritual emphasis. $\quad \begin{array}{rllll}1 & 2 & 34 & 4\end{array}$ 5. I know my roles better as a pastor/healer in grief ministry

6. I have a clearer perception of the cognitive (theological, biblical and educational) concepts in grief ministry $\begin{array}{lllll}1 & 2 & 3 & 4 & 5\end{array}$ 7. I have a clearer perception of the affective (personal, cultural, and relational) concepts in ministry 
Section II.

A. GRIEF MINISTRY PLANS: I plan to engage in increase grief ministry by the following methods:

preaching

teaching

pastoral visits

prayers

other pastoral functions such as

B. Set objectives on each of the above:

Preaching: (Example: I will preach a sermon on grief once every three months.)

Teaching: (Example: I will conduct a Grief Recovery Seminar.)

Pastoral visits:

Prayer:

Others pastoral functions:

Name (Optional):

Date: 
APPENDIX M

OBJECTIVE IN INVENTORIES, QUESTIONNAIRES AND STORY-TELLING 
Objectives of Inventories, Questionnaires, and Story-writing

This research uses inventiories, questionnaires and story-writing as its means of measuring the qualities of pastors' perceptions or methods in the ministry. The Inventory on My Response to Death, pre-retreat questionnaires, and request for a story are sent to participants of retreat three weeks before the first meeting which has been identified as the Autumn Session.

\section{Inventory on My Response to Death}

Objective: This instrument serves to confront participants with the stark reality of death. Its questions about perception of heaven or hell and resurrection explore their theological beliefs which determines the way grief ministry is conducted.

2. Pre-retreat questionnaire on pastoral responses to grief.

Objective: These instruments attempt to explore pastors' response and sensitivity to grief. They are given before and after the retreat proposes to assess whether they have made progress or digressed during the training.

3. Pre-retreat questionnaires and post-retreat inventory based on pastoral methods practiced in grief ministry.

Objective: These instruments explore the methods and styles pastors used in ministering to the grieving persons. The questionnaires before the retreat proposes to assess what have been used and evaluation after the retreat help to see which available methods may be used.

4. Story of a grief event before the retreat facilitates participants to relate with loss personally.

Objective: The story of a person's grief event enables one to review his/her loss. Sometimes, some hidden hurts may be unraveled to facilitate healing--unless wounded memories are uncovered, they remain sources of hurts. Story-telling is intended to facilitate persons to heal and gain perspective. It "is a restructuring of our perception of what we have been in order to gain a clearer picture of what we are becoming." 1 When an opportunity is given to write or to tell stories, most persons will think, reflect, and work on their grief.

${ }^{1}$ David A. Steere, ed. The Supervision of Pastoral Care, 125. 
Statistical Methods Illustrated

The statistical methods are adapted from "Demographic, perceptual, and religious determinants of pastoral counseling" from Handbook for Doctor of Ministry Project, (NY: University Press of America, 1986), 54, 201-205.

There are three main sections of evaluation: the "demographic, perceptual and religious determinants

1. Demographic determinants are based on cultural background (determined by the use of languages), ordination status, and CPE training.

2. Perceptual determinants are similar to selfassessment based on general response. (Other determinants in the section are symptoms and pastoral methods in grief ministry) .

3. Religious determinants are paralleled to theological framework integrated to an event of grief in a pastor's life story.

In this study, these determinants as adapted according to the following hypotheses:

HYPOTHESIS

A. The more bi-lingual (English and Chinese) a pastor is, the less traditional and detached he/she is from the Chinese roots.

B. The more the pastor is endorsed by ordination or commission, the more he/she is able to be sensitive to those who suffered loss.

C. The more CPE trained the pastor is, the more aware he/she is of self and effectiveness in ministry. 
TABLE FOR RESPONDENTS ARE PRINTED BELOW

(Abbreviations: Standard deviation $=S D$, Normative $=N$ )

Hypothesis A

Groups

Mono-lingual

Bi-lingual

$(N=\quad)$

$(\mathrm{N}=\quad)$

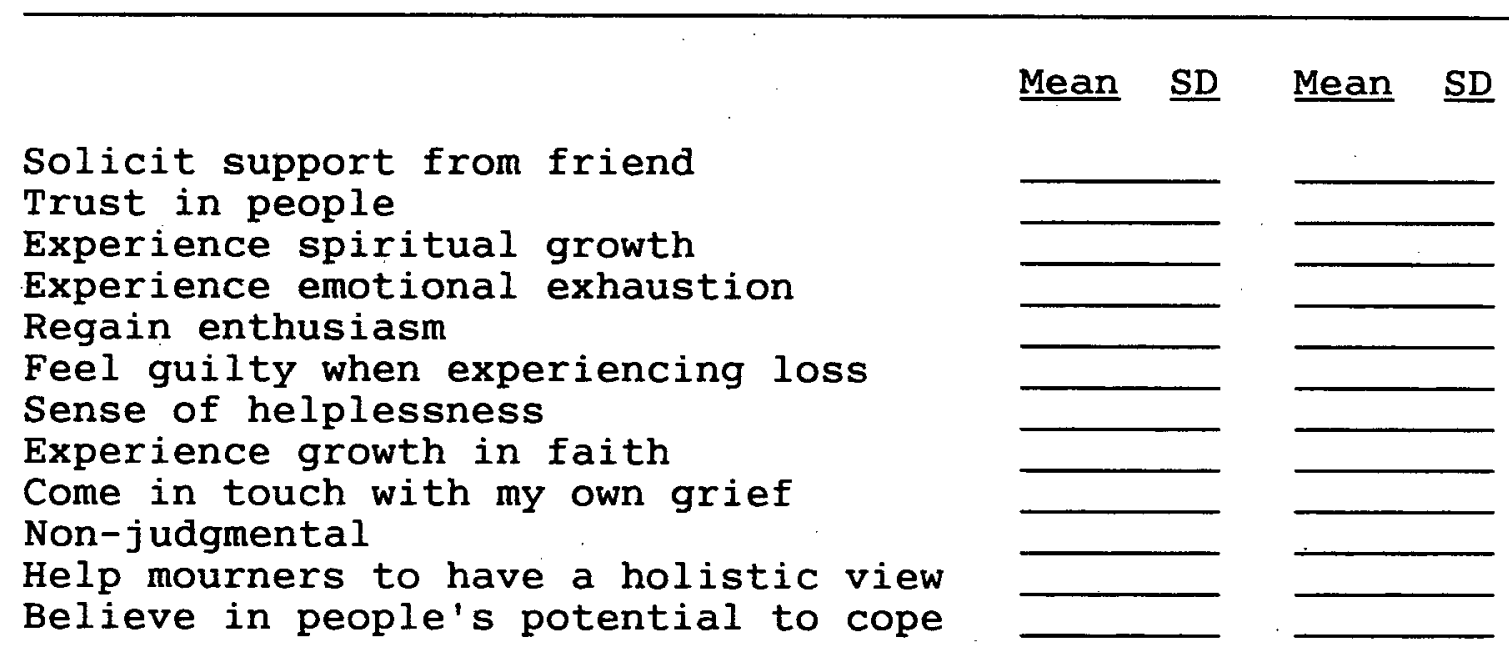

Findings from statistics:

$\begin{array}{lll}\text { Hypothesis B } & \begin{array}{l}\text { Ordained } \\ (\mathrm{N}=)\end{array} & \text { Groups } \\ (\mathrm{N}=)\end{array}$

Mean SD Mean $\underline{\text { SD }}$

Solicit support from friend

Trust in people

Experience spiritual growth

Experience emotional exhaustion

Regain enthusiasm

Feel guilty when experiencing loss

Sense of helplessness

Experience growth in faith

Come in touch with my own grief

Non-judgmental

Help mourners to have a holistic view Believe in people's potential to cope

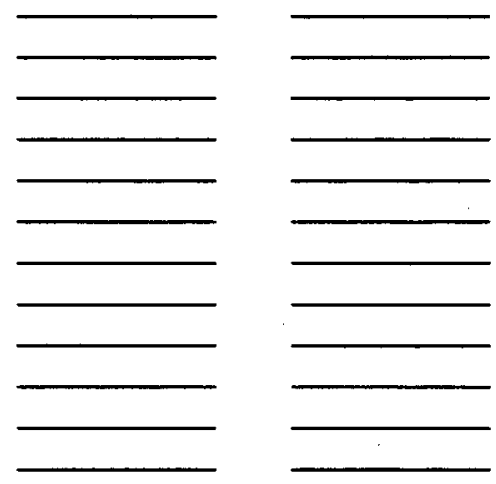

Findings from statistics: 
Hypothesis C

\section{Groups}

CPE Trained

$(\mathrm{N}=\quad)$
$(\mathrm{N}=\stackrel{\text { Non }}{)}-\mathrm{CPE}$

Mean SD Mean $\underline{\text { SD }}$

Solicit support from friend Trust in people

Experience spiritual growth

Experience emotional exhaustion

Regain enthusiasm

Feel guilty when experiencing loss

Sense of helplessness

Experience growth in faith

Come in touch with my own grief

Non-judgmental

Help mourners to have a holistic view

Believe in people's potential to cope

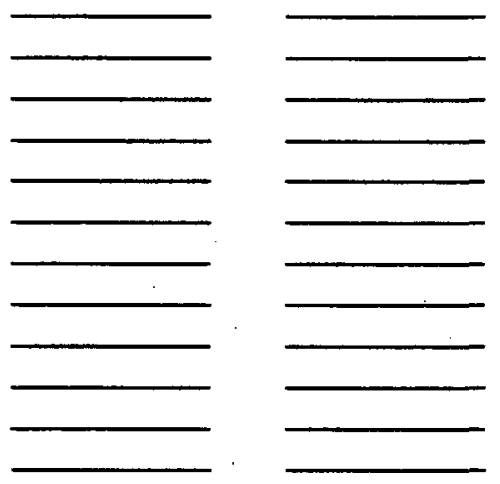

Findings from statistics:

Three more sample basic questions based on

Hypothesis A:

Are mono-bilingual pastors more ready to seek help than the

bi-lingual pastors who rely more on self?

Hypothesis B:

Do ordained pastors who have more experience able to minister to the grieving with more initiatives?

Hypothesis C:

Are pastors with CPE training able to minister to grief in order to reach out to their colleagues for support?

Conclusion:

Conclusions of these surveys and recommendations will depend on the responses of the respondents when the research is conducted. 
BIBLIOGRAPHY 


\section{BIBLIOGRAPHY}

Aden, Leroy, ed. Christian Perspectives on Human Development. Grand Rapids, MI: Baker Book House, 1992.

Augsburger, David W. Pastoral Counseling Across Cultures. Philadelphia: Westminster Press, 1986.

Bacchiocchi, Samuele. Divine Rest for Human Restlessness. Berrien Springs, MI: By the author, 1980.

Bailey, Lloyd R. Biblical Perspective on Death.

Philadelphia: Fortress Press, 1979.

Barry, William A., and William J. Connolly. The Practice of Spiritual Direction. New York: Seabury Press, 1983.

Berkhof, Louis. Systematic Theology. Grand Rapids, MI: Wm. B. Eerdmans Publishing Co. 1976.

Boisen, Anton T. Out of the Depths. New York: Harper Press, 1960 .

Bowers, Margaretta K. Conflicts of the Clergy. New York: Thomas Nelson \& Sons, 1963.

Carter, John D., and Bruce Narramore. The Integration of Psychology and Theology. Grand Rapids, MI: Zondervan Publishing House, 1979.

Chen, Peter S. J., Eddie C. Y. Duo, and Betty Janice Chung. The Dilemma of Parenthood. Singapore: Koon Wah Printing, 1982 .

Clements, William M. Care and Counseling of the Aging. Philadelphia: Fortress Press, 1973.

Clifford, Richard J., and John J. Collins. Creation in the Biblical Traditions. Washington, DC: The Catholic Biblical Association of America, 1972 .

Clinebell, Howard J., Jr. Basic Types of Pastoral Counseling. Nashville: Abingdon Press, 1966.

Cobb, Jr., John B. Theology and Pastoral Care. Philadelphia: Fortress Press, 1979. 
Collins, Gary R. Christian Counselling--A Comprehensive Guide. Dallas: Word Publishing, 1988.

Cook, J. Keith, and Lee C. Moorehead, Six Stages of a Pastor's Life. Nashville: Abingdon Press, 1990.

Corsini, Raymond J., and Contributors. Current Psychotherapies. Itasca, IL: F. E. Peacock Publishers, 1984 .

Cullmann, Oscar. Immortality of the Soul or Resurrection of the Dead? New York: Macmillan Company, 1958.

- Salvation History. London: SCM Press, 1967.

Damsteegt, P. Gerard. Seventh-day Adventist Believe. . . A Biblical Exposition of 27 Fundamental Doctrines. Hagerstown, MD: Review and Herald Publishing Association, 1988.

Davis, Kathleen Ogden, "Working with Clinical Materials." In The Supervision of Pastoral Care. Louisville, KY: Westminster/John Knox Press, 1989.

Droege, Thomas A. The Faith Factor in Healing.

Philadelphia: Trinity Press International, 1991.

Ebon, Martin. "Bishop Pike's Seance." In Communicating with the Dead. New York: New American Library, 1968.

Eder, Matthias. Chinese Religion. Tokyo: Asian Folklore Studies, 1973.

Erikson, Erik. The Life Cycle Completed. New York: W. W. Norton, 1982 .

Erickson, Millard J. Christian Theology. Grand Rapids, MI : Baker Book House, 1985.

- Systematic Theology. Grand Rapids, MI: Baker Book House, 1985.

Estadt, Barry K., ed. The Art of Clinical Supervision. New York: Paulist Press, 1987.

Fairbank, John C. Chinese Thoughts and Institutions. Chicago, IL: The University of Chicago, 1957.

Fernandez, Gil G. Light Dawns over Asia. Cavite, Philippines: International Institute of Adventist Studies, 1990. 
Foster, Richard J. Celebration of Discipline. San Francisco, CA: Harper and Row, 1988.

Froom, LeRoy Edwin. The Coming of the Comforter. South Bend, IN: Review and Herald Publishing Association, 1928 .

Gerkin, Charles V. The Living Human Document. Nashville: Abingdon Press, 1984.

Goh Keng Swee. The Economics of Modernization and Other Essays. Singapore: Shing Loong Press, 1972.

Gratton, Carolyn. The Art of Spiritual Guidance. New York: Crossroad Publishing Company, 1993.

Grubbs, Dwight L. Beginning: Spiritual Formation for Leaders. Lima, OH: Fairway Press, 1994.

Hall, Charles E. Head and Heart. Decatur, GA: Association of Clinical Pastoral Education, 1992.

Harris, J. Gordon. Biblical Perspectives on Aging. Philadelphia: Fortress Press, 1987.

Hinton, Keith. Growing Churches--Singapore Style. Singapore: Hiap Seng Press, 1985.

Holmes, C. Raymond. The Last Word. Berrien Springs, MI: Andrews University Press, 1987.

Jackson, Edgar N. "Grief." In Concerning Death: A Practical Guide for the Living. Boston: Beacon Press, 1974.

Jensen, Mark. "Life Histories and Narrative Theology." The Supervision of Pastoral Care. Louisville, KY: Westminster/John Knox Press, 1989.

Johnson, Christopher J., and Marsha G. McGee, eds. Encounter with Eternity: Religious View of Life after Death. New York: Philosophical Library, 1986.

Johnstone, Patrick. Operation. World. Grand Rapids, MI : Zondervan Publishing House, 1993.

Kübler-Ross, Elizabeth. On Death and Dying. New York: Macmillan Publishing Company, 1973.

Kwok, Pui-lan. Chinese women and Christianity. Atlanta, GA: Scholars Press, 1992. 
Linn, Matthew, Sheila Fabricant, and Dennis Linn. Healing the Eight Stages of Life. New York: Paulist Press, 1987 .

Lloyd, Ian, and Irene Hoe. Singapore from the Air. Singapore: Times Press, 1985.

Lutz, Robert R., and Bruce T. Taylor. Surviving in Ministry. New York: Integration Books, 1990.

Main, John. The Heart of Creation. New York: Crossroad Publishing Company, 1989.

Marshall, Catherine. The Prayer of Peter Marshall. New York: McGraw-Hill Book Company, 1954.

Mitchell, Kenneth R., and Herbert Anderson. All Our Losses, All Our Griefs. Philadelphia: Westminster Press, 1983 .

Naden, Roy C. Your Spiritual Gifts. Berrien Springs, MI: Instructional Product Development, 1989.

Nauhaus, Richard John. Freedom for Ministry. Grand Rapids, MI: William B. Eerdmans Publishing Company, 1992.

Nelson, Ethel R. Mysteries Confucius Couldn't Solve. Dunlap, TN: Read Books, 1986.

Niebuhr, H. Richard, Daniel Day Williams, and James $M$. Gustafson. The Advancement of Theological Education. New York: Harper \& Brothers, Publishers, 1957.

Nouwen, Henri J. M. Creative Ministry. Garden City, NY: Doubleday \& Company, 1971.

- The Living Reminder. San Francisco: Harper and Row Publishers, 1966.

Olsen, V. Norskov. Man, the Image of God. Hagerstown, MD: Review and Herald Publishing Association, 1988.

Oates, Wayne E. A Practical Handbook for Ministry. Louisville, KY: Westminster Press, 1992.

Pastoral Counseling in Grief and Separation.

Philadelphia: Fortress Press, 1980. - Your Particular Grief. Philadelphia: Westminster Press, 1981. 
O'Grady, John F. Disciples and Leaders. New York: Paulist Press, 1991 .

Oosterwal, Gottfried. "Adventist Mission Today." In Health Evangelism Study Guide. Siloam Springs, AR: Creation Enterprises International, 1991.

Pembroke, Neil. Christian Perspective on Human Development. Grand Rapids, MI: Baker Book House, 1992.

Propst, L. Rebecca. Psychotherapy in a Reliqious Framework. Portland, OR: Human Science Press, 1988.

Provonsha, Jack. A Remnant in Crisis. Hagerstown, MD: Review and Herald Publishing Association, 1993.

Pruyser, Paul w. The Minister as a Diagnostician. Philadelphia: Westminster/John Knox Press, 1976.

Rice, Richard. The Reign of God. Berrien Springs, MI: Andrews University Press, 1985.

Richard, Timothy. Calendar of the Gods in China. Shanghai, China: Commercial Press, 1966.

Richardson, Alan. The Gospel According to Saint John. London: SCM Press, 1980.

Robinson, H. Wheeler. The Christian Doctrine of Man. Edinburgh: T. \& T. Clark, 1926.

Rupp, Joyce. May I Have This Dance? Notre Dame, IN: Ave Maria Press, 1993.

Schneider, John. Stress, Loss, and Grief. Baltimore, MD: University Park Press, 1984.

Schoun, Benjamin D. Helping Pastors Cope. Berrien Springs, MI: Andrews University Press, 1981.

Schweitzer, Albert. Reverence for Life. New York: Harper and Row, 1969.

Seventh-day Adventist Theological Seminary Bulletin, 19951996.

Shostrom, Everett L., and Dan Montgomery. Healing Love. Nashville: Abingdon Press, 1978.

Smith, D. Howard. Chinese Religion. London: Trinity Press, 1968 . 
Soothhill, William E. The Analects of Confucius. 2d ed. New York: Paragon Book Reprint Corp., 1968.

Stein, Murray. Jung's Treatment of Christianity. Wilmette, IL: Chiron Publications, 1985.

Steere, David A., ed. The Supervision of Pastoral Care. Louisville, KY: Westminster/John Knox Press, 1984.

Taylor, June Filkin. But for Our Grief. New York: A. J. Holman Co., 1977.

Thompson, Laurence G. The Chinese Way in Religion. Encino \& Belmont, CA: Dickinson Publishing Company, 1973.

Thomson, James. Seasons. New York: D. Appleton and Company, 1870 .

Tiller, Darryl J. "The Self as Instrument." In The Supervision of Pastoral Care. Louisville, KY: Westminster/John Knox Press, 1989.

"The Relation of Religion and Health." In Healing: Human and Divine. New York: Association Press, 1957.

Underwood, Ralph L. Empathy and Confrontation in Pastoral Care. Philadelphia: Fortress Press, 1985.

White, Arthur L. The Lonely Years: 1876-1891. Vol. 3 of Ellen G. White. Washington, DC: Review and Herald Publishing Association, 1981-1986.

White, Ellen G. The Acts of the Apostles. Mountain View, CA: Pacific Press, 1963.

- Christ's Object Lessons. Washington, DC: Review and Herald Publishing Association, 1941.

Conflict and Courage. Mountain View, CA: Pacific Press Publishing Association, 1965.

- Desire of Ages. Washington, DC: Review and Herald Publishing Association, 1964.

Education. Mountain View, CA: Pacific Press Publishing Association, 1952.

- Gospel Workers. Washington, DC: Review and Herald Publishing Association, 1958. 
- Great Controversy. Washington, DC: Review and Herald Publishing Association, 1958.

- Medical Ministry. Mountain View, CA: Pacific

Press Publishing Association, 1952.

- Ministry of Healing. Washington, DC: Review and Herald Publishing Association, 1958.

- Thoughts from the Mount of Blessing. Mountain

View, CA: Pacific Press Publishing Association, 1956.

Whitehead, James D., and Evelyn Eaton Whitehead. Method in Ministry. Minneapolis, MN: Winston Press, 1980.

Whyte, Bob. Unfinished Encounter. Glasgow: William Collins Sons \& CO., 1988.

Williams, Daniel Day. The Minister and the Care of the Soul. New York: Harper \& Brothers Publishing Co., 1961 .

Williams, Donna Reilly, and JoAnn Sturzl. Grief Ministry. San Jose, CA: Resource Publications, 1992.

- Grief Ministry Facilitator's Guide. San Jose,

CA: Resource Publications, 1995.

Williams, Philip $w$. When a Loved One Dies. Minneapolis, MN: Augsburg Press, 1986.

Williamson, Clark M., and Ronald J. Allen. The Teaching Minister. Louisville, KY: Westminster/John Knox Press, 1991.

Wilson, Dick. The Future Role of Singapore. New York: Oxford University Press, 1972.

Wong, James. Singapore--A Church in the Midst of Social Changes. Singapore: Church Growth Study Center, 1973.

Yeagley, Larry. Grief Recovery. Muskegon, MI: Larry Yeagley, 1984 .

Periodicals and Compilations

Cheatham, Augustus W., ed. "Our Mission." Scope, 31, no. 2 (Summer 1995): 41 .

Clinebel1, Howard J., Jr. "Pastoral, Psychology and Care in the People's Republic of China." The Journal of Clinical Pastoral Care 40, no. 4 (1986): 374. 
Davis, Kathleen Ogden. "Working with Clinical Material." Supervision of Pastoral Care. Philadelphia:

Westminster/John Knox Press, 1989.

Editor. "Statement III--Care for God's Creation" and "Statement IV--Care for the Dying." Ministry, May, $1993,24$.

Fanwar, Wann M. "Update on Ministries Co-ordinating Committee." Adventist Crossroads, July-September, 1994,2 .

Hasel, Gerhard F. "Health and Healing in the old Testament." Andrews University Seminary Studies 21, no. 3 (1983): 192 .

Holmes, C. Raymond. "The Gospel of the Sanctuary." Adventists Affirm, Fall 1992, 51.

Holmes, T. H., and R. H. Rahe. "The Social Readjustment Rating Scale." Journal of Psychosomatic Research 11 (1967): 213 .

Hurst, David M. "The Role and Function of Clinical Pastoral Education (CPE)." Southeast Michigan Cluster News Release, September 25, 1992, 1 .

Jernigan, Homer L. "Aging in Traditional Chinese Society", Journal of Religious Gerontology 8 no. 3 (1992): 20.

- "Preface to a Research Project in Pastoral Counseling." The Journal of Pastoral Care 35, no. 2 $(1981): 78$.

"Bringing Together Psychology and Theology: Reflection on Ministering to the Bereaved." The Journal of Pastoral Care 30, no. 2 (June 1976): 88-102.

[Johnsson, William G.], editorial. Adventist Review, December 31, 1992, 13-15.

[Johnsson, William G.], editorial. Adventist Review, April $22,1993,7$.

Keidel, Keith W. "Cross-cultural Clinical Pastoral Training in Singapore." The Journal of Pastoral Care 27, no. 2 (1973): 114 .

Lee, Jung Young. "The Yin-Yang Way of Thinking." International Review of Missions 60 (1971): 362-366. 
Lee, Ki-Plin. "Coping with Grief and Loss Seminar." Adventist Crossroads, July-September 1992, 4.

. "Self-esteem Seminar." Adventist Crossroads, January-March 1992, 10.

Marx, M. B., Garity, T. F., and Bower, F. R. "The Influence of Recent Life Experience on Health of College Freshmen." Journal of Psychosomatic Research 19 $(1975): 91$.

Moyers, Bill. "Mind over Malady." Time, March 1, 1993: 44.

Oden, Thomas C. "Recovering Lost Identity." The Journal of Pastoral Care 34, no. 1 (1980): 4 .

Roberts, David E. "Tillich's Doctrine of Man." The Theology of Paul Tillich. New York: Macmillan Company, 1959 .

Sim, Chor-Kiat. "Pastoral Diagnosis of Patients with Disabilities." Journal of Religion in Disability and Rehabilitation 2, no. 3 (1995): 42-50.

Straits Times, August 30, 1995, 18.

[Tan, John K. E.], editorial, "Church Votes for New Direction." Adventist Crossroads, April-June 1994, 4.

Tillich, Paul. "The Theology of Pastoral Care." Pastoral Psychology 10, no. 97 (1959): 23.

White, Ellen G. "Diligence, a Necessary Qualification in the Minister." Advent Review and Sabbath Herald, Battle Creek, MI: Advent Review and Sabbath Herald, 1886 .

World Journal, April, 1992, 15.

\section{Dictionaries and Commentaries}

Adeney, Walter F. "Music in the Bounds of Law." The Expositor's Bible. Edited by W. Robertson Nicoll. New York: A. C. Armstrong and Son, 1908. 7: 381-383.

Advanced English-Chinese Pinyin Dictionary. Singapore: Tien Mah Litho Printing Company, Federal Publications, 1988. 
Alexander, William. "Harvest of the Vintage of the World." The Expositor's Bible Commentary. Edited by $w$.

Robertson Nicoll. New York: A. C. Armstrong and Son, 1908. $25: 252$.

"Lamb on the Mount Zion." The

Expositor's Bible Commentary. Edited by $W$. Robertson Nicoll. New York: A. C. Armstrong and Son, 1908. $25: 243$.

Campbell, Alastair V., ed. Dictionary of Pastoral Care. New York: Crossroad Publishing Company, 1987.

The Catholic Encyclopedia. New York: Robert Appleton Company, 1910. S.v. "dead."

Dods, Marcus. "The Creation." The Expositor's Bible Commentary. Edited by $W$. Robertson Nicoll. New York: A. C. Armstrong and Son, 1908. 1:6, 14 .

Ferguson, Sinclair B., and David F. Wright, New Dictionary of Theology. Downers Grove, IL: Inter-Varsity Press, 1978 .

Florell, J. L. "Interpersonal Teams and Relatonships." Dictionary of Pastoral Care and Counseling. Nashville: Abingdon Press, 1990. 593.

"God's People Follow the Lamb." SDA Bible Commentary. Edited by F. D. Nichol. Washington, DC: Review and Herald Association, 1953-1957. 7:978.

Hebrew and Chaldee Dictionary. Nashville: Thomas Nelson Publisher, 1974.

Hermann, Cremer, Biblio-theological Lexicon of New Testament Greek. Edinburgh: T. and T. Clark, 1880. S.v.

"Paraclete."

Holladay, William L. A Concise Hebrew and Aramaic Lexicon of the old Testament. Grand Rapids: Wm. B. Eerdmans, 1971. S.v. "bâsâr"; "ruwach."

Kastenbaum, Robert, and Beatrice Kastenbaum, eds. Encyclopedia of Death. Phoenix: Oryx Press, 1989.

Lampe, G. W. H. "Paraclete." The Interpreter's Dictionary of the Bible. Nashville: Abingdon Press, 1962. 3:654655 .

"Last Enemy." SDA Bible Commentary. Edited by F. D. Nichol. washington, DC: Review and Herald, 1957. 6:806. 
Maclaren, Alexander. "Psalm 23." The Expositor's Bible Commentary. Edited by $W$. Robertson Nicoll. New York: A. C. Armstrong and Son, 1908. 8:227.

"Psalm 103." The Expositor's Bible Commentary. Edited by $W$. Robertson Nicoll. New York: A. C. Armstrong and Son, 1908. 9:102.

Myers, A. C. "Bless." The International Standard Bible Encyclopedia. Grand Rapids, MI: Wm. B. Eerdmans Publishing Co., 1979-1988. 1: 523-524.

"Patience." SDA Bible Commentary. Edited by F. D. Nichol. Washington, DC: Review and Herald Association, 19531957. $7: 832$.

Puff, R. E., "Emotional Development." Dictionary of Pastoral Care and Counseling. Edited by Rodney J. Hunger. Nashville: Abingdon Press, 1990. 352-354.

"Revelation." SDA Bible Commentary. Edited by F. D. Nichol. Washington DC: Review and Herald, 1957. 7: 988.

Schwab, Patty Ann. "A Brief Look at Weimar Institute." M.A. thesis, Andrews University, 1981.

Straatmeyer, A. J. "Theories of Psychpathlogy." Dictionary of Pastoral Care and Counseling. Edited by Rodney $\mathrm{J}$. Hunter. Nashville: Abingdon Press, 1990. 1011.

Switzer, D. K. "Grief and Loss." Dictionary of Pastoral Care and Counseling. Nashville: Abingdon Press, 1990. 472 .

Tenny, C. "The Gospel of John." The Expositor's Bible Commentary. Grand Rapids, MI: Zondervan Publishing House, 1981. 9:146.

Thayer, Joseph Henry. "Lupe." Greek English Lexicon of the New Testament. Chicago: American Book Company, 1881.

Thornton, E. E. "Pastoral Identity." Dictionary of Pastoral Care and Counseling. Edited by Rodney J. Hunter. Nashville: Abingdon Press, 1990. 567.

Toner, P. J. "Dead." The Catholic Encyclopedia. Edited by Charles G. Herbermann. New York: Robert Appleton Company, 1910, 4: 653 .

Nelson, Dwight. "Color Me Green." Sermon presented on April 3, 1993 at Pioneer Memorial Church, Berrien Springs, MI. 
Liu, Charles M. "A Spiritual Model for Recovery of Pastors' Suffering Burnout." D.Min. project report, Andrews University, 1991.

PC Globe. Tempe, AZ, 1993. 


\section{VITA}

\section{PERSONAL PARTICULARS}

Name:

Chor-Kiat Sim

Marital Status: Married (Children: 3 daughters)

Spouse:

Winnie

\section{ACADEMIC QUALIFICATIONS}

D Min Graduate

D Min Candidate

CPE Certificate

M Div

M A (Religion)

B Th (Theology)
Andrews University

Andrews University

(Advanced)

SDA Theological Seminary, Far East

SDA Theological Seminary, Far East

Southeast Asia Union College
1996

1993-1995

1993

1986

1980

1972

\section{CAREER HISTORY}

President

Secretary-treasurer Ministerial Sec.

Senior Pastor

Mission Director

Senior Pastor

Pastor/Director

Pastor

SDA Mission of Singapore

1989-1991

SDA Mission of Singapore

1987-1989

West Malaysia Singapore Mission

1983-1987

West Malaysia Singapore Mission

1983-1987

West Malaysia Singapore Mission

$1980-1983$

Southeast Asia Union College Ch.

$1976-1980$

Sarawak SDA Mission

1973-1975

West Malaysia Singapore Mission

1972-1973

\section{OTHER VOCATIONAL EXPERIENCES}

Supervisory Trainee Methodist Hospital, Indianapolis

Resident Chaplain

Howard Community Hospital

Resident Chaplain

Saint Joseph's Medical Center

Associate Chaplain

Memorial Hospital, South Bend

Chairman

Southeast Asia Union College

1991

Guest Lecturer

1988-1990

1980

\section{CREDENTIALS AND CERTIFICATES}

Denominational Endorsement

Clinical Pastoral Care Certificate

Sep. 30, 1993

Ministerial Ordination Credential

\section{PROFESSIONAL MEMBERSHIP}

Clinical Member of Association of CPE

Chaplain Associate of College of Chaplains 